University of Louisville

ThinkIR: The University of Louisville's Institutional Repository

Electronic Theses and Dissertations

$5-2007$

\title{
"The Union as it was and the Constitution as it is" : Unionism and emancipation in Civil War era Kentucky.
}

Jacob F. Lee 1982-

University of Louisville

Follow this and additional works at: https://ir.library.louisville.edu/etd

\section{Recommended Citation}

Lee, Jacob F. 1982-, "'The Union as it was and the Constitution as it is" : Unionism and emancipation in Civil War era Kentucky." (2007). Electronic Theses and Dissertations. Paper 807.

https://doi.org/10.18297/etd/807

This Master's Thesis is brought to you for free and open access by ThinkIR: The University of Louisville's Institutional Repository. It has been accepted for inclusion in Electronic Theses and Dissertations by an authorized administrator of ThinkIR: The University of Louisville's Institutional Repository. This title appears here courtesy of the author, who has retained all other copyrights. For more information, please contact thinkir@louisville.edu. 


\title{
"THE UNION AS IT WAS AND THE CONSTITUTION AS IT IS": UNIONISM AND EMANCIPATION IN CIVIL WAR ERA KENTUCKY
}

\author{
By \\ Jacob F. Lee \\ B.A., University of Louisville, 2005

\begin{abstract}
A Thesis
Submitted to the Faculty of the

Graduate School of the University of Louisville

in Partial Fulfillment of the Requirements

for the Degree of
\end{abstract} \\ Master of Arts \\ Department of History \\ University of Louisville \\ Louisville, Kentucky
}

May 2007 
Copyright 2007 by Jacob F. Lee

All rights reserved 


\title{
"THE UNION AS IT WAS AND THE CONSTITUTION AS IT IS": UNIONISM AND EMANCIPATION IN CIVIL WAR ERA KENTUCKY
}

\author{
By \\ Jacob F. Lee \\ B.A., University of Louisville, 2005
}

A Thesis Approved on

March 22, 2007

By the following Thesis Committee:

Thesis Director 
Turning and turning in the widening gyre

The falcon cannot hear the falconer; Things fall apart; the centre cannot hold

W. B. Yeats, "The Second Coming"1

${ }^{1}$ W. B. Yeats, "The Second Coming," in The Collected Poems of W. B. Yeats, Definitive Edition, with Author's Final Revisions (New York: The Macmillan Company, 1956), 184. 


\section{ACKNOWLEDGMENTS}

Like all historians, I owe a significant debt to a number of people. First, I would like to thank my professors. Dr. Thomas C. Mackey, who chaired my thesis committee, has mentored me since I was an undergraduate. He kept me on track while writing this thesis, and throughout the process, he offered countless suggestions that improved my research and writing skills. Dr. A. Glenn Crothers also deserves thanks both for serving on my thesis committee and for his guidance throughout my time as a graduate student. Because of his encouragement and suggestions, a paper written for one of his classes became my first published article. Dr. Jasmine Farrier of the Department of Political Science also sat on my committee, and her comments at the defense expanded my understanding of the implications of my research.

My fellow graduate students are also deserving of thanks. In sharing seminar rooms with me, they have introduced numerous ideas and perspectives that have improved the way I think about history. Matt Stanley, as a fellow student and co-worker, earned specific recognition. Matt and I commiserated while we were both writing our theses, and although our mutual love of baseball hampered the thesis process more than it helped, it provided countless hours of entertainment and debate.

My colleagues, past and present, at The Filson Historical Society have also supported me while working on this thesis. Jim Holmberg allowed me to take the time I needed to research and write. Noah Huffman, Elizabeth Kissack, Suzanne Maggard, 
Becky Rice, Mike Veach, and Robin Wallace all assisted me in various ways. I also need to thank The Filson's volunteers, particularly Joan Rapp, who brought to my attention countless documents which I may have missed otherwise.

Finally and most importantly, I need to thank my family, who supported me while I was sequestered in the nineteenth century. My parents have always encouraged me in everything I have done, and their support made it possible me to get to this point. My wife, Suzanne, put up with a distracted husband and endless discussion of Civil War era Kentucky. Without her support and reassurance, I would probably still be writing, and the finished product would surely be worse. 


\section{ABSTRACT \\ "THE UNION AS IT WAS AND THE CONSTITUTION AS IT IS": UNIONISM AND EMANCIPATION IN \\ CIVIL WAR ERA KENTUCKY}

JACOB F. LEE

MAY 12, 2007

In his 1926 study of the Civil War era in Kentucky, southern historian E. Merton Coulter repeated the old saying that Kentucky was the only state to secede after Appomattox. In an over-simplification of the process, most historians have seen harsh Union military policy as the root of Kentucky's ideological shift. However, in reading letters, diaries, and speeches written by Kentuckians during the Civil War, it becomes obvious that while Kentuckians were aware of and concerned about military policy, they were more alarmed by emancipation as a Union war goal. This thesis argues that emancipation and the subsequent enlistment of black troops contributed to Kentucky's adoption of a southern identity. Because of emancipation, many Kentuckians saw themselves as more akin to their fellow slaveholders in the South than to those northerners who had fought beside them in the Union army for four years. 


\section{TABLE OF CONTENTS}

PAGE

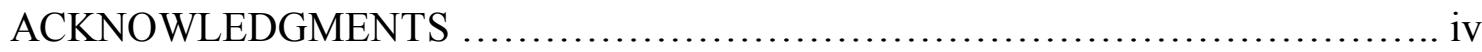

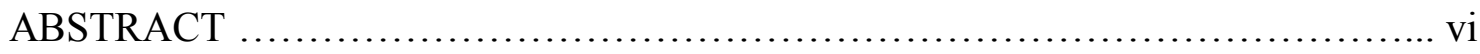

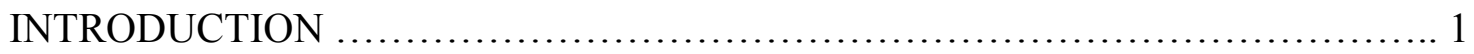

CHAPTER ONE: THE UNIONIST RESPONSE TO EMANCIPATION ………......... 12

CHAPTER TWO: THE CONSTITUTIONAL RESPONSE TO EMANCIPATION ... 37

CHAPTER THREE: THE RACIAL RESPONSE TO EMANCIPATION ............. 56

CHAPTER FOUR: THE ECONOMIC RESPONSE TO EMANCIPATION ........... 76

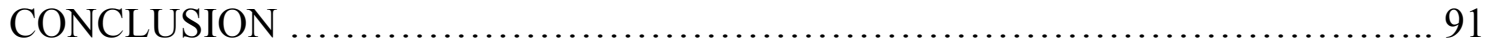

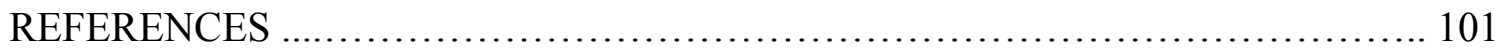

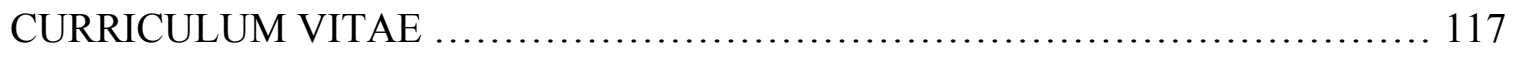




\section{INTRODUCTION}

In his 1926 study of the Civil War era in Kentucky, southern historian E. Merton Coulter repeated the old saying that Kentucky was the only state to secede after Appomattox. ${ }^{1}$ While the historical record demonstrates a move toward pro-southern sentiments in the state during the war, the reasons for this shift have been over-simplified. Most historians have seen harsh Union military policy as the root of Kentucky's ideological shift. While many Kentuckians, both loyal and not, suffered at the hands of Union soldiers, historians have ignored a more important factor in the state's changing loyalty. Caught between their loyalty to the Union and their cultural and economic ties to slavery, Civil War-era Kentuckians attempted to hold a middle ground in which they could defend both the Union and their domestic institutions. The Emancipation Proclamation altered the nature of the conflict, and the war for the Union also became a war for black freedom. Even through the ratification of the Thirteenth Amendment abolishing slavery in the United States, Kentuckians were unable to link the preservation of the Union with the demise of the peculiar institution. In the end, emancipation and the enlistment of black soldiers contributed to Kentucky's adoption of a southern identity.

While Coulter is the most well known historian to have argued that the Union military's treatment of Kentucky civilians resulted in the state's shift in sentiment, that explanation did not begin with him. In the late-nineteenth century, numerous Kentucky

\footnotetext{
${ }^{1}$ E. Merton Coulter, The Civil War and Readjustment in Kentucky (Chapel Hill: University of North Carolina Press, 1926; reprint, Gloucester, MA: Peter Smith, 1966), 439.
} 
historians offered that interpretation of events. ${ }^{2}$ Lewis and Richard H. Collins's Historical Sketches of Kentucky (1874) presented a chronology of the Civil War in Kentucky that emphasized military harshness. ${ }^{3}$ N. S. Shaler's Kentucky: A Pioneer Commonwealth (1884) also focused on the relationship between Kentucky and its "oppressors." While Shaler, a Unionist during the war, recognized the effects of emancipation and especially black enlistment, he overstated the importance of military presence on Kentucky's loyalty. Z. F. Smith's A History of Kentucky: From Its Earliest Discovery and Settlement, to the Present Date (1886) echoed Shaler to the point that much of his discussion of emancipation consisted of block quotes from Kentucky: A Pioneer Commonwealth. ${ }^{5}$ These few studies are representative of the interpretations put forward in other nineteenth century histories of Kentucky.

Based heavily on Collins's Historical Sketches, E. Merton Coulter's The Civil War and Readjustment in Kentucky (1926) was the first scholarly work on Kentucky during the war. ${ }^{6}$ The grandson of Confederate veterans and a proponent of the William A. Dunning school of Civil War historiography, Coulter used his work as a diatribe against Federal officials stationed in Kentucky. Coulter argued that Kentuckians tolerated the North because of economic ties, despite being socially and culturally

\footnotetext{
${ }^{2}$ One exception was Thomas Speed who emphasized Kentucky's continued Unionism and defended military policy in the state; Thomas Speed, The Union Cause in Kentucky, 1861-1865 (New York: G. B. Putnam's Sons, 1907).

${ }^{3}$ Lewis and Richard H. Collins, Collins' Historical Sketches of Kentucky, vol. 1 (Covington, KY: Collins \& Co., 1874; reprint, Louisville: John P. Morton \& Co., 1924), 85-159.

${ }^{4}$ N. S. Shaler, Kentucky: A Pioneer Commonwealth (Boston: Houghton Mifflin Co., 1884), 350.

${ }^{5}$ Z. F. Smith, The History of Kentucky: From Its Earliest Discovery and Settlement, to the Present Date (Louisville: Courier-Journal Job Printing Co., 1886).

${ }^{6}$ Coulter, The Civil War and Readjustment in Kentucky. John David Smith critiqued Coulter's interpretation, but he generously concluded that Coulter continued to offer much of value to historians; John David Smith, "E. Merton Coulter, the 'Dunning School,' and The Civil War and Readjustment in Kentucky," Register of the Kentucky Historical Society 86 (Spring 1988): 52-69. The year after Coulter published his work, Edward Conrad Smith came to many of the same conclusions; Smith, The Borderland in the Civil War (New York: Macmillan Company, 1927).
} 
southern and despising the "abolition Yankee." In a thesis accepted by most subsequent Kentucky historians, Coulter stated that the policies pursued by the Union army alienated the state and caused Kentuckians to shift their allegiances to the South. Moreover, Coulter emphasized the negative effects freedom had on Kentucky's black population and blamed them for post-war violence, sparking W. E. B. Du Bois's remark that Coulter believed "the Negro to be sub-human and congenitally unfitted for citizenship and suffrage." Coulter only briefly mentioned Kentucky’s reaction to emancipation and did not consider its long term effect on the state's allegiance to the Lincoln administration and the Union. Since its publication eighty years ago, The Civil War and Readjustment in Kentucky has remained the primary study of Kentucky during the Civil War. ${ }^{9}$

Only one historian has made a significant rebuttal to Coulter. In his 1969 article, “Kentucky: 'Pariah Among the Elect',' Ross A. Webb argued that Kentucky only became anti-administration rather than anti-Union. ${ }^{10}$ Webb helpfully differentiated between Kentucky's pro-southern and pro-Confederate sympathies. Although Webb made reference to Kentucky's reaction to emancipation, he agreed with Coulter, "A greater source of antagonism toward the federal government was the imposition of martial law upon Kentucky, under Brigadier General Jeremiah T. Boyle." ${ }^{11}$ Webb

\footnotetext{
${ }^{7}$ Coulter, The Civil War and Readjustment in Kentucky, 17.

${ }^{8}$ W. E. Burghardt Du Bois, Black Reconstruction: An Essay Toward a History of the Part which Black Folk Played in the Attempt to Reconstruct Democracy in America, 1860-1880 (New York: Russell \& Russell, 1935), 731. Du Bois includes Coulter in a list of historians who fall into the Dunning School. ${ }^{9}$ See also Lowell H. Harrison's short work, The Civil War in Kentucky (Lexington: University Press of Kentucky, 1975). While Harrison's overall interpretation improves on Coulter, the book's brevity undermines its overall success.

${ }^{10}$ Ross A. Webb, "Kentucky: 'Pariah Among the Elect'," in Radicalism, Racism, and Party Realignment: The Border States during Reconstruction, ed. Richard O. Curry (Baltimore: Johns Hopkins Press, 1969), 105-45. Ronald Ray Alexander also addresses emancipation as one of several factors in the ideological shift in Kentucky's Bluegrass region.; Alexander, "The Civil War in Central Kentucky, 1861-1865" (Ph.D. dissertation, University of Kentucky, 1976), especially 150-92.

${ }^{11}$ Webb, "Kentucky," 109.
} 
furthered his arguments about Kentucky's allegiance in the early sections of his book Kentucky in the Reconstruction Era (1979). ${ }^{12}$

Recent analyses of the state in the Civil War era have been brief and have taken few exceptions to Coulter's interpretation. One study that has expanded upon Coulter is Charles E. Yonkers's “The Civil War Transformation of George W. Smith: How a Western Kentucky Farmer Evolved from Unionist Whig to Pro-Southern Democrat." Although not designed to refute Coulter, Yonkers presented a more nuanced view of shifting loyalties in Kentucky. ${ }^{13}$ Smith, who lived in Henderson County, Kentucky, turned against the Union because of a combination of mistreatment at the hands of Union soldiers and emancipation policy. While Yonkers correctly argued that Smith's shift was representative, his focus was not wide enough to support the claim that Smith's reasons for switching sides were similar to those of other Kentuckians. Like Shaler, Yonkers recognized that emancipation had an effect on Kentucky Unionists but did not emphasize it sufficiently.

\section{Benjamin Franklin Cooling's Fort Donelson's Legacy: War and Society in}

Kentucky and Tennessee, 1862-1863 (1997) is another study that improved upon Coulter's analysis. ${ }^{14}$ Although Cooling's primary interest was guerrilla activity and the move toward "hard war," he discussed some aspects of social change in Kentucky, particularly in the state's western counties. One way in which Cooling expanded upon The Civil War and Readjustment in Kentucky was his recognition of disloyal segments of

\footnotetext{
${ }^{12}$ Ross A. Webb, Kentucky in the Reconstruction Era (Lexington: University Press of Kentucky, 1979).

${ }^{13}$ Charles E. Yonkers, "The Civil War Transformation of George W. Smith: How a Western Kentucky Farmer Evolved from Unionist Whig to Pro-Southern Democrat," Register of the Kentucky Historical Society 103 (Autumn 2005): 661-690.

${ }^{14}$ Benjamin Franklin Cooling, Fort Donelson's Legacy: War and Society in Kentucky and Tennessee, 1862-1863 (Knoxville: University of Tennessee Press, 1997).
} 
the civilian population. Rather than portraying Union policy toward civilians as the persecution of loyal Kentuckians, Cooling showed that Federal commanders faced a very real threat from Confederate sympathizers and the guerrillas they supported. Like Ross Webb, Cooling acknowledged Kentucky's negative reaction to emancipation, but he continued Coulter's argument that military mistreatment of civilians was the primary factor in Kentucky's changing allegiance.

The historiography also includes two books concerning Kentucky's blacks during the war. Both Victor B. Howard's Black Liberation in Kentucky: Emancipation and Freedom, 1862-1884 (1983) and Marion B. Lucas's A History of Blacks in Kentucky: From Slavery to Segregation, 1760-1891 (1992) discuss white reaction to emancipation, but their emphasis is on its effects on blacks. ${ }^{15}$ Howard's work was the first book-length study of emancipation in Kentucky. Although it provided useful information about Kentucky's black population during the period, Black Liberation in Kentucky was more descriptive than analytical, which hampered its overall success as a book. Lucas's work is the superior of the two, and even though it only devoted a little more than a chapter to the Civil War era, it offered a much richer explanation than Howard of how the war affected blacks. While both works, especially Lucas's, made contributions to a fuller understanding of the Civil War in Kentucky, their goals in writing did not include explaining the state's ideological shift and neither attempted to refute Coulter's thesis. The best synopsis of emancipation in Kentucky comes in The Destruction of Slavery

\footnotetext{
${ }^{15}$ Victor B. Howard, Black Liberation in Kentucky: Emancipation and Freedom, 1862-1884 (Lexington: University Press of Kentucky, 1983); Marion B. Lucas, A History of Blacks in Kentucky, vol. 1, From Slavery to Segregation, 1760-1891 (Frankfort: Kentucky Historical Society, 1992). Darrell E. Bigham also studied black life following emancipation, but his emphasis was on the postbellum period rather than the process of and reaction to liberation; Bigham, On Jordan's Banks: Emancipation and Its Aftermath in the Ohio River Valley (Lexington: University Press of Kentucky, 2006).
} 
(1985), part of the series, Freedom: A Documentary History of Emancipation, 18611867. ${ }^{16}$ In the essay on emancipation in Kentucky, Ira Berlin and his co-editors discussed the difficulties Kentucky faced in remaining both pro-Union and proslavery.

The single best study of white Kentucky's reaction to emancipation and black enlistment is John David Smith's 1974 article, “The Recruitment of Negro Soldiers in Kentucky, 1863-1865."17 Smith's article is flawed in that he did not push his research into a strong analysis. However, Smith integrated public policy, white reaction, and the black experience into a coherent narrative of this key period in Kentucky's transition away from Unionism. While he was not explicit about shifting loyalties, he demonstrated the extent to which Kentuckians opposed the use of black soldiers. Also useful is the essay on black enlistment in the Border States in The Black Military Experience (1982) volume of Freedom. ${ }^{18}$ In the section on Kentucky, the editors argue that black enlistment marked the beginning of the end for slavery in the Commonwealth.

In general, Civil War historians ignore Kentucky, because Kentucky fell in the borderland between North and South. Scholars who study the North during the Civil War can avoid Kentucky because it was more representative of the South. Likewise, historians of the Confederacy rightly exclude Kentucky because it remained in the Union. As a result, Kentucky's Civil War past has been understudied. While Civil War historiography in general has moved beyond the Dunning school, few studies of

\footnotetext{
${ }^{16}$ Ira Berlin, et al., eds., Freedom: A Documentary History of Emancipation, 1861-1867, Series I, vol. 1, The Destruction of Slavery (Cambridge: Cambridge University Pres, 1985), 493-518.

${ }^{17}$ John David Smith, "The Recruitment of Negro Soldiers in Kentucky, 1863-1865," Register of the Kentucky Historical Society 72 (Oct. 1974): 364-90. See also John W. Blassingame, "The Recruitment of Colored Troops in Kentucky, Maryland, and Missouri, 1863-1865," The Historian 29 (August 1967): 53345.

${ }^{18}$ Ira Berlin, Joseph P. Reidy, Leslie S. Rowland, eds. Freedom: A Documentary History of Emancipation, 1861-1867, Series II, The Black Military Experience (Cambridge: Cambridge University Press, 1982), 19196.
} 
Kentucky have advanced beyond Coulter. The literature on Kentucky during the Civil War remains mired in numerous misunderstandings about the state, particularly the notion that loyal Kentucky turned against the Union because of their persecution at the hands of the Union military.

Still, Coulter was not completely wrong in his analysis of Civil War Kentucky. Kentuckians did suffer during the war. Numerous examples can be found to support Coulter's thesis that the federal military abused Kentucky civilians. However, the military's treatment of Kentuckians was the sole, or even the primary, cause of their ideological shift. In reading letters, diaries, and speeches written by Kentuckians during the Civil War, it becomes obvious that while Kentuckians were aware of and concerned about military policy, they were more alarmed by emancipation as a Union war goal. This thesis argues that emancipation and the subsequent enlistment of black troops contributed to Kentucky's adoption of a southern identity. While most Kentucky Unionists did not become pro-Confederate, many did become pro-southern. While it is difficult to think of the South in the early 1860 s without thinking of the Confederacy, many Kentuckians in the era did just that. While Kentucky was politically loyal to the Union, Kentucky culture and society resembled that of the disloyal South than that of their northern allies. As a result, Kentuckians were pro-southern culturally and socially, while never seceding or following the political lead of the Confederate South. However, because of federal emancipation policy, loyal Kentuckians, like disloyal southerners, lost their slaves and by the end of the war, they believed themselves to be in a situation similar to that of the former Confederates. As a result, Kentuckians saw themselves as 
more akin to their fellow slaveholders in the South than to the northerners who had fought beside them in the Union army for four years.

The first chapter of this thesis provides a narrative of Kentucky's reaction to emancipation policy from John C. Frémont's proclamation in August 1861 through the Thirteenth Amendment which passed Congress in January 1865 and was ratified that December. In the four years from the Union army's first attack on slavery to the legal end of the institution, Kentucky became increasingly aware of and angry about federal emancipation policy. Appreciating the impact of black enlistment on white Kentuckians is central to understanding their reaction against emancipation. Some white residents of the state, although not many, were willing to accept the end of slavery as a casualty of war. Few, however, could accept the arming of black soldiers, which offended their cultural assumptions about race as well as terrified them with the possibility of servile insurrection.

Chapters Two through Four are thematic and each deals with a different aspect of Kentucky's response to emancipation. Chapter Two addresses the constitutional and to a lesser extent the legal arguments Kentuckians used in opposing federal policy. Often, they simply proclaimed that measures passed by Congress or imposed by President Lincoln were outside the powers delegated by the Constitution and thus unconstitutional. Other times they used states' rights rhetoric, arguing that it was improper for the federal government to make such sweeping decisions on matters best left to the states. Often, they put their criticisms in terms of property rights, stating that the government was not allowed to seize the property of United States citizens without due process. Some Kentuckians even went so far as to defend the rights of the disloyal southerners as well. 
Chapter Three analyzes the racial arguments adopted by Kentucky Unionists. Slave revolt was preeminent among their concerns. Drawing upon antebellum fears, Kentuckians often warned that emancipation, and especially the arming of black soldiers, would spark a race war. Kentuckians also charged abolitionists with promoting racial equality, and once black enlistment began, they argued that allowing African Americans to help preserve the Union would degrade whites and elevate blacks. Finally, Kentucky's proslavery Unionists argued that bondage was the best possible circumstance for blacks. Many Kentuckians believed that African Americans would be unable to support themselves in freedom because of their innate inferiority.

Chapter Four addresses Kentucky's economic concerns about emancipation. As soon as northern soldiers moved into Kentucky, slaves began flocking to Union camps, seeking refuge and freedom. The number of runaways only grew as the federal government made clear through legislation and presidential proclamation that bondsmen were not to be returned to their owners. Black flight greatly reduced the number of slaves held by Kentuckians, and slaveholders suffered economic repercussions caused by the loss of capital investment and an inadequate labor pool to sustain the state's agriculture.

To understand the effects of emancipation and the shifting sentiment in Kentucky, the state's geographic differences must be defined. Kentucky, like many states, was not politically or economically homogenous in the 1860s. The southwest part of Kentucky and the counties surrounding Lexington were more southern in their sympathies than the rest of the state. Eastern Kentucky, like most southern Appalachian areas, was predominantly Unionist, as were the river cities of Louisville and Covington. Much of 
the rest of the state from the edge of the Jackson Purchase to the Appalachian foothills had both Unionists and secessionists, although loyal men and women made up the majority. The economic impact of slavery is the key to understanding these regional differences. The slave population was greatest around Lexington and in the Jackson Purchase. ${ }^{19}$ As a result, these two areas were more heavily pro-Confederate than the rest of the state. On the other hand, eastern Kentuckians owned fewer slaves than any other region and was overwhelmingly Unionist. The areas along the Ohio River, particularly Louisville and the towns across from Cincinnati in northern Kentucky, had economic ties to the North and were less dependent on slave powered agriculture. Thus, they were two of the strongest Unionist areas of the state. Despite the regional differences in Kentucky, the state as a whole rejected federal plans for emancipation.

Kentucky failed in its attempts to maintain both the Union and slavery, and as a result, many of the state's Unionists found themselves in sympathy with the defeated Confederacy. While the military treatment of civilians played a role in the Kentucky's shift toward a pro-South sentiment, historians have overstated its importance for more than one hundred years. Instead, Emancipation is the key to understanding the state's changing allegiances. By 1862, Kentucky's northern allies could not abide the continued existence of human bondage in the South. Yet, while Kentuckians continued to hope for the perpetuation of slavery in their state if not in the South as a whole. From the Confiscation Acts through the Emancipation Proclamation and the founding of the United States Colored Troops, Kentuckians fought a losing battle against black freedom. The

\footnotetext{
${ }^{19}$ See statistics in Kenneth H. Williams and James Russell Harris, eds., "Kentucky in 1860: A Statistical Overview," Register of the Kentucky Historical Society 103 (Autumn 2005): 745
} 
ratification of the Thirteenth Amendment in December 1865 left them embittered over the demise of slavery. 


\section{CHAPTER I}

\section{THE UNIONIST RESPONSE TO EMANCIPATION}

From the beginning of the Civil War through the ratification of the Thirteenth Amendment in December 1865, Kentuckians opposed all federal efforts at emancipation. Indeed, the state's attachment to slavery was so strong that emancipation and the enlistment of black soldiers turned Kentuckians against the Lincoln administration and in some cases even the Union. Beginning with General John C. Frémont's 1861 proclamation freeing the slaves of Missouri rebels and continuing through the Confiscation Acts of 1861 and 1862, the 1863 Emancipation Proclamation and the enlistment of African American soldiers, this chapter traces the response of Kentuckians as they found themselves caught between their support for the Union and their desire to keep slaves. By the end of 1865 , federal emancipation policy pushed white Kentuckians to adopt the pro-southern ideology that defined the state for the rest of the nineteenth century.

United States Senator Garrett Davis is a prime example of a Kentuckian who began as a staunch Unionist but by war's end was a vocal critic of the Republican-led government. By 1864, Davis, whom historian E. Merton Coulter described as one who early in the war "allowed no one's zeal for the Union to exceed his own," turned against 
the Republican prosecution of the war, in part because of the changing federal war goals. ${ }^{1}$ In January of that year, Davis proposed eighteen resolutions in the Senate condemning the Lincoln government and recommending that "the people North and the people South ought to revolt against their war leaders and take this great matter into their own hands."2 Davis also became an outspoken opponent of every piece of antislavery legislation that came through the Senate. Although most Kentucky Unionists only turned against the Lincoln administration politically, some Kentuckians went so far as to support the Confederacy. A slaveholding Unionist from southwestern Kentucky, Ellen McGaughey Wallace opposed the federal government by late 1862 and what had become, she correctly perceived, a war for abolition. For much of the rest of the war, she condemned every move of the Lincoln administration and in April 1865, she lamented the surrender of Robert E. Lee at Appomattox. An avid diarist, Wallace spent much of the war recording her anti-Lincoln and anti-Union sentiments. ${ }^{3}$ Her shift in loyalty was not unique. Bevie Cain of Breckinridge County wrote in 1863, "Northerners are . . . for nothing but the abolition of slavery. I was for the Union myself until this fact became evident."4 Although Wallace and Cain represent an extreme view, many Kentuckians questioned and changed their loyalties because of emancipation.

In 1860 and 1861, most Kentuckians opposed both secession and abolition. The fact that the state first declared neutrality and then sided with the Union indicates their opposition to secession. Moreover, more than two-thirds of Kentucky's Civil War

\footnotetext{
${ }^{1}$ E. Merton Coulter, The Civil War and Readjustment in Kentucky (Chapel Hill: University of North Carolina Press, 1926; reprint, Gloucester, MA: Peter Smith, 1966), 268.

${ }^{2}$ Ibid., 208-9; Congressional Globe, $38^{\text {th }}$ Congress, $1^{\text {st }}$ session, 96-7.

${ }^{3}$ Ellen McGaughey Wallace Diary, 1861-1865, Wallace-Starling Family Diaries, Kentucky Historical Society, Frankfort, KY. Hereafter cited as Wallace Diary, [date], Wallace-Starling Family Diaries-KHS. ${ }^{4}$ Bevie Cain to James M. Davis, 10 January 1863, Bevie Cain Letters, Manuscripts, Kentucky Building, Western Kentucky University, Bowling Green, Ky.
} 
soldiers enlisted to protect the Union. ${ }^{5}$ Kentuckians had a long tradition of supporting the Union in the face of threats of secession from their fellow southerners. Most famously, Henry Clay sought compromise between North and South over Missouri in 1820, nullification in 1833 , and a number of issues in the early $1850 \mathrm{~s}^{6}{ }^{6}$ Clay's ideological descendant, John J. Crittenden, unsuccessfully attempted to prevent war during the secession winter with a series of compromise amendments to the Constitution. ${ }^{7}$ Throughout the antebellum period, Kentuckians showed that they were devoted to both the Union and slavery, and into the war years, they believed that they could support both simultaneously.

However, Kentucky Unionists were also advocates of slavery. As historian Harold D. Tallant argued, the state Constitution of 1850 effectively ended Kentucky's debate over slavery. ${ }^{8}$ After the passage of the new constitution, most Kentuckians believed that slavery had become a permanent fixture in the state. Emancipationist Cassius M. Clay moved on to national politics, and a proslavery mob ran abolitionist John G. Fee out of the state in January 1860. Others, like Robert J. Breckinridge, took the Constitution of 1850 as the final word on the matter and halted their efforts to end

\footnotetext{
${ }^{5}$ Historians debate the exact numbers for Kentuckians who served in the war.Ross A. Webb gives the numbers as 64,000 Union soldiers versus 30,000 Confederates. Lowell H. Harrison stated that Kentucky produced over 90,000 Union soldiers, which grows to over 100,000 if Home Guards are included, compared to somewhere between 25,000 and 40,000 Kentucky Confederates. Regardless, the figures are at least two-thirds Union and one-third Confederate. Ross A. Webb, Kentucky in the Reconstruction Era (Lexington: University Press of Kentucky, 1979), 9; Lowell H. Harrison, The Civil War in Kentucky (Lexington: University Press of Kentucky, 1975), 94-5.

${ }^{6}$ See David M. Potter, The Impending Crisis, 1848-1861, edited by Don E. Fehrenbacher (New York: Harper \& Row, 1976); William W. Freehling, The Road to Disunion, vol. 1, Secessionists at Bay, 17761854 (New York: Oxford University Press, 1990).

${ }^{7}$ Potter, The Impending Crisis, 531-2.

${ }^{8}$ Harrold D. Tallant, Evil Necessity: Slavery and Political Culture in Antebellum Kentucky (Lexington: University Press of Kentucky, 2003), 157-159. On the antislavery movement in Kentucky, see Tallant, Evil Necessity, and Stanley Harrold, The Abolitionists and the South, 1831-1861 (Lexington: University Press of Kentucky, 1995). For a brief, older study, see Lowell H. Harrison, The Antislavery Movement in Kentucky (Lexington: University Press of Kentucky, 1978).
} 
slavery. By the 1860 election of Lincoln and the 1861 firing on Fort Sumter, antislavery sentiment in Kentucky had, for all practical purposes, vanished. In September 1861, Joshua F. Speed wrote to Lincoln about the support for slavery in Kentucky, stating, "So fixed is public sentiment in this state against freeing negroes \& allowing negroes to be emancipated \& remain among us - That you had as well attack the freedom of worship in the north or the right of a parent to teach his child to read." "Unlike northerners who had the dual goal of preserving the Union and ending slavery, Kentuckians saw no connection between the two objectives.

Support for both the Union and slavery led Kentuckians to find a middle ground between the northern abolitionists and the southern fire-eaters. The conservative Unionism that they adopted was similar to the platform of Northern Democrats, who supported the war but opposed all efforts at abolition. Kentucky's dual opposition to secession and abolition was so representative of conservative Unionism that when the National Conservative Union Committee met in December 1863 they adopted the "Kentucky Platform," pledging opposition to radicals in both the North and the South. ${ }^{10}$ Indeed, many Kentucky Unionists loathed both secessionists and abolitionists. Senator Garrett Davis so despised both groups that he recommended the best way to end the war was to take one hundred secessionist leaders and one hundred abolitionist leaders and "hang them in pairs at the ends of the same rope." of Minnesota later pressed him on the issue, Davis replied, "[I]f I had the power to-night I

\footnotetext{
${ }^{9}$ Joshua F. Speed to Abraham Lincoln, 3 September 1861, Abraham Lincoln Papers, Library of Congress, Washington, DC. Available online at http://memory.loc.gov. Hereafter cited as Lincoln Papers-LC.

${ }^{10}$ National Conservative Union Committee to John B. Bruner, 9 November 1863, John B. Bruner Papers, The Filson Historical Society, Louisville, KY.

${ }^{11}$ Congressional Globe, $37^{\text {th }}$ Congress, $3^{\text {rd }}$ session, 797.
} 
would do the same, and among them I would hang the Senator from Minnesota."12 In 1864, writing from Bourbon County, L. G. Ray proclaimed, "It sounds very well to say, that after the rebellion is put down, we will turn our attention to the radical abolitionists \& settle them." ${ }^{\prime 3}$ Often, Kentucky’s congressional delegation blamed the war on fanatics in both the North and the South. Representative Aaron Harding made this point, condemning "the leading disunion abolitionists of the North" for their role in "plunging this great country into all the horrors of civil war and bloodshed.",14

Kentuckians also feared that emancipation would inhibit the war effort. Debating emancipation in Congress, Harding predicted, "Who ever lives to see that fearful and mad policy inaugurated, will see the sun of American liberty go down in clouds and darkness to rise no more."15 He continued, "The last hope of a restoration of the Union the last hope of free government on this continent - will then sink and utterly perish." Speaking about the Thirteenth Amendment three and a half years later, Representative Robert Mallory proclaimed, "You have changed your whole policy in regard to the war. You have converted it from a war to preserve the Union, as you acknowledge and boldly declare, into a war for the abolition of slavery, because you say it is the only way to preserve the Union." As a result, Mallory stated, "You have united the people of the southern States in solid phalanx and divided the people of the North, and alienated to a great extent the people of States who were almost undivided at the commencement of the war."16

\footnotetext{
${ }^{12}$ Congressional Globe, $38^{\text {th }}$ Congress, $1^{\text {st }}$ session, 3345.

${ }^{13}$ L.G. Ray to Brutus J. Clay, 23 February 1864, Clay Family Papers, Margaret I. King Library, University of Kentucky, Lexington, KY. Hereafter cited as Clay Family Papers-UK.

${ }^{14}$ Speech of Hon. A. Harding, of Kentucky . . December 17, 1861 (Washington, DC: Scammell \& Co. Printers, no date), 15.

${ }^{15}$ Ibid., 9 .

${ }^{16}$ Congressional Globe, $38^{\text {th }}$ Congress, $1{ }^{\text {st }}$ session, 2981.
} 
In 1861, Kentuckians contemplated secession, fearing the course the Republican administration might pursue regarding slavery. Although Kentucky chose to remain in the Union, federal officials realized the state's fragile loyalty. Throughout the early months of the war, Lincoln and others in Washington appreciated Kentucky's attachment to slavery. In August 1861, when General John C. Frémont issued his proclamation freeing the slaves of Missouri rebels, Unionists in Kentucky appealed to Lincoln, fearing that a delay in the president's condemnation would cause irreparable damage to the state's support for the administration. In September 1861, Joshua F. Speed, a stanch Kentucky Unionist and friend of Lincoln, discussed Frémont's proclamation with the president, writing, "I have just seen Fremonts proclamation - it will hurt us in Ky." 17 Two days later, Speed wrote that he had been so "distressed" about Frémont's "foolish proclamation" that he had been "unable to eat or sleep." 18 Speed believed that any move toward emancipation would "crush out every vestage of a union party" in Kentucky. Knowing Speed had the ear of the president, a group of Kentucky Unionists wrote him a one sentence telegram: "There is not a day to lose in disavowing emancipation or Kentucky is gone over the mill dam."19 With Kentucky on his mind, Lincoln ordered Frémont to revise his proclamation so that it was less offensive to Unionists in the Border States.

In December 1861, a subordinate once again undermined Lincoln's moderate course on emancipation when, in his annual report, Secretary of War Simon Cameron

\footnotetext{
${ }^{17}$ Joshua F. Speed to Abraham Lincoln, 1 September 1861, Abraham Lincoln Papers, Library of Congress, Washington, DC. Available online at http://memory.loc.gov. Hereafter cited as Lincoln Papers-LC.

${ }^{18}$ Joshua F. Speed to Abraham Lincoln, 3 September 1861, Lincoln Papers-LC.

${ }^{19}$ J. F. Bullitt, C. Ripley, and W. E. Hughes to Joshua F. Speed, 13 September 1861, Lincoln Papers-LC.
} 
urged emancipation and the recruitment of black soldiers. ${ }^{20}$ When the report came to his attention, Lincoln, well aware of the tenuous loyalty of the Border States, demanded that all of the copies be seized and that the offending language be removed. The Kentucky General Assembly went so far as to demand Cameron's removal as Secretary of War. ${ }^{21}$ At this point Lincoln publicly opposed emancipation, much less the arming of freedmen, but some Kentuckians believed the Secretary of War's report reflected Lincoln's sentiments. On December 15, Ellen McGaughey Wallace wrote, "This day President Lincoln's message has been received and filled the hearts of all loyal citizens with disappointment, shame and indignation, arming and emancipating the slaves seems to be contemplated ...."22 In general, however, Kentuckians received solace from Lincoln's condemnation of Cameron's report.

The period from December 1861 to September 1862 witnessed a number of sudden changes in federal policy toward slaves. By early 1862 , despite worries about the Border States, Lincoln believed his political support across the Union was strong enough to sustain adding emancipation as a war goal. ${ }^{23}$ On March 11, Congress passed, despite resistance from Kentucky's representatives, a resolution urging the government to instate a plan of compensated emancipation. By the summer of 1862, Lincoln was ready to approach the Border State, and in July, he offered the Border States a plan for gradual, compensated emancipation. Lincoln argued that emancipation in the Border States would

\footnotetext{
${ }^{20}$ The information regarding Cameron's annual report is compiled from the following books, Allen C. Guelzo, Lincoln's Emancipation Proclamation: The End of Slavery in America (New York: Simon \& Schuster, 2004), 70-1; Doris Kearns Goodwin, Team of Rivals: The Political Genius of Abraham Lincoln (New York: Simon \& Schuster, 2005), 404-5; Stephen B. Oates, With Malice Toward None: A Life of Abraham Lincoln (New York: Harper \& Row, 1977; paperback, HarperPerennial, 1994), 269.

${ }^{21}$ Coulter, The Civil War and Readjustment in Kentucky, 156.

${ }^{22}$ Ellen McGaughey Wallace Diary, 15 December 1861, Wallace-Starling Family Diaries-KHS.

${ }^{23}$ See discussion in Richard Carwardine, Lincoln: A Life of Purpose and Power (New York: Alfred A. Knopf, 2006), 190-248.
} 
end the Confederacy's hope of support from the loyal slaveholding states. ${ }^{24}$ By ending slavery along the border, the Confederacy would realize that it was on its own and would soon collapse. If the Border States did not accept compensation for their slaves, Lincoln warned, they would be left with nothing once the war destroyed the institution of slavery through "friction and abrasion." Moreover, Lincoln promised that the freedmen would be colonized in the Deep South. In response to Lincoln's proposal, seven Kentucky Congressmen and one Senator wrote to the president explaining that they opposed the measure for constitutional and financial reasons. ${ }^{25}$ They believed the president did not have the power to authorize such a measure and that the government could not provide the necessary funds. Even gradual emancipation complete with compensation and colonization was unappealing to the Kentuckians who expected to maintain their slave property in spite of the effects of the war.

The Confiscation Acts also proved to be a delicate issue in Kentucky. The First Confiscation Act of August 1861 generated some controversy in the state, but not to the extent of other measures. ${ }^{26}$ Tellingly, Kentucky rescinded its position of neutrality well after the passage of the First Confiscation Act. Some Unionists protested the law, but others saw it as a justifiable war measure. Kentuckian Joseph Holt explained that the state's loyal men had accepted the law because it limited confiscation to slaves employed in the Confederate war effort and did not give the confiscated chattel their freedom. ${ }^{27}$

\footnotetext{
${ }^{24}$ Abraham Lincoln, Address to Border State Representatives, 12 July 1862, Lincoln Papers-LC.

${ }^{25}$ Border State Congressmen to Abraham Lincoln, 14 July 1862, Lincoln Papers-LC. One Kentucky Representative, Samuel L. Casey, supported the measure; Border State Congressmen to Abraham Lincoln, 15 July 1862, Lincoln Papers-LC.

${ }^{26}$ For statements by Kentucky Congressmen about the bill, see Congressional Globe, $37^{\text {th }}$ Congress, $1^{\text {st }}$ Session, 410-15.

${ }^{27}$ Joseph Holt to Abraham Lincoln, 12 September 1861, Lincoln Papers-LC. Historian Silvana R. Siddali has argued that the First Confiscation Act did in fact free slaves despite the imprecise wording of the bill;
} 
Holt stated that Kentuckians recognized the Confiscation Act as part of Lincoln's “conservative policy ... upon this delicate \& perplexing question." On July 17, 1862, Congress passed the Second Confiscation Act. Unlike the first act, the second engendered strong opposition in Kentucky. The Louisville Daily Democrat, which had supported the First Confiscation Act, spoke out against the second because its provisions encouraged emancipation. ${ }^{28}$ On the floor of the Senate, Lazarus W. Powell of Kentucky stated that the bill would not "meet the approval of one man in five thousand in any slave State of the Union." 29 Powell also warned that the bill would make "many, now friendly, enemies to this Union. ${ }^{30}$ In the House of Representatives, John C. Crittenden condemned the act as unconstitutional and "perfectly fatal to this republic." ${ }^{31}$ When the final bill came to a vote in the House and the Senate, seven Kentucky representatives and both senators voted against the measure.

On the same day Congress passed the Second Confiscation Act, it also accepted a revised version of the Militia Act of 1795. The revision sanctioned the enlistment of black troops "for the purpose of constructing entrenchments, or performing camp service, or any other labor, or any military or naval purpose for which they may be found competent. ${ }^{, 32}$ Moreover, the act freed blacks who enlisted but still belonged to disloyal masters. In the Senate, Garrett Davis spoke out against the act stating that while he would welcome black laborers for the war effort he would never support the use of

Siddali, From Property to Person: Slavery and the Confiscation Acts, 1861-1862 (Baton Rouge: Louisiana State Press, 2005), 81-82.

${ }^{28}$ Siddali, From Property to Person, 134.

${ }^{29}$ Congressional Globe, $37^{\text {th }}$ Congress, $2^{\text {nd }}$ session, 2996.

${ }^{30}$ Lazarus W. Powell, Speech of Hon. L. W. Powell, of Kentucky, on the Bill to Confiscate the Property and Free the Slaves of Rebels (Washington, DC: L. Towers \& Co., 1862), 12.

${ }^{31}$ Congressional Globe, $37^{\text {th }}$ Congress, $2^{\text {nd }}$ session, 1802.

${ }^{32}$ Statutes at Large, 599. 
African American soldiers. ${ }^{33}$ He argued that the use of black troops degraded whites in the military, and he asserted that a thousand Kentuckians out of a thousand agreed with him. Kentucky Senator Lazarus W. Powell criticized the bill as an attack on private property, turning the army into a band of "national plunderers." 34 Powell warned that "all Christendom" would condemn the law as "harsh, brutal, and cruel." Despite the lamenting and hand-wringing of Kentucky's representatives, the bill passed both houses with little difficulty. ${ }^{35}$

On September 22, 1862, believing in the necessity of emancipation, Lincoln issued his preliminary Emancipation Proclamation. Kentuckians, particularly those in the Bluegrass, made little mention of the document. The Union victory at Antietam Creek in Maryland, which gave Lincoln the confidence to issue the proclamation, repulsed one part of a two-pronged Confederate offensive. As Lincoln made his announcement, the western Confederate army was moving through eastern Kentucky, and distracted white Kentuckians paid little attention to political statements from Washington. Although many of the state's residents later recorded their views on emancipation, in September and October 1862, most concerned themselves with the Confederate army. In western Kentucky, however, the Confederate threat was less worrisome, and Ellen Wallace wrote in her diary, "Lincoln's proclamation emancipating all the slaves is justly created great indignation." Wallace continued that the "wretch [Lincoln] ought to suffer all the torments that could be inflicted on him, body and soul. ${ }^{36}$ By December 1862, Wallace believed that Lincoln deserved impeachment and imprisonment in a dungeon for the rest

${ }^{33}$ Congressional Globe, $37^{\text {th }}$ Congress, $2^{\text {nd }}$ Session, 3204.

${ }^{34}$ Ibid., 3349.

${ }^{35}$ Guelzo, Lincoln's Emancipation Proclamation, 113.

${ }^{36}$ Wallace Diary, 29 September 1862, Wallace-Starling Family Diaries-KHS. 
of "his miserable life." ${ }^{37}$ Although she had been a strong Unionist through the first eighteen months of the war, Wallace, like many Kentuckians, turned against the Lincoln administration as emancipation became a war goal.

When the Confederate threat subsided, more Kentuckians registered their complaints about Lincoln's plan to emancipate southern slaves. In November, the editor of the Frankfort Tri-Weekly Commonwealth proclaimed that "the President's nigger proclamation ought to be shoved down his throat." ${ }^{38}$ On December 26, John B. Bibb of Frankfort wrote, "I think Mr. Lincoln is about to commit a great blunder. I do not think the proclamation will have the happy effect he anticipates, probably the contrary." 39 Although Bibb stated that he would voluntarily free his slaves if it would end the rebellion, he was part of a small minority willing to sacrifice the peculiar institution for the sake of the Union. By the end of 1862, Kentucky's opposition to the proclamation had reached such levels that military commanders in the state feared secession in the new year. On December 30, General Horatio G. Wright, commander of the Department of Ohio, wrote to General Henry W. Halleck about his concerns. ${ }^{40}$ Wright feared that when Lincoln issued his proclamation, the Kentucky legislature, with Governor James F. Robinson's approval, would pass an ordinance of secession. To counter any possible rebellious action Wright ordered additional units of artillery, cavalry, and infantry to

\footnotetext{
${ }^{37}$ Ibid., 13 December 1862.

${ }^{38}$ Frankfort Tri-Weekly Commonwealth, 19 November 1862, quoted in Lowell H. Harrison, Lincoln of Kentucky (Lexington: University Press of Kentucky, 2000), 233.

${ }^{39}$ John B. Bibb to Mary S. Payne, 26 December 1862, Lewis-Starling Collection, Manuscripts, Kentucky Building, Western Kentucky University, Bowling Green, KY. Hereafter cited as Lewis-Starling Collection-WKU.

${ }^{40}$ Horatio G. Wright to Henry W. Halleck, 30 December 1862, in War of the Rebellion: A Compilation of the Official Records of the Union and Confederate Armies (Washington, DC: Government Printing Office, 1900), Series I, vol. 20, part 2, 282. Hereafter cited as OR.
} 
report to Kentucky from Ohio and western Virginia. ${ }^{41}$ Although Wright overreacted, his concern indicates the extent to which Kentuckians disapproved of the measure.

Although he did not advocate secession as Wright expected, Governor Robinson issued a harsh rebuke of the Lincoln administration in his 1863 annual message to the legislature. Covering most of the arguments Kentuckians used to oppose emancipation, Robinson argued that "this monstrous doctrine" violated the constitutions of both Kentucky and the United States, complained that it would unify the South "into one burning mass of inextinguishable hate," and lamented the free blacks created by the order. $^{42}$ Robinson believed that the Union must be preserved but only within the bounds of the Constitution. The governor stated, "If military necessity is not to be measured by constitutional limits, we are no longer a free people." Robinson also feared that emancipation would reinforce Confederate suspicions of the dark intentions of the Republican administration and would crush any hope of restoring the Union. Finally, Robinson feared that the freedmen would rise up and slaughter the white population of the South. Even if by some chance servile insurrection was avoided, Robinson doubted blacks and whites could live together. The Kentucky legislature voted to send the President a copy of Robinson's anti-emancipation statements. ${ }^{43}$

Numerous Kentuckians echoed the governor's sentiments. In January, the editors of the Louisville Weekly Journal voiced the opinions of many across the state. ${ }^{44}$ Although believing the Emancipation Proclamation to be a "dead letter," the Journal condemned it as a "power for evil." The newspaper feared that it would strengthen the

\footnotetext{
${ }^{41}$ Horatio G. Wright to Gordon Granger, 31 December 1862, in $O R$, Series I, vol. 20, part 2, 287.

${ }^{42}$ Journal of the House of Representatives of the Commonwealth of Kentucky (Frankfort: John B. Major, 1863), 1122-27. Quotations from 1126.

${ }^{43}$ Ibid., 1126.

${ }^{44}$ Louisville Weekly Journal, 6 January 1863 ,
} 
Confederacy and tear apart the North, all without carrying out what it proposed. Even if they believed the proclamation was impotent, Kentuckians understood what it represented. On January 2, 1863, Louisvillian John F. Jefferson wrote, "Lincoln's emancipation proclamation ... shows beyond doubt that Lincoln is an abolitionist of the deepest dye. I unhesitatingly condemn this proclamation." ${ }^{45}$ John E. Records wrote to Kentucky legislator E. Hubbard Smith, stating, "I am for the Constitution, the Union, and the Enforcement of the laws. I am down on the Abolition-Republican rabble with all the energy I possess. ${ }^{, 46}$ Union soldier John T. Harrington remarked, "I enlisted to fight for the Union and the Constitution but Lincoln puts a different construction on things and now has us Union men fighting for his Abolition Platform and thus making us a hord [sic] of Subjugators, house burners, negro thieves, and devastators of private property." ${ }^{, 47}$ Kentucky slaves fled from their masters since the Union army first arrived in the state, and black flight increased once Lincoln issued the Emancipation Proclamation. The President's statements clarified Union policy toward runaways and gave African Americans more confidence that soldiers would not turn them away from their lines. Union soldiers, increasingly equating slaveholding with disloyalty, did little to dissuade blacks from seeking refuge with them. The troops often gave them shelter and prevented their re-enslavement. ${ }^{48}$

Kentucky slaveholders, on the other hand, did all they could to prevent escapes and to reclaim those who made it to Union lines. A common method of thwarting

\footnotetext{
${ }^{45}$ John F. Jefferson Diary, 2 January 1863, John F. Jefferson Papers, The Filson Historical Society, Louisville, KY.

${ }^{46}$ John E. Records to E. Hubbard Smith, 22 January 1863, E. Hubbard Smith Papers, The Filson Historical Society, Louisville, KY.

${ }^{47}$ John T. Harrington to "Dear Sister," 19 January 1863, John T. Harrington Letters, Kentucky Historical Society, Frankfort, KY.

${ }^{48}$ Ira Berlin, et al, eds., Freedom: A Documentary History of Emancipation, 1861-1867, Series I, vol. 1, The Destruction of Slavery (Cambridge: Cambridge University Press, 1985), 499-501.
} 
runaways was to arrest them. Under Kentucky law, captured fugitive slaves were advertised and if no one came forward to claim them, the sheriff sold them at auction. However, many of the African Americans arrested as runaways were actually freedmen who had fled the South after being emancipated by the Second Confiscation Act or Lincoln's proclamation. In October 1862, many soldiers in the invading Confederate army brought servants, many of whom were left behind as the rebels retreated. ${ }^{49}$ These former slaves had been freed under the Second Confiscation Act, but Kentuckians captured them and sold them back into slavery. In March 1863, the Kentucky General Assembly passed legislation forbidding freedmen from the entering the state. Those who were caught would be "disposed of as runaways." ${ }^{\circ 0}$ By April 1863, General Ambrose Burnside was so concerned about the enslavement of freedmen that he issued General Orders, No. 53, which forbade the practice. ${ }^{51}$ Yet, the re-enslavement did not stop. Amy Moore, a freedwoman from Alabama, informed the Freedmen's Bureau that in the summer of 1863, she, her mother, and three of her sisters were arrested in Louisville after leaving the Deep South. ${ }^{52}$ The Bullitt County sheriff imprisoned them and then auctioned them off.

Kentuckians also worked to recover slaves who flocked to military encampments. Smith D. Atkins, Colonel of the $92^{\text {nd }}$ Illinois Infantry, described slaveholders' efforts to reclaim contraband attached to his regiment. Atkins wrote, "At Winchester I was threatened by a mob, and some of the $14^{\text {th }} \mathrm{Ky}$. Infy. tried to take by force, servants from my lines, while marching along." As a result, his regiment thought it necessary to go

\footnotetext{
49 Ibid., 404-5.

${ }^{50}$ Acts of the General Assembly of the Commonwealth of Kentucky (Frankfort: John B. Major, 1863$), 366$.

${ }^{51}$ General Orders, No. 53, Department of the Ohio, 28 April 1863, in Ira Berlin, et al., eds., The Destruction of Slavery, 571-2.

${ }^{52}$ Affidavit of Amy Moore, 14? August 1865, in ibid., 567.
} 
through town "with bayonets fixed and guns loaded," in order to stave off attack. ${ }^{53}$ General Gordon Granger, commander of the Army of Kentucky, reported that he had received numerous complaints from Kentuckians whose slaves were protected by out of state regiments. ${ }^{54}$ Charles S. Rogers of the $10^{\text {th }}$ Kentucky Cavalry asked Granger for some assurance that his soldiers' slaves would be protected while they were off fighting the Confederates. ${ }^{55}$ The state's courts also worked to protect slave property, as judges indicted officers who commanded regiments that harbored fugitive slaves.

One of the more famous such incidents is the case of Judge George Robertson. In November 1862 , Robertson met with Colonel William L. Utley of the $22^{\text {nd }}$ Wisconsin Infantry to reclaim one of his slaves, a young male, who was in the Nicholasville camp of Utley's regiment. ${ }^{56}$ Although Utley did not forbid Robertson from taking the boy, he refused to deliver him to Robertson and did nothing to stop his men from interfering. When Robertson was unable to take the slave, he had Utley indicted for violating state laws regarding fugitive slaves. Both Utley and Robertson appealed to President Lincoln for aid. Lincoln refused to return the slave to Robertson, instead offering to pay the judge $\$ 500$ if he would turn the boy over to Utley. Robertson refused, hoping to test the constitutionality of the Emancipation Proclamation. What happened to the slave in question is unknown, but in 1871, the United States Circuit Court for the Eastern District of Wisconsin awarded $\$ 908.06$ to Robertson. ${ }^{57}$

Union commanders in state worked to alleviate strife between Union soldiers and Kentucky civilians. In the fall of 1862, General Jeremiah T. Boyle, commander of the

\footnotetext{
${ }^{53}$ Smith D. Atkins to B. H. Polk, 25 November 1862, in ibid., 535.

${ }^{54}$ Gordon Granger to Horatio G. Wright, 18 November 1862, in ibid., 544-5.

${ }^{55}$ Charles S. Rogers to Gordon Granger, 24? November 1862, in ibid., 534-5.

${ }^{56}$ Harrison, Lincoln of Kentucky, 233-5.

${ }^{57}$ Ibid., 235.
} 
District of Western Kentucky and a native Kentuckian, issued an order forbidding "negro slaves" from entering military camps and expelling those already in Union lines. ${ }^{58}$

Likewise, General Q. A. Gillmore, who headed the Army of Kentucky's Second

Division, forbade the presence of African Americans in the camps of his soldiers. ${ }^{59}$ The changing nature of the war, however, precluded continued preferential treatment for Kentucky slaveholders. By the summer of 1863, Union commanders in Kentucky fell in line with the policy laid out by the Lincoln administration and ordered the impressments of black laborers. ${ }^{60}$

Yet, nothing infuriated Kentuckians more than the enlistment of black troops. As early as 1861 , Kentucky's residents feared that the Lincoln administration would arm African Americans, both free and enslaved, as part of the war effort against the Confederacy. Kentuckians' criticisms of Secretary of War Cameron's 1861 annual report expressed their anxiety about the use of black soldiers and emancipation. ${ }^{61}$ The July 1862 Militia Act raised further fears, which the Emancipation Proclamation confirmed at the end of the year. Although Kentucky was at first exempted from black enlistment, it was not long before recruiters began operating in the state.

\section{In June 1863, Colonel James B. Fry, Provost-Marshal-General of the United} States Army, authorized the enlistment of Kentucky's free blacks but not the state's slaves, believing that to be less offensive to Kentuckians. However, he was mistaken; Kentuckians opposed the use of all black soldiers, not just former bondsmen. Brigadier General Jeremiah T. Boyle, a native Kentuckian and commanding officer of the state,

\footnotetext{
${ }^{58}$ General Orders, No. 2, District of Western Kentucky, 27 November 1862, in Berlin, et al., eds., The Destruction of Slavery, 549.

${ }^{59}$ General Orders, No. 9, Second Division, Army of Kentucky, 22 October 1862, in ibid., 551-2.

${ }^{60}$ General Orders, No. 41, District of Kentucky, 10 August 1863, in ibid., 585-6.

${ }^{61}$ Coulter, Civil War and Readjustment in Kentucky, 156.
} 
wrote to Fry warning him of his error. ${ }^{62}$ Boyle cautioned Fry that at most he would gain seven hundred black soldiers but he would lose ten thousand additional white recruits as he would "revolutionize the State." Moreover, Boyle believed that no "honest, loyal man in the State" was in favor of the measure and that the army would meet with "decided opposition.” Major General Ambrose E. Burnside, stationed in Cincinnati, also warned of the dangers of enlisting Kentucky's black population. In June 1863, he wrote to President Lincoln, "I sincerely hope the enrollment may be stopped." ${ }^{, 3}$ A brief cessation lasted six months.

Kentucky civilians, politicians, soldiers, and newspaper editors all condemned the federal plans for black enlistment even when their state was exempt. Their denunciations only increased as recruiters entered the state. In January 1864, Union recruiters began operating in Paducah. When he learned of black recruitment in southwestern Kentucky, Governor Bramlette wrote to President Lincoln condemning the action, arguing that the enlistment of freedmen in Kentucky, a loyal state, was illegal. "The rebellious States and districts," he continued, should be treated as "belligerants," not enjoying the rights and legal position of loyal states. In those areas, Bramlette believed, the federal government had the power to recruit black troops because of "the laws of Nations." However, Lincoln did not have the authority to recruit African Americans in loyal states as part of the militia. Bramlette believed that blacks did not meet the citizenship requirements to qualify for militia duty. However, his protest fell on deaf federal ears, and by March, recruiting stations had opened across the state. ${ }^{64}$

\footnotetext{
${ }^{62}$ Jeremiah T. Boyle to J. B. Fry, 25 June 1863, in OR, Series III, vol. 3, 416.

${ }^{63}$ Ambrose Burnside to Abraham Lincoln, 27 June 1863, in ibid., 419-20. Quotation from 420.

${ }^{64}$ Thomas E. Bramlette to Abraham Lincoln, 1 February 1864, Lincoln Papers-LC.
} 
Kentucky's Unionist newspapers too opposed the recruitment and use of black troops. ${ }^{65}$ Editors from Louisville, Lexington, Frankfort, and towns across the state all voiced their dissent. Newspaper editors George D. Prentice and Albert G. Hodges were both longtime advocates of the Union, but they condemned the Lincoln administration for its use of black soldiers. In the Louisville Journal Prentice criticized Washington and expressed doubts that blacks were capable of serving in the military. Moreover, he argued that black recruitment was an abolitionist scheme to "subjugate the South.",66 Hodges, editor of the Frankfort Commonwealth, characterized black enlistment as "insane." ${ }^{67}$ The opinions of these two staunch Union men were characteristic of sentiment around the state.

Indeed, many of Kentucky's prominent Unionists vehemently opposed what they considered an appalling policy. Colonel Frank L. Wolford of the $1^{\text {st }}$ Kentucky Cavalry was a well-respected Union officer until the spring of 1864 . Having enlisted early in the war, Wolford fought at the Battle of Mill Springs in January 1862 and then gained renown as he battled Confederate raider John Hunt Morgan across the state. ${ }^{68}$ On March 10, 1864, shortly after recruitment began across the state, Unionists in Fayette County rewarded Wolford's service, offering him gifts and inviting him to speak in Lexington. In his address, Wolford harshly criticized Lincoln's emancipation policy, stating that the President was guilty of "trampling upon the Constitution" and in "violation of the rules of

\footnotetext{
${ }^{65}$ This paragraph draws from information included in John David Smith, "The Recruitment of Negro Soldiers in Kentucky, 1863-1865," The Register of the Kentucky Historical Society 72 (October 1974): 364-90, especially 367-9.

${ }^{66}$ Louisville Journal, 4 February 1863, quoted in Smith, "Recruitment of Negro Soldiers," 367.

${ }^{67}$ Frankfort Commonwealth, 27 February 1863, quoted in Smith, "Recruitment of Negro Soldiers," 368.

${ }^{68}$ Hambleton Tapp, "Incidents in the Life of Frank Wolford, Colonel of the First Kentucky Union Cavalry," Filson Club Historical Quarterly 10 (April 1936): 85, 87-91.
} 
civilized warfare." ${ }^{, 99}$ To the military commanders of Kentucky, Wolford crossed the line when he encouraged "forcible resistance" to the recruitment of blacks. ${ }^{70}$ On June 27, army officials arrested Wolford and charged him with treason before dishonorably discharging him. Lieutenant Governor Richard T. Jacob also denounced black recruitment, often joining Wolford at public formums, and was briefly banished to the Confederacy. ${ }^{71}$ In Kentucky, Wolford and Jacob received loud applause for their stance against the administration. Historian Hambleton Tapp stated that after his dismissal, Wolford became "the most popular man in Kentucky." "2 In early April 1864, Ann Clay informed her husband, Brutus, of reports that Wolford had spoken before "a delighted audience" in Paris, Kentucky. ${ }^{73}$ Later that month, Brutus's son Sidney wrote to him that "the gallant Wolford is now the most popular man in our part of the state." $"$ Sidney continued that Lincoln, on the other hand, was "universally condemned for his tyranical course" in dishonorably discharging Wolford. Captain James M. Fidler reported that when Wolford and Jacob spoke near Lebanon in May 1864 they "so infuriated the people that the Board of Enrolment could not have remained in Lebanon but for the presence of Federal bayonets." ${ }^{75}$ The outcry of support for Wolford indicates the deep seated opposition to black soldiers.

\footnotetext{
${ }^{69}$ Lexington Observer \& Reporter, 12 March 1864, quoted in Tapp, "Incidents in the Life of Frank Wolford," 91.

${ }^{70}$ J. A. Jacobs to Abraham Lincoln, 13 March 1864, in OR, Series III, vol. 4, 174-5. In a letter to Lincoln, Wolford denied that he had encouraged resistance, but several reports of the incident state otherwise; Frank Wolford to Abraham Lincoln, 30 July 1864, Lincoln Papers-LC.

${ }^{71}$ Coulter, Civil War and Readjustment in Kentucky, 207.

${ }^{72}$ Tapp, "Incidents in the Life of Frank Wolford," 92.

${ }^{73}$ Ann Clay to Brutus J. Clay, 6 April 1864, Clay Family Papers-UK.

${ }^{74}$ Sidney Clay to Brutus J. Clay, 18 April 1864, Clay Family Papers-UK.

${ }^{75}$ Report of James M. Fidler, Provost Marshal of the $4^{\text {th }}$ District of Kentucky, 15 June 1865 , in Ira Berlin, et al., eds., Freedom: A Documentary History of Emancipation, 1861-1867, Series II, The Black Military Experience (Cambridge: Cambridge University Press, 1982), 258.
} 
United States Congressman Brutus J. Clay also opposed and, less conspicuously, resisted black recruitment. Although the owner of over 130 slaves in 1860, Clay supported the Union cause. ${ }^{76}$ The brother of Cassius M. Clay, an emancipationist and Lincoln's ambassador to Russia, Brutus had ties to some of the strongest Unionists in the country. His support of the Union, however, did not extend to the enlistment of African American soldiers. Throughout the first session of the $38^{\text {th }}$ Congress, beginning in December 1863, Clay denounced plans for black recruitment as a violation of property rights and a harbinger of "civil war among us [the population of Kentucky]." 77 Moreover, he believed Lincoln's policies would "crush out the Union sentiment" in Kentucky and leave a disloyal populace. In his personal life, Clay also resisted the enrollment of black troops. Clay stated that he would tell his slaves that the Union army only wanted them so they could be killed off by "hard work \& exposure \& in battle in place of those cowardly scoundrels from the North." ${ }^{78}$ Clay even claimed that he would urge his slaves to runaway rather than enlist. In an effort to deter the recruiters who began to visit his plantation near Paris, Kentucky, Clay told his wife to act ignorant when asked about their slaves. ${ }^{79}$ In August 1864, after the military took two of his slaves, allegedly under the age of eighteen, Clay wrote to Major General Stephen Gano Burbridge, Commander of the Department of Kentucky, requesting that they be returned to him. ${ }^{80}$ While Clay never took actions as drastic as those of Wolford and Jacob, his opposition to black soldiers speaks to white discontent with the enlistment process.

\footnotetext{
${ }^{76}$ United States of America, Bureau of the Census, Eighth Census of the United States, 1860.

${ }^{77}$ Congressional Globe, $38^{\text {th }}$ Congress, ${ }^{\text {st }}$ Session, 600.

${ }^{78}$ Brutus J. Clay to Ann Clay, 12 March 1864, Clay Family Papers-UK.

${ }^{79}$ Brutus J. Clay to Ann Clay, 25 March 1864, Clay Family Papers-UK.

${ }^{80}$ Brutus J. Clay to Stephen Gano Burbridge, 23 August 1864, Stephen Gano Burbridge Papers, Perkins Library, Duke University, Durham, NC.
} 
Wolford, Jacob, and Clay were only some of the more prominent examples of Kentucky's opposition to the recruitment of African American troops. White Kentuckians from all classes and regions criticized the use of black soldiers. Benjamin S. Jones, a Kentucky corporal from Barren County, vehemently opposed the use of black recruits. In February 1864, he wrote that he had seen a regiment of black troops in Tennessee and that he did not want to see any more. He continued, "I reckon that the negros will be freed before this war is ended and then old abe lincoln will be satisfied[.] I wish that he had to Sleep with a negro every night as long as he lives and kiss ones ass twice a day." ${ }^{\prime 81}$ Jones's brother, William, told his parents that he had heard blacks were being recruited in Kentucky and that if the government wanted him "to fight they had Better keep the negroes Back. ${ }^{.82}$

Going beyond verbal opposition, many were willing to violently attack blacks in order to curb enlistment. In June 1865, Captain James M. Fidler, the Provost Marshal of the $4^{\text {th }}$ District of Kentucky, filed his final report about black enlistment. ${ }^{83}$ Stationed in Lebanon, Fidler commented on violence toward African American recruits in the area during the summer of 1864 . He told of seventeen slaves from Green County, who after they attempted to enlist, were attacked by a "mob of young men of Lebanon" who "seized them and whipped them most unmercifully with cow-hides." Fidler reported numerous other assaults, whippings, and murders of black recruits and white recruiters. As a result of the violence, Fidler recounted that it became "absolutely necessary for the

\footnotetext{
${ }^{81}$ Benjamin S. Jones to "Dear Brother," 12 February 1864, Union Soldier Letters, The Filson Historical Society, Louisville, KY. Hereafter cited as Union Soldier Letters-FHS.

${ }^{82}$ William C. Jones to Moses P. and Sarah Jones, 1864, Union Soldier Letters-FHS.

${ }^{83}$ Report of James M. Fidler, 15 June 1865, in Berlin, et al, The Black Military Experience, 256-9.
} 
protection of the slave to enlist him without the consent of the owner." ${ }^{\text {"84 }}$ In June 1864, Lorenzo Thomas, the Adjutant General of the army, recognizing the difficulties recruiters faced, issued General Orders No. 20, which stated that "all who present themselves for enlistment will be received and enlisted into the service of the United States," even without the permission from their owners. ${ }^{85}$ This document, echoing an earlier edict issued by the Provost Marshal General of Kentucky, caused outrage among the state's white population, which continued to commit violent acts against black recruits.

The outrage over black troops continued after the war. Because units were mustered out in order of seniority, many of the USCT regiments were the last to be discharged. By September 1865, almost eleven thousand Union soldiers remained in Kentucky, all of them black. ${ }^{86}$ Robert A. Nelson from Mercer County complained about black troops in the state to his son, Frank, who served with the $21^{\text {st }}$ Kentucky Infantry. After the war, much to his father's chagrin, Frank Nelson's regiment was sent to Texas. Believing his son should have already been discharged, Robert wrote, "If it is the policy of the Rulers to hold a standing army in the field and upon the Frontier why don' they put our Black soldiers in that position - They are not needed here - They are a nuisance." ${ }^{\Perp 87}$ Sarcastically, Robert continued, "[A]nd if the extravagant eulogy bestowed so lavishly upon these Black warriors is to be credited they are the very men for the occasion for frontier service." When the War Department did discharge USCT regiments, white Kentuckians made it difficult for black veterans to assimilate into civilian life. General Clinton B. Fisk, head of the Freedmen's Bureau in Kentucky and Tennessee, reported

\footnotetext{
${ }^{84}$ Ibid., 257.

${ }^{85}$ Lorenzo Thomas, General Orders No. 20, 13 June 1864, in OR, Series III, vol. 4, 429.

${ }^{86}$ Report of Thomas M. Vincent, 14 September 1865, in OR, Series III, vol. 5, 114.

${ }^{87}$ Robert A. Nelson to Frank V. Nelson, 3 July 1865, Robert A. Nelson Papers, The Filson Historical Society, Louisville, KY. Misspelling in original.
} 
that the veterans were often "scourged, beaten, shot at, and driven from their homes and families." $" 88$

Kentucky's final stand against emancipation was its opposition to the Thirteenth Amendment. From April 1864, when the amendment received its first debate in the Senate, to January 1865 , when it passed both houses, most of Kentucky's congressional delegation worked to prevent its passage. Among the amendment's supporters were Representative George H. Yeaman, who realized that blocking the amendment would do little to preserve slavery in Kentucky, and Green Clay Smith, a former Union general and an Unconditional Unionist representative, who hoped in would establish peace in the state by removing the divisive issue of slavery. ${ }^{89}$ Most of Kentucky's representatives, however, opposed the amendment just as they had the Confiscation Acts, the Militia Act, and other emancipation legislation. Senator Garrett Davis was so angered by the amendment that he proposed a counter amendment that would re-form the six New England states into two larger states. ${ }^{90}$ Robert Mallory, a Unionist Representative, feared that adoption of the amendment would mark "a radical change of the Government of the United States." 91 Mallory believed that the change in the Constitution would improperly redistribute power so that the federal government would be superior to the states. Brutus Clay argued that the amendment unfairly punished Kentucky. He portrayed the state as a victim that had supported the Union throughout the war only to be penalized at the end. ${ }^{92}$ The arguments of these Kentuckians did little to curb pro-emancipation sentiment in

\footnotetext{
${ }^{88}$ Clinton B. Fisk to O. O. Howard, 14 February 1866, quoted in Berlin, et al., The Black Military Experience, 769.

${ }^{89}$ Congressional Globe, $38^{\text {th }}$ Congress, $2^{\text {nd }}$ session, $168-72,234-7$.

${ }^{90}$ Congressional Globe, $38^{\text {th }}$ Congress, $1^{\text {st }}$ session, 1364.

${ }^{91}$ Congressional Globe, $38^{\text {th }}$ Congress, $2^{\text {nd }}$ session, 178.

${ }^{92}$ Ibid., 181-3.
} 
Congress, and the amendment received approval from the necessary two-thirds majority in the House on January 31.

When Congress sent the Thirteenth Amendments to the states in January 1865, Governor Bramlette encouraged the Kentucky General Assembly to ratify it. Bramlette, like many Kentuckians, believed slavery to be "irrevocably doomed to speedy extermination." ${ }^{93}$ Still, Bramlette hoped that Kentucky would receive compensation from Congress for the slaves freed by the amendment and suggested ratification on the condition that the state's slaveholders receive $\$ 34$ million from the federal government. ${ }^{94}$ To make the motion more acceptable to conservatives in the state legislature, a moderate faction proposed that freed slaves be given the same rights as free-born blacks, who under the Kentucky constitution had no social or political rights and few civil rights. ${ }^{95}$ In February, despite the proposals intended to appease conservatives, the Kentucky House of Representatives voted 56-28 to reject the amendment and the state senate did the same by a vote of 21-13. ${ }^{96}$ The legislature refused to accept the amendment even after it became part of the United States Constitution in December 1865.

Before the passage of the Thirteenth Amendment, many white Kentuckians realized that slavery would end with the war. However, they remained as angry about it in 1865 as they had been on January 1, 1863. In protest, they turned against the Republican administration and in some cases even the Union. Though most Kentuckians who turned against the Lincoln administration did not become Confederate sympathizers, a number of Kentucky Unionists were so repulsed by federal policy toward African

\footnotetext{
${ }^{93}$ Thomas E. Bramlette to the Kentucky Legislature, 1 March 1865, Lincoln Papers-LC.

${ }^{94}$ Michael Vorenberg, Final Freedom: The Civil War, the Abolition of Slavery, and the Thirteenth Amendment (Cambridge: Cambridge University Press, 2001), 217.

${ }^{95}$ Ibid.

${ }^{96}$ Harrison, Lincoln of Kentucky, 243-4.
} 
Americans that by the end of the war they commiserated with the defeated Confederates. On April 14, 1865, Ellen Wallace remarked, "The Confederacy has gone down. What will become of the fragments? Will they be again united in one glorious bond that has been purified by fire and blood never more to be severed, forever one and the same in prosperity and honor? Or shall the bayonet of a tryant [sic] pin them together in the bonds of eternal revenge and hate." ${ }^{.97}$ Only a few Kentucky Unionists lamented the collapse of the Confederacy as Wallace did, but many of them showed their political transformation in the years following the war. Kentucky was among the first of the southern states to restore rights to Confederate veterans, and by the end of the 1860s, former rebels controlled the state's government. What had turned Kentucky against the Lincoln administration was anger over federal emancipation policy and the enlistment and use of black troops.

${ }^{97}$ Wallace Diary, 14 April 1865, Wallace-Starling Family Diaries-KHS. 


\section{CHAPTER II}

\section{THE CONSTITUTIONAL RESPONSE TO EMANCIPATION}

On January 8, 1863, Kentucky Governor James F. Robinson submitted his annual message to the state legislature. Given the reaction of white Kentuckians to emancipation it is not surprising that Robinson responded to the Emancipation Proclamation, issued only a week earlier. Robinson used a variety of arguments to denounce emancipation, the proclamation, and the public policy. In particular, Robinson thundered that the proclamation was "unwarranted by the Constitution of the United States." Like their governor, white Kentuckians often opposed federal policy toward slavery because they believed it violated of the United States Constitution. This chapter does not address whether President Abraham Lincoln's actions were constitutional or not. Scholars have devoted countless pages to that important debate. ${ }^{2}$ Instead, this chapter analyzes and assesses the most common legal and constitutional arguments used by Kentuckians to criticize emancipation and the enlistment of black soldiers. First, Kentucky believed that the federal Constitution gave neither the President nor the Congress the power to abolish slavery. In addition, Unionists in the state criticized the Lincoln administration for

\footnotetext{
${ }^{1}$ Journal of the House of Representatives of the Commonwealth of Kentucky (Frankfort: John B. Major, 1863), 1124. Emphasis in original.

${ }^{2}$ Among others, see J. G. Randall, Constitutional Problems Under Lincoln, revised edition (Urbana: University of Illinois Press, 1951; reprint, Gloucester, MA: Peter Smith, 1963), Harold M. Hyman, A More Perfect Union: The Impact of the Civil War and Reconstruction on the Constitution (New York: Alfred A. Knopf, 1973), Harold M. Hyman and William M. Wiecek, Equal Justice Under Law: Constitutional Development, 1833-1875 (New York: Harper \& Row, Publishers, 1982), Mark E. Neely, Jr., The Fate of Liberty: Abraham Lincoln and Civil Liberties (New York: Oxford University Press, 1991).
} 
implementing plans that contradicted state constitutions, laws, customs, and traditions.

Finally, Kentuckians rejected emancipation because of its disregard for the rights of private property. Employing these three arguments as their base, Kentuckians constructed a constitutional response to emancipation.

Throughout the nineteenth century, Americans, North and South, revered the federal Constitution and, in most political debates, adopted constitutional rhetoric to support their arguments. During the Civil War, both northern Democrats and Republicans cited the Constitution, although they used it for quite different ends. ${ }^{3}$ Likewise, even when rebelling against the Union, secessionist leaders tied themselves to the Constitution, changing only a few passages when creating the founding document of the Confederacy. Respect for the Constitution and debate over its precepts extended beyond political leaders. As historian Harold M. Hyman argued, "Wherever Americans gathered, discussion resulted of political issues cast in constitutional terms." ${ }^{4}$ Whether common Americans were versed in constitutional theory or not, they felt a connection to the document and often referenced it when voicing their political opinions. ${ }^{5}$ The Civil War created numerous debates over the powers of Congress and the President under the charter. Could the President suspend the writ of Habeas Corpus? Could the federal government create a new state from part of an existing one? In Kentucky, the most important question was did the federal government have the power to abolish slavery? Most Kentuckians answered no. Even the handful of white Kentuckians who favored

\footnotetext{
${ }^{3}$ Michael Kammen, A Machine that Would Go of Itself: The Constitution in American Culture (New York: Alfred A. Knopf, 1986), 29-30, 62.

${ }_{5}^{4}$ Hyman, A More Perfect Union, 5.

${ }^{5}$ Although Hyman stated that antebellum political debates created a "generation with unprecedented expertness in the theory of the Constitution," constitutional scholar Michael Kammen doubted that the average American, and in some cases even elected officials, had anything like "constitutional expertise." Hyman, A More Perfect Union, 5; Kammen, A Machine that Would Go of Itself, 83.
} 
emancipation usually believed that slavery was a local or state issue that could not be legislated or proclaimed out of existence by officials in Washington.

The importance Kentuckians placed on the Constitution reflected a widespread American sentiment. When they believed the Republican administration was overstepping its constitutional boundaries, Kentuckians disparaged the President and Congress in constitutional terms. Sometimes Lincoln's critics in Kentucky simply stated that the federal government was "acting against the Constitution." Other times they offered more detailed explanations of how the Republicans trampled the Constitution. Even poorly educated Kentucky soldiers used the Constitution as the basis for their political opinions. Explaining his rationale for not reenlisting in the Union army, Corporal Benjamin S. Jones of the $21^{\text {st }}$ Kentucky Infantry wrote, "I dont think that the leading men is going according the Constitution and for that reason I did not go in to the veterans servis."7 Regardless of how they voiced their opposition, whether it was a simple statement of unconstitutionality or a nuanced dissection of federal behavior, Civil War-era Kentuckians demonstrated that they placed great importance on maintaining the sanctity of the Constitution as they understood it.

Throughout the war, most Kentuckians held a conservative view of the Constitution, similar to that of northern Democrats. Central to their interpretation was that the Constitution applied in war just as it did in peace. ${ }^{8}$ They did not believe that presidential or congressional powers radically expanded or changed as a result of the

\footnotetext{
${ }^{6}$ John David Smith and William Cooper, Jr., eds., A Union Woman in Kentucky: The Diary of Frances Peter (Lexington: University Press of Kentucky, 2000), 96.

${ }^{7}$ Benjamin S. Jones to "Dear Brother,"12 February 1864, Union Soldier Letters, The Filson Historical Society, Louisville, KY.

${ }^{8}$ Joel H. Silbey, A Respectable Minority: The Democratic Party in the Civil War Era, 1860-1868 (New York: Norton, 1977), 78.
} 
rebellion. Though some Kentuckians conceded that presidential power increased somewhat during war time, most maintained that his authority did not expand to include control over property, particularly slavery. Garrett Davis, one of Kentucky's United States Senators, reflected this conservative interpretation of the Constitution. Writing shortly after the end of the war, Davis laid out his constitutional beliefs, stating, "I learned what I know of our political institutions, by reading the constitution in the lights held up by Washington, Marshall, Webster and Clay." Those early politicians, he argued, had taught him that "each state expressly reserved its sovereignty - that the people of the states made the constitution of the U.S." During the war, Davis believed, the federal government had snatched all the powers it could, victimizing both the states and the people. Davis specified that property rights, among others, had been trampled by the Lincoln administration in its prosecution of the war. ${ }^{9}$ Davis asked:

Why is it that $[\$] 150,000,000$ of slave property has been struck down in Ky? that the great mass of that property has been without even the form of a law, taken from their owners by lawless power; and if those owners dare attempt to hold possession of this property, guarantied by federal \& state constitutions \& laws, they are arrested by negro soldiers, $\&$ forced away to military prisons? ${ }^{10}$

While emancipation was not his only concern, like many white Kentuckians he believed that federal policy toward blacks violated both the federal Constitution and the constitutions of the states. From a conservative nineteenth-century perspective, these federal actions seriously violated the tenets of the national charter and the traditional division of powers and duties between the states and the central government.

\footnotetext{
${ }^{9}$ Davis also spent much of the letter discussing the inequity of the suspension of the writ of habeas corpus.

${ }^{10}$ Garrett Davis to John B. Bruner, 15 September 1865, John B. Bruner Papers, The Filson Historical Society, Louisville, KY. Hereafter cited as Bruner Papers-FHS.
} 
As constitutional historian Phillip S. Paludan argued, Northerners saw attacks on slavery as an important part of their effort to preserve the Union and the Constitution. ${ }^{11}$ Most white Kentuckians however perceived no connection between the war for the Union and the status of their domestic institutions. As a result, they bristled when Lincoln and the Republican leaders in Washington attacked slavery and coupled human bondage with the Confederate cause. Throughout the war, Kentucky Unionists tried numerous means and arguments to demonstrate their loyalty while maintaining their human chattel. Shortly before Lincoln's signing of the Emancipation Proclamation, Reverend William T. McElroy criticized the policy in his journal but also wrote, "I am still for the Union the Constitution \& the enforcement of the laws."12 Union soldier John T. Harrington expressed similar sentiment, writing, "I enlisted to fight for the Union and the Constitution but Lincoln puts a different construction on things and now has us Union men fighting for his Abolition Platform and thus making us a hord [sic] of Subjugators, house burners, negro thieves, and devastators of private property."13 In 1863, while describing her uncle's views of the war, Bevie Cain of Breckinridge County succinctly stated the view of many Kentucky Unionists, writing that he "would like nothing better than the Union as it was and the Constitution as it is." ${ }^{\prime \prime}$ For Kentuckians, preservation of the Union and the Constitution could not be achieved by expanding federal power and attacking slavery.

\footnotetext{
${ }^{11}$ Phillip S. Paludan, A Covenant with Death: The Constitution, Law, and Equality in the Civil War Era (Urbana: University of Illinois Press, 1975), 20.

${ }^{12}$ William T. McElroy Journal, December 1862, William Thomas McElroy Papers, The Filson Historical Society, Louisville, KY.

${ }^{13}$ John T. Harrington to "Dear Sister," 19 January1863, John T. Harrington Letters, Kentucky Historical Society, Frankfort, KY.

${ }^{14}$ Bevie Cain to "Esteemed Friend," 10 February 1863, Bevie Cain Letters, Manuscripts, Kentucky Building, Western Kentucky University, Bowling Green, KY.
} 
Lincoln argued that his powers as Commander in Chief of the military gave him the authority to issue the Emancipation Proclamation. ${ }^{15}$ Many Kentuckians, however, denied that the President's powers expanded during times of war. They particularly opposed any expansion of executive authority to deal with slavery and emancipation. Regarding a proposal for gradual emancipation, Congressman Charles A. Wickliffe stated, "I have not, as yet, seen any necessity why we should violate the Constitution in order that we should do what is required of us ... I deny that a state of war increases or enlarges the powers of Congress." ${ }^{\text {16 }}$ In a speech before Congress on the Emancipation Proclamation, Representative George H. Yeaman asked, "Where did the President derive the power to do this great thing?" The Constitution created the office of the president and gave the office its power, Yeaman argued, but "among those [powers] given are none to issue such proclamations." Moreover, the Congressman stated, "It is very significant," he noted, "that the friends of these measures have not yet claimed that there is any direct authority for them, but only that they are ... useful and necessary war measures.” Yeaman, like many of his constituents, believed that the president was "abandoning the Constitution" and replacing it with "despotism."17

Many Kentuckians believed that the Lincoln administration cared little for the Constitution. In December 1862, Representative John W. Menzies argued that true

\footnotetext{
${ }^{15}$ Randall, Constitutional Problems Under Lincoln, 377-8.

${ }^{16}$ Charles A. Wickliffe, Speech of Hon C. A. Wickliffe, of Kentucky, on the Following Resolution: Resolved, That the United States ought to co-operate with any State which may adopt gradual abolishment of slavery, giving to such State pecuniary aid, to be used by such State in its discretion, to compensate for the inconvenience, public and private, produced by such change of system, Delivered in the House of Representatives, March 11, 1862 (Washington, DC: L. Towers \& Co., 1862), 8.

${ }^{17}$ George H. Yeaman, Speech of Hon. Geo. H. Yeaman, of Kentucky, on the President's Emancipation Proclamation, Delivered in the House of Representatives, December 18, 1862 (Baltimore: Printed by J. Murphy, 1863), 4.
} 
"friends of the Constitution" were the opponents of the Emancipation Proclamation. ${ }^{18}$ Representative Yeaman offered resolutions in the House, condemning the proclamation as "unwarranted by the Constitution" and "dangerous to the rights of citizens and to the perpetuity of a free people."19 In February 1863, Ellen Wallace wrote, "The constitution made by our fathers and sealed with their blood is nothing with them compared to the Negro." ${ }^{20}$ The following year, Bourbon County resident L. G. Ray wrote to Congressman Brutus J. Clay, "I perceive you being to feel the tyranical [sic] encroachments of the abolitionists, who heed neither law nor Constitution, in the accomplishment of their wicked purposes., ${ }^{21}$

Kentuckians saw federal - indeed any - interference with slavery as a criminal offense. In January 1863, the Louisville Journal supported Governor James F. Robinson's plan to sign legislation protecting slave property from "the practices of negrothieves in the garb of soldiers." ${ }^{22}$ While debating the proposed Thirteenth Amendment in Congress, Brutus Clay argued that Union troops in Kentucky had used the guise of military necessity to take "our slave and other property." ${ }^{23}$ Using that same logic, Clay noted, troops could justifiably seize "clothing, boots, and shoes" from northern manufacturers or rob banks to pay the soldiers. Because they viewed meddling with

\footnotetext{
${ }^{18}$ Congressional Globe, $37^{\text {th }}$ Congress, $3^{\text {rd }}$ session, 78.

${ }^{19}$ Ibid., 76. The resolution was quickly tabled.

${ }^{20}$ Ellen McGaughey Wallace Diary, 17 February 1863, Wallace-Starling Family Diaries, Kentucky Historical Society, Frankfort, KY. Hereafter cited as Wallace-Starling Family Diaries-KHS.

${ }^{21}$ L.G. Ray to Brutus J. Clay, 23 February 1864, Clay Family Papers, Margaret I. King Library, University of Kentucky, Lexington, KY. Hereafter cited as Clay Family Papers-UK.

${ }^{22}$ Louisville Weekly Journal, 13 January 1863.

${ }^{23}$ Congressional Globe, $38^{\text {th }}$ Congress, $2^{\text {nd }}$ session, 181.
} 
slavery as a crime, Kentucky officials sometimes arrested Union officers who harbored fugitive slaves. ${ }^{24}$

Kentuckians also believed Lincoln had misled them regarding his fidelity to the Constitution. During his first inaugural address on March 4, 1861, Lincoln assured the South that he would uphold the Constitution and that he would not interfere with southern property. ${ }^{25}$ However, by the summer of 1862 , Kentuckians believed that Lincoln's embrace of emancipation to prosecute the war constituted an unconstitutional course. In Congress, George Yeaman discussed the 1860 platform of the Republican Party and Lincoln's response to John C. Frémont's 1861 proclamation, pointing out that through the first year of the war the Republicans had promised to respect the South's domestic institutions. ${ }^{26}$ Yet, Lincoln, Yeaman believed, had succumbed to "blind fanaticism" and ordered emancipation. This sentiment grew as the war progressed. Describing the sentiments of Christian County residents, Ellen Wallace wrote, "They feel that Lincoln is indeed a greater traitor than Jeff Davis because he pretends to support the constitution by the very means he takes to destroy it." 27

The enlistment of black troops furthered Kentuckians' doubts about the constitutional powers of the President and Congress. In the July 1862 Senate debate over the Militia Act, Garrett Davis condemned the use of black soldiers as unconstitutional. Davis argued that they could not be used to fight for a Constitution which "guarantied them as property to their owners. ${ }^{28}$ Governor Thomas E. Bramlette wrote to Lincoln

\footnotetext{
${ }^{24}$ Randall, Constitutional Problems Under Lincoln, 195; Lowell H. Harrison, Lincoln of Kentucky (Lexington: University Press of Kentucky, 2000), 233-5.

${ }^{25}$ Roy P. Basler, ed., The Collected Works of Abraham Lincoln, 8 vols. (New Brunswick, NJ: Rutgers University Press, 1953), 4:262-71.

${ }^{26}$ Congressional Globe, $37^{\text {th }}$ Congress, $3^{\text {rd }}$ session, 131.

${ }^{27}$ Wallace Diary, 25 December 1863, Wallace-Starling Family Diaries-KHS.

${ }^{28}$ Congressional Globe, $37^{\text {th }}$ Congress, $2^{\text {nd }}$ session, 3205.
} 
criticizing the action. Bramlette argued that the authority to enlist black soldiers came from "the sanction of the laws of Nations," not from the power to call the militia. ${ }^{29}$

Consequently, Bramlette believed that the policy was invalid in Kentucky, which was not in rebellion. Moreover, the governor stated, any recruiters operating in the state were breaking Kentucky law and could be punished by state authorities. Colonel Frank Wolford, who had been arrested and dishonorably discharged from the Union service for opposing black enlistment, also used constitutional reasoning to voice his criticism. Writing to Lincoln in July 1864, Wolford argued that the use of black soldiers was unconstitutional and condemned the idea that an action in violation of the Constitution could help preserve the Union. "The idea of an unconstitutional policy becoming necessary to preserve the government and save the constitution," he wrote, "is like the idea of killing a man to save his life and keep him from dying of disease." ${ }^{30}$

Kentucky also opposed congressional efforts to amend the Constitution. Like many conservative nineteenth-century Americans, Kentuckians believed that the Constitution was a static, sacred text and that acceptable amendments clarified rather than revised the original document. ${ }^{31}$ Among the most vocal opponents to altering the Constitution were Kentucky's U. S. Senators, particularly during the early months of 1864 when Congress debated ratification of the abolition amendment. On April 8, Garrett Davis proclaimed that "the power of amending the Constitution does not authorize the abolition of slavery." "I deny," Davis continued, "that the power of amendment is illimitable. ... I deny that the power of amendment carries the power of

\footnotetext{
${ }^{29}$ Thomas E Bramlette to Abraham Lincoln, 1 February 1864, Lincoln Papers-LC.

${ }^{30}$ Frank Wolford to Abraham Lincoln, 30 July 1864, Lincoln Papers-LC.

${ }^{31}$ Michael Vorenberg, Final Freedom: The Civil War, the Abolition of Slavery, and the Thirteenth Amendment (Cambridge: Cambridge University Press, 2001), 6, 10-11, 15.
} 
revolution." Davis believed that the power of amendment was only "a power to reform, a power to improve," but that ratification of the Thirteenth Amendment would "revolutionize" and "destroy" the government. ${ }^{32}$ The Republican majority in Congress, however, held a different interpretation of the power to amend. The amendment passed Congress who sent it to the states for ratification.

The debate over the Thirteenth Amendment focused on one issue that Americans had debated since the founding of the United States: states' rights. References to the power of the states to control their domestic institutions often appeared in discussions of emancipation. Although conservative constitutional theorist Joel Parker was a New Englander, his understanding of the Constitution was similar to that of many Kentuckians. $^{33}$ Describing Parker's reaction to emancipation, historian Phillip S. Paludan wrote, "He knew that war demanded some deviation from established precedent, but general emancipation projected not just a deviation from constitutional traditions, but a repudiation of them - a true revolution undermining the fundamental principle of the entire constitutional experience: local control of local institutions." ${ }^{34}$ When the government in Washington proposed emancipation, Kentuckians opposed because the plan believed it undermined the power of the states, threatening the Constitution and the survival of the Union.

States' rights ideology was prevalent across the United States in the antebellum era. Historian Harold M. Hyman argued that although the theory was most common in

\footnotetext{
${ }^{32}$ Congressional Globe, $38^{\text {th }}$ Congress, $1^{\text {st }}$ session, 1489.

${ }^{33}$ In fact, during the House debate on the Second Confiscation Act, both Henry Grider and Charles A. Wickliffe cited Joel Parker's argument that Republicans were acting outside the Constitution; Henry Grider, Speech of Henry Grider, of Kentucky, on the Bills to Confiscate the Property and Free from Servitude the Slaves of Rebels, Delivered in the House of Representatives, May 22, 1862 (Washington, DC: Congressional Globe Office, 1862), 1, 7-8.

${ }^{34}$ Paludan, A Covenant with Death, 144.
} 
the South, it was "diffused widely if more thinly through the rest of the nation, especially in Democratic party councils. ${ }^{, 35}$ Likewise, historian Edward S. Corwin stated that secession based on states' rights was so worrisome to northerners precisely because the theory was so widespread across the country. ${ }^{36}$ By the Civil War, Kentucky had a mixed tradition when it came to states' rights theory. Although the Kentucky Resolutions of 1798 and 1799 were part of the foundation of secessionist ideology, Henry Clay, the arch nationalist, had been the state's most famous politician throughout the antebellum period. During the war, Kentuckians showed that their attachment to states' rights had not disappeared. ${ }^{37}$

Numerous Kentuckians believed the state constitution represented an obstruction to federal emancipation policy. Speaking in Congress in December 1861, Representative Aaron Harding proclaimed, "It is manifest that the Constitution of the United States secures to each State the right to have or not have the institution of slavery - just as essentially so, as it does the right to regulate your own common-school system." 38 "We have no more right to make war upon the institution of slavery," Harding continued, "than upon any other local institution." While debating the Second Confiscation Act in the Senate, Garrett Davis declared, "The free States have no more right to force the emancipation of slaves upon the slave States than the latter have to enforce slavery upon

\footnotetext{
${ }^{35}$ Harold M. Hyman, A More Perfect Union: The Impact of the Civil War and Reconstruction on the Constitution (New York: Alfred A. Knopf, 1973), 9.

${ }^{36}$ Commentary by Edward S. Corwin, in Federalism as a Democratic Process: Essays by Roscoe Pound, Charles H. McIlwain, Roy F. Nichols (New Brunswick, NJ: Rutgers University Press, 1942), 86.

${ }^{37}$ States' rights theory in general survived the war. For example, northern constitutional theorist John Norton Pomeroy continued to promote states' rights in the postbellum era; see discussion in Paludan, $A$ Covenant with Death, 219-48.

${ }^{38}$ Aaron Harding, Speech of Hon. A. Harding, of Kentucky, In the House of Representatives, December 17, 1861 (Washington, DC: Scammell \& Co. Printers, no date), 7.
} 
the North."39 Not only did Harding, Davis, and others in Congress argue that it was not their place to legislate emancipation, but Kentuckians thought that any policy that freed blacks violated the Kentucky Constitution. In January 1864, J. R. Bailey wrote to Brutus Clay that, "We cannot as a State on account of our Constitution accept compensated Emancipation."40 The following month, when a report reached Christian County that President Lincoln was preparing to authorize general emancipation, Ellen Wallace predicted, "I do not believe he dare do such a thing ... For it would be trampling state law and the constitution underfoot and making himself our master."41 Kentuckians believed that it was outside the power of the federal government to end slavery, and that in their state it would require a rewriting of the state constitution.

Even many of Kentucky's pro-emancipation Unionists opposed the manner in which the North pushed for abolition. Early in the war, James Speed supported compensated emancipation but only if instituted by the states. ${ }^{42}$ As a Kentucky state senator Speed went so far as to propose a bill to confiscate rebel property, including slaves, but he was part of the legislative majority that condemned the Emancipation Proclamation and argued that black freedom was a state issue. In April 1864, Kentuckian Edward F. Dulin, who believed it in the state's best interest to "get clear of the negro institution," wrote to state legislator E. Hubbard Smith that emancipation in Kentucky should be "done by her own people, in her own way, gradually and in her own time."

\footnotetext{
${ }^{39}$ Congressional Globe, $37^{\text {th }}$ Congress, $2^{\text {nd }}$ session, 1778.

${ }^{40}$ J.R. Bailey to Brutus J. Clay, 31 January 1864, Clay Family Papers-UK.

${ }^{41}$ Wallace Diary, 23 February 1864, Wallace-Starling Family Diaries-KHS.

${ }^{42}$ Jennifer M. Cole, "Semper Eadem: An Interpretation of the Life and Career of James Speed" (M.A. thesis, University of Louisville, 2003), 32-3; James Speed to Abraham Lincoln, 22 December 1861, Lincoln Papers-LC. Showing how pro-slavery Kentucky was by 1861, Speed stated that because of his confiscation bill he was "regarded as ultra, almost an abolitionist" by his fellow Kentuckians. By the middle of 1864, Speed had altered his view and supported what became the Thirteenth Amendment.
} 
Emancipation, Dulin continued, should not be instituted "by outsider pressure from people of other states, or the power of the Federal Gov." ${ }^{43}$

Promoting a view similar to that of many Kentuckians, Senator Lazarus W. Powell often used states' rights theory to defend Border State slavery. In the debate over emancipation in Missouri, Senator Robert Wilson proposed an amendment that stated the bill would go into effect only if approved by the citizens of Missouri. Speaking in favor of the amendment, Powell argued that the Senate should allow Missourians to determine "whether or not they will have the institution of slavery abolished in that State." ${ }^{44}$ The Senate rejected the amendment by an overwhelming majority, and Powell continued to oppose the bill. Finally, Powell asked, "If you can invade the soil of the State of Missouri with this kind of unconstitutional legislation, what security has Massachusetts that her soil may not be invaded and her dearest constitutional rights stricken down? What security has Kentucky? What security has Indiana and Illinois? None, sir, none."45 Regarding the Thirteenth Amendment, Powell proclaimed, "I want the Union with all the institutions that our fathers ordained; and I desire to leave to each State the control of its own domestic policy. ${ }^{, 46}$ For Powell and his constituents, the federal assumption of power to shape or end state institutions violated the Constitution.

When Kentuckians opposed emancipation using states' rights arguments, their primary concern was retaining the right to private property in humans. Some Kentuckians also voiced concerns about the slippery slope, wandering what other state issues would be regulated by the federal government if it began to interfere with slavery.

\footnotetext{
${ }^{43}$ Edward F. Dulin to E. Hubbard Smith, 5 April 1864, E. Hubbard Smith Miscellaneous Papers, The Filson Historical Society, Louisville, KY.

${ }_{44}^{44}$ Congressional Globe, $37^{\text {th }}$ Congress, $3^{\text {rd }}$ session, 791.

${ }^{45}$ Ibid., 803.

${ }^{46}$ Congressional Globe, $38^{\text {th }}$ Congress, $1{ }^{\text {st }}$ session, 1484.
} 
During the debate on the Thirteenth Amendment, Representative Robert Mallory laid out a prime example of this argument. If slavery could be controlled by Washington, Mallory asked, could not Congress also pass amendments regulating marriage or "the relations between guardian and ward. ${ }^{47}$ Such arguments were, however, straw men, and the major concern of white Kentuckians was the preservation of slavery.

As unappealing as it is to modern sensibilities, white southerners viewed their slaves as property. While most did not deny that blacks were human, they still considered slaves property akin to livestock, real property, or any other possession. Holding this opinion, many white Kentuckians believed that emancipation violated the right to property guaranteed in the Fifth Amendment of the federal Bill of Rights. Garrett Davis thought "that the government of the U.S. can not acquire an additional power whatever, except by an amendment of the constitution [and] that private property can not to be taken from the owner except for public and upon making him just compensation." Davis argued that the President had no power to seize private property and that the Constitution guaranteed "every person his property until it is taken from him 'by due course of law.",49 Lazarus Powell asked, "What kind of morals is that that will take from the people of a State against their will their property ... for the purpose of gratifying the fanatical zeal of a party temporarily in power?" ${ }^{50}$ In the mind of most Kentuckians, any proposal to end slavery was an unconstitutional attack on property rights. ${ }^{51}$

${ }^{47}$ Congressional Globe, $38^{\text {th }}$ Congress, $2^{\text {nd }}$ session, 178.

${ }^{48}$ Garrett Davis to John B. Bruner, 16 September 1865, Bruner Papers-FHS.

${ }^{49}$ Congressional Globe, $37^{\text {th }}$ Congress, $3^{\text {rd }}$ session, 531.

${ }^{50}$ Ibid., 802.

${ }^{51}$ On property rights in nineteenth-century America, see James W. Ely, Jr., The Guardian of Every Other Right: A Constitutional History of Property Rights, $2^{\text {nd }}$ edition (New York: Oxford University Press, 1998). 
As soon as Republicans proposed emancipation, Kentuckians approached the issue in terms of property rights. Representative John J. Crittenden brought up the subject during the debate over the First Confiscation Act, arguing that the federal government had never held the power to violate property rights and that matters were no different in a time of war. ${ }^{52}$ Pointing out that the Constitution specifically stated that forfeiture of property beyond the life of the offender could not be used to punish treason, Crittenden argued that the bill as written violated the federal charter. ${ }^{53}$ Crittenden asked, "Now I ask my friends everywhere if it is not a plain breach of the Constitution that a man shall forfeit his slaves?"54 After showing the disparity between the wording of the bill and the provisions of the Constitution, he continued, "In this, however else we may differ, there is an apparent unconstitutionality in this bill." Crittenden's arguments, however, had little effect in the House, and the bill passed the lower chamber four days later.

As the war progressed, Kentuckians sensed additional threats to their property rights. Shortly before the end of 1861, Aaron Harding predicted that adopting emancipation policy would result in Kentucky's Union soldiers “making war upon the institution of slavery - a war for the destruction of their own property."55 Writing to Governor Bramlette after black soldiers seized one of his family’s slaves, S. P. Cope exclaimed, "My cheek burns with the blush of wounded pride when I remember the vehemence with which I used to meet the charge that the authorities of our Government would ever render the property of loyal slave owners insecure." "I staked my all in the

\footnotetext{
${ }^{52}$ Congressional Globe, $37^{\text {th }}$ Congress, $1^{\text {st }}$ session, 411.

${ }^{53}$ Lincoln also worried about the constitutionality of permanent forfeiture; see Siddali, From Property to Person, 89-90.

${ }^{54}$ Congressional Globe, $37^{\text {th }}$ Congress, $1^{\text {st }}$ session, 412.

${ }^{55}$ Speech of Hon. A. Harding . . . December 17, 1861, 8.
} 
cause of the Union of our Fathers," Cope continued, "and now I will give all if need be to preserve it, but . . I can claim that my right of property shall be sacred and inviolate., 56 In January 1864, Brutus Clay wrote to Governor Bramlette requesting him to resist the "recruiting of Negroes." ${ }^{57}$ Clay stated, "The North is disposed to encroach upon our Constitutional rights $\&$ intervene in every possible way she can $\&$ if we [do not object] there is no telling when the encroachment will stop." During the debate over the Thirteenth Amendment, Clay argued that passing the amendment would "legalize what under the laws of the land has hitherto only been robbery." ${ }^{, 58}$ Likewise, Lazarus Powell noted of the Thirteenth Amendment, "I do not believe it was ever designed by the founders of our Government that the Constitution of the United States should be so amended as to destroy property., 59

In order to argue for the protection of slavery, some Kentuckians compared slaves to other forms of property. In the Senate debate on the abolition of slavery in the District of Columbia, for example, Garrett Davis inquired of a northern Senator if Congress had the right "to take all the lands, and all the houses and lots in this District from their owners. ${ }^{, 60}$ Davis was satisfied when the Senator responded that such a seizure would be unconstitutional. On December 18, 1862, George H. Yeaman used the floor of the House of Representatives as a forum to criticize Lincoln's Emancipation Proclamation, particularly its violation of property rights. Yeaman asked, “. . . if he [the President] can take my slave, by what system of reason do you convince me he cannot take my horse or

\footnotetext{
${ }^{56}$ S. P. Cope to Thomas E. Bramlette, 8 February 1864, Thomas E. Bramlette Papers, Kentucky D Department for Libraries and Archives, Frankfort, KY. Hereafter cited as Bramlette Papers-KDLA.

${ }^{57}$ Brutus J. Clay to Thomas E. Bramlette, 15 January 1864, Bramlette Papers-KDLA.

${ }^{58}$ Congressional Globe, $38^{\text {th }}$ Congress, $2^{\text {nd }}$ session, 182.

${ }^{59}$ Congressional Globe, $38^{\text {th }}$ Congress, $1^{\text {st }}$ session, 1483.

${ }^{60}$ Congressional Globe, $37^{\text {th }}$ Congress, $2^{\text {nd }}$ session, 1378.
} 
my plow, or the land I cultivate with that horse and plow?" ${ }^{61}$ He then answered his own question, "I apprehend the only reason will be found in the fact that there is in this country no great political party who hate horses, plows, and land." During the debate over the Thirteenth Amendment, Lazarus Powell used similar logic. Powell stated that if the federal government could "strike down property in slaves" it could also forbid owning horses or land. ${ }^{62}$

Kentuckians sometimes also used the failure of just compensation to attack federal policy. The place of compensation in plans for emancipation troubled Kentucky's congressional delegation. In 1862, they rejected Lincoln's proposal for compensated emancipation, but their dismissal was a rebuttal of emancipation in general. As Kentuckians realized that slavery was dying, however, they advocated compensation as a condition of emancipation legislation. During the debate on the Thirteenth Amendment, Lazarus Powell suggested additional wording that would require the government to compensate masters for their loss of property. ${ }^{63}$ So unpopular was this proposal that it received affirmative votes from only two men: the senators from Kentucky. In the same debate, Garrett Davis warned Charles Sumner, "I think that that Senator and all Senators ought to be very guarded in the terms they adopt when they take $\$ 500,000,000$ of property from other people . . and propose to give them no compensation for it." ${ }^{\prime 64}$ Even after the war, Kentuckians hoped that the government would compensate them for the slaves they had freed.

${ }^{61}$ Speech of Hon. Geo. H. Yeaman ... December 18, 1862, 8.

${ }^{62}$ Congressional Globe, $38^{\text {th }}$ Congress, $1^{\text {st }}$ session, 1483.

${ }^{63}$ Ibid., 1425.

${ }^{64}$ Congressional Globe, $38^{\text {th }}$ Congress, $1{ }^{\text {st }}$ session, 1489. 
While many of the objections Kentuckians made were theoretical in nature, they were more worried about interference with their private property in practice. The actions of northern soldiers in the state were of particular concern. In 1862, when Congress debated a bill to prevent the military from returning fugitive slaves, Garrett Davis proposed a change in wording to make the bill more palatable to Kentuckians worried about the antislavery sentiments of northern troops. Davis proposed that the bill prevent the army from returning runaways, but also stop soldiers from "detaining, harboring, or concealing any such fugitive." ${ }^{65}$ The Senate defeated the proposal despite the fact that senators from Delaware, Kentucky and Missouri all voted to confirm it. ${ }^{66}$ In December 1862, Union infantryman Thomas M. Gunn wrote to his mother, "Many of the officers had been complaining and murmuring during the past few days on account of alleged interferences in Ky with private property (niggers) on the part of some northern Regts.",67 Once the United States Colored Troops (USCT) began operating in Kentucky, white concerns about the preservation of property only increased. Observing the enlistment of black soldiers, Ellen Wallace wrote, "State laws and private property are no stumbling blocks to Lincoln's career of fanatism [sic] and wickedness." ${ }^{68}$ In the months after the recruiting stations opened in Hopkinsville and other towns, Kentuckians across the state complained about the USCT impressing slaves, which in their minds was a violation of state law and the property guarantees of the federal Constitution. ${ }^{69}$

\footnotetext{
${ }^{65}$ Henry Wilson, History of the Antislavery Measures of the Thirty-Seventh and Thirty-Eighth UnitedStates Congresses, 1861-1864 (Boston: Walker, Wise, and Company, 1864), 30.

${ }^{66}$ Davis's rewording was also supported by both Senators from California and one Senator from Minnesota; Wilson, History of the Antislavery Measures, 30.

${ }^{67}$ Thomas M. Gunn to "Mother," 3 December 1862, Gunn Family Papers, The Filson Historical Society, Louisville, KY.

${ }^{68}$ Wallace Diary, 18 September 1864, Wallace-Starling Family Diaries-KHS.

${ }^{69}$ Ibid., 30 September 1864; Lucas, A History of Blacks in Kentucky, 157-8.
} 
The importance Kentuckians placed on the Constitution and constitutional norms affected their view of Republican Party and Lincoln administration efforts to abolish slavery. Kentuckians believed that in passing emancipation legislation and proclaiming the freedom of slaves, Congress and President Lincoln had assumed powers they did not possess under the Constitution. Moreover, Kentucky Unionists condemned the Republicans for implementing laws that disregarded the Kentucky state constitution and the power of states to control their local affairs in general. Chief among their concerns was the role of the state in defending their private property - that is slaves. Kentuckians used these three arguments to build a constitutional attack on emancipation. 


\section{CHAPTER III}

\section{THE RACIAL RESPONSE TO EMANCIPATION}

Although constitutional and legal factors propelled Kentucky's opposition to emancipation, white Kentuckians also criticized federal policy in racial terms. This chapter explores how Kentuckians employed racist rhetoric to oppose emancipation and the use of African American soldiers. In general, they employed three arguments against emancipation and the enrollment of black troops. First, they argued that black freedom would spark servile insurrection. Throughout the antebellum period, Kentuckians, like most white southerners, worried about the day when slaves might revolt against their masters. Emancipation and the arming of blacks, they believed, could provoke a possible uprising. Second, Kentuckians perceived emancipation, and particularly black enlistment, as steps toward racial equality. Most whites believed African Americans to be inferior, and thus, federal emancipation policy debased the white population by placing it on the same level as blacks. The third argument Kentuckians used proved the most interesting. Building upon the idea of a paternalistic slave system, many Kentucky slaveholders argued that emancipation mistreated once happy slaves by casting them into a world where no one would look after them and where they could not take care of themselves. 
Most white antebellum Kentuckians believed they were superior to blacks. Like other southerners, Kentuckians held this view for a variety of reasons. ${ }^{1}$ Slaveholders convinced themselves that blacks were barbarous creatures tamed by the confines of slavery and civilized by the influence of their masters. Following the arguments set forth by proslavery ideologue William Drayton, southerners believed that slavery tamed blacks, but if the restrictions imposed by bondage were removed, they would revert to their natural state. Like Drayton, many whites in the South used the example of Haiti, often called San Domingo in the nineteenth century, to prove this point. ${ }^{2}$ In 1791 , slaves in San Domingo rose up against their French masters and a bloody civil war ensued. Drayton saw the slave revolt as proof of certain inherent black qualities. Slavery repressed these traits, but it could not eradicate them. Because whites thought blacks to be vicious savages in their natural state, Kentuckians, even many who opposed slavery in theory, argued that the peculiar institution was necessary to protect the white population. They believed that such racial enmity existed that it was impossible for blacks and whites to live together in peace.

In an 1864 speech in the United States Senate, Garrett Davis of Kentucky analyzed the inferiority of blacks, presenting some of the most common arguments Kentuckians made regarding race. Davis argued that blacks had never been innovative in language, mathematics, or arts, and when they did make advancements in those areas it was "under the pupilage of the white man and by slow processes." Davis used the

\footnotetext{
${ }^{1}$ The description of southern racism is drawn from George M. Fredrickson, The Black Image in the White Mind: The Debate on Afro-American Character and Destiny, 1817-1914 (New York: Harper \& Row, Publishers, 1971; reprint, Middletown, CT: Wesleyan University Press, 1987), 49-70, and supplemented by David Brion Davis, Inhuman Bondage: The Rise and Fall of Slavery in the New World (New York: Oxford University Press, 2006), 256-7; Harold D. Tallant, Evil Necessity: Slavery and Political Culture in Antebellum Kentucky (Lexington: University Press of Kentucky, 2003), 72-9.

${ }^{2}$ See Alfred N. Hunt, Haiti's Influence on Antebellum America: Slumbering Volcano in the Caribbean (Baton Rouge: Louisiana State University Press, 1988), especially 84-146.
} 
example of San Domingo to demonstrate that a dominant white population in restraining the savagery of blacks. Davis argued that blacks in San Domingo, once they had completed their revolt against the French leaders, began a "degeneration" and "a return march . . . to the barbarism of their progenitors." 3 Such beliefs reinforced white support for slavery and caused white Kentuckians to fear that when blacks were removed from the control of their masters they would take up arms against white southerners.

Rumors of uprisings caused panic throughout the South throughout the nineteenth century, and by the Civil War, the South had feared the specter of armed blacks for decades. ${ }^{4}$ Kentuckians were much like other white southerners in this regard. On no fewer than four occasions from 1810 to 1848 , panic over insurrection seized white Kentuckians. ${ }^{5}$ In 1810, 1838, and 1848, whites arrested the leaders of the suspected rebellions, real or imagined. A second scare in 1838 fizzled when nothing happened. In 1856, fear spread throughout the South that on Christmas Day slaves across the region would rise up and murder their masters. As part of the plot, slaves at the ironworks on the Kentucky-Tennessee border near Hopkinsville would fight their way from southwestern Kentucky to Indiana. As the stories spread across the state, new plot rumors appeared, spurring greater suspicion. Wishing that she had "half a dozen revolvers" to protect herself, Ellen Wallace, a slaveholder from Hopkinsville, was caught

\footnotetext{
${ }^{3}$ Congressional Globe, $38^{\text {th }}$ Congress, $1^{\text {st }}$ session, Appendix, 132.

${ }^{4}$ For a description of slave insurrections in southern society, see Bertram Wyatt-Brown, Southern Honor: Ethics and Behavior in the Old South (New York: Oxford University Press, 1982), 405-8. For Kentucky in particular, see J. Winston Coleman, Jr., Slavery Times in Kentucky (Chapel Hill: University of North Carolina Press, 1940), 85-95.

${ }^{5}$ Marion B. Lucas, A History of Blacks in Kentucky, vol. 1, From Slavery to Segregation, 1760-1891 (Frankfort: Kentucky Historical Society, 1992), 59-60; Coleman, Slavery Times in Kentucky, 88-95.
} 
up in the panic. ${ }^{6}$ From November 20, when she first mentioned it, to the middle of December, Wallace was obsessed with the rumors of violence. In Hopkinsville, townspeople horded ammunition and armaments, and they arrested as many as fifty blacks thought to be involved in the plot. ${ }^{7}$ One hundred and fifty Christian County men also formed a patrol to guard against the impending insurrection. ${ }^{8}$ Although no uprising occurred, Wallace recorded no fewer than nine hangings of black suspects. ${ }^{9}$ In the years preceding the Civil War, incidents such as John Brown's 1859 raid on Harper's Ferry reawakened fears of slave revolt. ${ }^{10}$

Because of the paranoia that resulted from rumors of servile insurrection, Kentuckians reacted harshly to antislavery whites who supported, or even hinted at the possibility of, slave revolt. In Lexington in 1845, Kentucky emancipationist Cassius M. Clay began publishing his antislavery newspaper, the True American. For two months, Clay met with little more than verbal criticism. Then, on August 12, Clay ran an editorial that suggested slave revolt was the imminent result of human bondage. Within a week, a mob closed down his newspaper and shipped his printing equipment north of the Ohio River. ${ }^{11}$ The treatment Clay received was tame compared to Kentuckians' response to later such statements. In November 1859, while visiting Massachusetts, Kentucky abolitionist John G. Fee argued that abolitionists needed more men with the spirit of John Brown. Although that sentiment was offensive enough to most white Kentuckians,

\footnotetext{
${ }^{6}$ Ellen McGaughey Wallace Diary, 11 December 1856, Wallace-Starling Family Diaries, Kentucky Historical Society, Frankfort, KY. Hereafter cited as Wallace Diary, [date], Wallace-Starling Family Diaries-KHS.

${ }^{7}$ Ibid.; Lucas, A History of Blacks in Kentucky, 60.

${ }^{8}$ Coleman, Slavery Times in Kentucky, 107.

${ }^{9}$ Wallace Diary, 7 December, 11 December, 12 December 1856, Wallace-Starling Family Diaries-KHS.

${ }^{10}$ On Brown, see Stephen B. Oates, To Purge This Land with Blood: A Biography of John Brown, $2^{\text {nd }}$ edition (Amherst: University of Massachusetts Press, 1984).

${ }^{11}$ Jacob F. Lee, "'Between Two Fires': Cassius M. Clay, Slavery, and Antislavery in the Kentucky Borderlands," Ohio Valley History 6 (Fall 2006): 60-63.
} 
newspapers in the state distorted his statements and created widespread outrage. In December, when Fee returned to his antislavery community at Berea, sixty men representing a larger group of opponents gave the Bereans ten days to leave the state or be killed. Thirty Bereans left following those threats, and by the following summer, over one hundred of Fee's followers had been driven from the state. ${ }^{12}$

While many Kentuckians feared the specter of race war, Ellen Wallace was particularly affected by the threats of black-on-white violence. Ironically, although most slaveholders feared revolt, they trusted their own slaves. As historian Bertram WyattBrown noted, southerners left their "doors unlatched, windows open, gates ajar. Slaves roamed in an out of the 'Big House' day and night ...."13 As historian Patricia Hoskins Simpson has shown, however, Wallace was afraid of her slaves. Simpson argued that after 1856, Wallace never trusted her slaves again, and she worried constantly about slave revolt. ${ }^{14}$ In April 1861, as the war began, Wallace described the national situation as a storm, but added, "There is yet one deeper shade to be added to the scene, that is servile insurrection." "In late 1862, she believed revolt "will be the consequence [of emancipation] unless the strong arm of the nation prevents it."16 As the war progressed, black freedom and the recruitment of African American soldiers compounded her fears.

Wallace was not alone in her concerns. In September 1861, in the aftermath of Frémont's Missouri proclamation, Joshua F. Speed wrote to Lincoln expressing his fear of slave revolt. Speed informed the president, "All of us who live in slave states whether

\footnotetext{
12 Tallant, Evil Necessity, 165-8, 213-4.

${ }^{13}$ Wyatt-Brown, Southern Honor, 405.

${ }^{14}$ Patricia Hoskins Simpson, “'When Will the Measure of Woe be Complete?': Ellen McGaughey Wallace: Life as a Kentucky Slave Mistress,” (M.A. thesis, Eastern Kentucky University, 2001), 42.

${ }^{15}$ Wallace Diary, 29 April 1861, Wallace-Starling Family Diaries-KHS.

${ }^{16}$ Ibid., 13 December 1862.
} 
Union or loyal have great fear of insurrection.." ${ }^{17}$ In December 1862, Representative George H. Yeaman responded to Lincoln's Emancipation Proclamation by warning of slave violence. Emancipation would, Yeaman argued, "result in a war of races." ${ }^{18}$ In February 1863, when Massachusetts recruited black contraband to help fill their enlistment quota, Senator Garrett Davis declared, "The negroes are reclaimed savages, and you want to put them in a position where they will relapse into savageism again."19 Like many southerners, Davis turned to San Domingo as an example of the results of emancipation. Davis asked his Senate colleagues, "How long were the negroes of San Domingo under the humanizing influence of the French; and yet ... how soon did they degenerate into barbarism and into the most bloody and diabolical devils?" ${ }^{20}$ As the war progressed and the Union enlisted black soldiers, white fears of a race war increased.

Building upon antebellum fears of slaves revolts, numerous reports of depredations and atrocities committed by USCT units in the state reinforced white concerns that armed blacks would retaliate against their former masters. Some of the more dramatic incidents involve violence perpetrated by black soldiers upon white civilians. In July 1864, Ellen Wallace wrote that her brother-in-law Arthur had been accosted by a "Negro Regiment."21 According to Ellen, the black soldiers committed "all manner of outrages, shaking their fist in his face and threatening to shoot him through if he opened his mouth." After plundering his house, the USCT regiment then impressed Wallace's male slaves and threatened to burn his home. Less than three months after

\footnotetext{
${ }^{17}$ Joshua F. Speed to Abraham Lincoln, 1 September 1861, Abraham Lincoln Papers, Library of Congress, Washington, DC. Available online at http://memory.loc.gov. Hereafter cited as Lincoln Papers-LC.

${ }^{18}$ Speech of Hon. Geo. H. Yeaman, of Kentucky, on the President's Emancipation Proclamation. ([Washington, DC?], 1862), 14.

${ }^{19}$ Congressional Globe, $37^{\text {th }}$ Congress, $3^{\text {rd }}$ session, 799-800.

${ }^{20}$ Ibid., 800.

${ }^{21}$ Wallace Diary, 3 July 1864, Wallace-Starling Family Diaries-KHS.
} 
Arthur Wallace's reported run-in with the USCT, a company of African American soldiers moved into Hopkinsville. The town's white population was horrified.

Describing the USCT encampment as a "long dreaded event," Ellen Wallace worried that she would have to remove her children from school "owing to the town being filled with Negro soldiers." 22 She continued, "It will be unsafe for a decent woman to walk the street." In January 1864, Wallace stated that her "chief fear" was the USCT units stationed along the Kentucky-Tennessee border: "Should they become insubordinate or beheaded by desperate Abolitionist and over-run the country, our condition would be fearful. ${ }^{23}$ When USCT soldiers became a common sight in Hopkinsville, Wallace believed that "white women ... will find it necessary to carry daggers and revolvers in their girdles in place of pin cushions and scissors., ${ }^{24}$

Across the state, Kentuckians feared the possibility of servile insurrection. In Lexington, Frances Peter feared that "before the war is over it is not improbable that we may have to fight them [black soldiers] as well as the secesh." ${ }^{25}$ In 1865, an anonymous USCT officer from Kentucky admitted that he had been responsible for "permitting, allowing, \& giving permission to my men to fire indiscriminately through the Town [probably Henderson]. ${ }^{26}$ Even after the war, Kentuckians complained about the USCT. W. M. Spencer wrote to Governor Thomas E. Bramlette in September 1865 informing him of violence committed by black soldiers in Lebanon, Kentucky. According to Spencer, "thirty or forty negroe [sic] soldiers ... using the most vociferous \& profane

${ }^{22}$ Ibid., 22 September 1864.

${ }^{23}$ Ibid., 20 January 1864.

${ }^{24}$ Ibid., 28 January 1864.

${ }^{25}$ John David Smith and William Cooper, Jr., ed., A Union Woman in Civil War Kentucky: The Diary of Frances Peter (Lexington: University Press of Kentucky, 2000), 136-7.

${ }^{26}$ Court-Martial Testimony by the Commander of a Kentucky Black Regiment, 29? May 1865, in Ira Berlin, et al., eds., Freedom: A Documentary History of Emancipation, 1861-1867, Series II, The Black Military Experience (Cambridge: Cambridge University Press, 1982), 419. 
language" threatened a discharged Union soldier and chased him through the streets of

Lebanon. Spencer added that other white men had been beaten and threatened and white women insulted. ${ }^{27}$ While it may never be known how accurate these descriptions were, white Kentuckians believed them and perceived a world turned upside down, a world in which whites were now subservient to blacks.

Another concern was the protection of personal property, particularly slaves. Bondsmen who fled to the Union armies often took their owner's wagons and horses. ${ }^{28}$ Numerous reports depict black soldiers stealing any number of items from civilians. In February 1864, A. Bradshaw of Paducah wrote to Governor Bramlette, complaining of groups of "these semi-baboons driving a gov. waggon [sic] up to some house either in the city or country and in the most insolent manner proceed to pack up whatever they may choose to claim as theirs and return in triumph to the redervous [sic] of the nations defenders. ${ }^{29}$ More troubling to white Kentuckians, the USCT was proactive in freeing slaves. Numerous reports from across the state corroborate that black soldiers impressed slaves. In February 1864, J. H. Mackenzie, a Union officer stationed in Paducah, complained of "armed negroes" being "permitted to go with impunity into the Dwellings of True and Loyal Men, use insolent language to the family and take by force the only servant of the family." ${ }^{30}$ In June 1864, the $120^{\text {th }}$ United States Colored Infantry traveled through Henderson County "seizing negroes and carrying them off without their own consent. ${ }^{, 31}$ Ellen Wallace commented on impressments, including incidents in

\footnotetext{
${ }^{27}$ W. M. Spencer to Thomas E. Bramlette, 20 September 1865, Thomas E. Bramlette Papers, Kentucky Department for Libraries and Archives, Frankfort, KY. Hereafter cited as Bramlette Papers-KDLA.

${ }^{28}$ Wallace Diary, 28 May 1864, Wallace-Starling Family Diaries-KHS.

${ }^{29}$ A. Bradshaw to Thomas E. Bramlette, 9 February 1864, Bramlette Papers-FHS.

${ }^{30}$ J. H. Mackenzie to Thomas E. Bramlette, 10 February 1864, Bramlette Papers-KDLA.

${ }^{31}$ Abraham Lincoln to Lorenzo Thomas, 13 June 1864, in War of the Rebellion: A Compilation of the

Official Records of the Union and Confederate Armies (Washington, DC: Government Printing Office,
} 
September 1864, when "Negro armed soldiers going in gangs of forty" were "forcing" Hopkinsville slaves to join them. ${ }^{32}$ In March 1865, E. H. Green of Henderson wrote to Secretary of War Edwin E. Stanton, complaining that his slaves had been "forced into the Service at the point of the bayonet \& against their free will \& consent." ${ }^{33}$ Two of the men in question filed affidavits stating that they had been threatened with jail time if they did not enlist. ${ }^{34}$ Green argued that had the slaves been inducted legally, he would not have protested, as he had not when three others had enlisted.

As in the North, many Kentuckians doubted the ability of African Americans to become effective soldiers. When the Lincoln administration announced black enlistment, Louisville Journal editor George D. Prentice mocked the idea of "General Cuffee" and "Rear Admiral Sambo." ${ }^{35}$ In June 1864, even after black units fought well at Milliken's Bend in Louisiana and Battery Wagner in South Carolina, Louisvillian Arthur Peter wrote to his brother, Dr. Robert Peter of Lexington, arguing "the nigger [is] not worth the labor \& cost now being expended .... Nothing but desertion will follow their use as soldiers." ${ }^{36}$ Robert Peter's daughter, Frances, wrote in her diary that "the negro he is much too averse to work, too timid to make a good soldier," and "this arming \& equiping of negro regiments is a mere waste of time and money." ${ }^{37}$ Even a Kentuckian who commanded a black regiment complained of how difficult it was "to take charge of

1900), Series III, vol. 4, 429; Lucas, A History of Blacks in Kentucky, 157. John Glenn, the commander of the $120^{\text {th }}$ USCI, was court-martialed for allowing "the lawless and outrageous conduct" of his troops; Berlin, et al., The Black Military Experience, 420.

${ }^{32}$ Wallace Diary, 30 September 1864, Wallace-Starling Family Diaries-KHS.

${ }^{33}$ E. H. Green to Edwin M. Stanton, 14 March 1865, in Berlin, et al., The Black Military Experience, 272.

${ }^{34}$ Berlin, et al., The Black Military Experience, 273-4. In the same affidavits, both men explicitly stated that they wished to remain in the army.

${ }^{35}$ John David Smith, "The Recruitment of Negro Soldiers in Kentucky, 1863-1865," The Register of the Kentucky Historical Society 72 (October 1974): 368.

${ }^{36}$ Arthur Peter to Robert Peter, 19 June 1864, Catherine and Howard Evans Papers, Margaret I. King Library, University of Kentucky, Lexington, KY.

${ }^{37}$ Smith and Cooper, eds., A Union Woman in Kentucky, 96. 
illiterate, ignorant revengeful, blood-thirty negroes, \& bring them down in the space of 2 or 3 months to regular disciplined soldiers." ${ }^{, 38}$ The service of the USCT convinced many northerners that they had been mistaken to criticize the use of black soldiers. ${ }^{39}$ However, the performance of the USCT did not curb most Kentucky's opposition to black troops. Indeed, the state's residents often found evidence to support their prejudices in the reports of battles where blacks fought well. In response to Milliken's Bend, for example, John Henry Hammond, a Kentucky soldier in General William T. Sherman’s army, wrote, “I feel almost frightened at the consequences of this fight. . . . I fear a San Domingo."40

While Kentuckians feared violent reprisals from freedmen, they had other concerns as well. Emancipation and the enlistment of African American soldiers raised the question of racial equality. Whites feared that black freedom and army service constituted a smokescreen by abolitionists to either raise African Americans to the level of whites or degrade southern whites to the status of blacks. Most Kentuckians opposed a racially egalitarian society. In 1864, Garrett Davis, arguing against the repeal of the Fugitive Slave Laws of 1791 and 1850, stated, "Sir, I claim a proud superiority to the African race." "I am,” he continued, "a Caucasian by descent, I am a Celt by extraction, and ... I am of a superior race to them, and I intend to assert and maintain that superiority as long as I have the power." Yet, in his mind, northern abolitionists wanted to help blacks undermine white supremacy: "It is an immutable law of all inferior races . .

\footnotetext{
${ }^{38}$ Court-Martial Testimony by the Commander of a Kentucky Black Regiment, 29? May 1865, in Berlin, et al., The Black Military Experience, 419.

${ }^{39}$ Dudley Taylor Cornish, The Sable Arm: Negro Troops in the Union Army, 1861-1865 (New York: Longmans, Green, and Co., 1956); Joseph T. Glatthaar, Forged in Battle: The Civil War Alliance of Black Soldiers and White Officers (New York: Free Press, 1990; reprint, Baton Rouge: Louisiana State University Press, 2000); Fredrickson, The Black Image in the White Mind, 167-8; James M. McPherson, For Cause and Comrades: Why Men Fought in the Civil War (New York: Oxford University Press, 1997), 126-8. ${ }^{40}$ John Henry Hammond Diary, 8 May 1863, John Henry Hammond Papers, The Filson Historical Society, Louisville, KY.
} 
. to desire to pull down the superior race to their own inferiority; and the operation of this law in our country is one cause of the irrational clamor for negro equality."41 The superiority white Kentuckians felt contributed to their reaction against emancipation.

The use of black soldiers brought the issue of racial equality to the forefront. In August 1862, the Kentucky legislature passed a resolution that proclaimed, "The freeborn white men of this country ... will feel themselves disparaged and insulted by such an association, and to impose it upon them will drive more strength and courage from the Federal ranks than can be supplied by any possible levy of negroes."42 D. C. Wickliffe, editor of the Lexington Observer \& Reporter, believed that black enlistment brought "negro equality ... upon the country more speedily than was hoped for even by the most radical Abolitionist." ${ }^{43}$ In a September 1864 letter to President Lincoln, Governor Bramlette also discussed the importance of "preserving the rights and liberties of our own race," arguing that Kentuckians would not "sacrifice a single life, or imperil the smallest right of free white men for the sake of the negro." ${ }^{, 44}$

Kentucky politicians in Washington numbered among some of the most vocal opponents of racial equality. In the House of Representatives, Robert Mallory discussed the use of black soldiers, lamenting that they were stationed "behind fortifications and out of the reach of the guns of the enemy." Moreover, Mallory stated, "You have made them equal to white soldiers in pay, clothing, rations, and position; you make them superior to white soldiers by saving them from danger and wounds an death." Mallory concluded,

${ }^{41}$ Congressional Globe, $38^{\text {th }}$ Congress, $1^{\text {st }}$ session, Appendix, 132.

${ }^{42}$ Journal of the House of Representatives of the Commonwealth of Kentucky, 1861-1863 (Frankfort: John B. Major, 1863), 1075.

${ }^{43}$ Lexington Observer \& Reporter, 11 November 1863, quoted in Smith, "Recruitment of Negro Soldiers," 369.

${ }^{44}$ Thomas E. Bramlette to Abraham Lincoln, 3 September 1864, in Berlin, et al., The Destruction of Slavery, 606. 
"You make the white private soldier to a level with or below the negro.",45

Representative Aaron Harding likewise complained that racial equality resulted from black enlistment, yet he was also bothered by what he perceived to be northern hypocrisy on the issue. Referring to the congressional delegation from Massachusetts, Harding stated:

You want to force the white soldiers to an equality with the negroes, force them to associate and to mess with them, and force them to fight with them. How would you like it yourselves, as much as you love the negro? Are you willing to take them into your embraces and make them your associates in this House? Would you be willing to sit by them here and vote with them? Of course you would not. And yet you want to force the whites soldier in the Army into an equality with him. ${ }^{46}$

Kentuckians dreaded the thought of racial equality, but they believed that their opponents, the northern abolitionists pushing for emancipation and black enlistment, also opposed social equality.

While newspaper men and politicians filled the national debate with racial imagery, common Kentuckians echoed their sentiments. Civilians like Ellen Wallace believed that under slavery blacks had understood their proper place in society. With emancipation, however, she saw docile servants become independent persons, whose wishes did not coincide with those of their former masters. ${ }^{47}$ As early as February 1863 , Wallace believed that the Lincoln administration could "think of nothing but the Negro." "The interest of the white man," she argued, "is nothing in comparison to that of the Negro."48 For Wallace, the most egregious example of the Union supporting blacks over whites was the decision to arm them. By December 1863, according to Wallace, Lincoln

\footnotetext{
${ }^{45}$ Congressional Globe, $38^{\text {th }}$ Congress, $1^{\text {st }}$ session, 2982.

${ }^{46}$ Congressional Globe, $38^{\text {th }}$ Congress, $1^{\text {st }}$ session, 3433.

${ }^{47}$ Wallace Diary, 28 January, 20 February 1864, Wallace-Starling Family Diaries-KHS.

${ }^{48}$ Ibid., 17 February 1863.
} 
had made whites subservient to armed blacks. ${ }^{49}$ Wallace saw the enlistment of African Americans as an affront to white supremacy because the army forced white soldiers to march "side by side and shoulder to shoulder with Negro troops.",50 Enlisted men, such as Sergeant Hardy U. Jaggers, complained, "I dont like to be Eaquelized with a big Buck Nigger." ${ }^{, 51}$ Recording their thoughts in journals and letters to family members, these Kentuckians demonstrated that racial prejudice was more than a mere political tool; it was a reality for most whites.

Such individuals believed that emancipation and the use of black soldiers undermined white supremacy and what they perceived as the natural social order. Whites saw African Americans who seized their freedom as insolent and impudent. By the summer of 1864, Ellen Wallace had grown tired of dealing with African Americans who were in her mind "the only priviledged class" in Kentucky. Wallace believed that masters were required to tolerate "high handed impudence in whatever form they may chose [sic] to show it." ${ }^{, 52}$ During the war, blacks could choose whether to obey their owners or not. While the laws of Kentucky still bound them as chattel, the Union army offered freedom, and slaves could decide to leave a demanding or abusive master for federal lines.

Most white Kentuckians believed that it was impossible for African Americans to attain any level of prosperity without white supervision, and many opposed emancipation because they thought blacks were unable to care for themselves. Moreover, they did not believe northern abolitionists would provide the support necessary for blacks to survive.

\footnotetext{
${ }^{49}$ Ibid., 25 December 1863.

${ }^{50}$ Ibid., 7 June 1864.

${ }^{51}$ Hardy U. Jaggers to E. L. Jaggers, 23 August 1864, Hardy U. Jaggers Letters, Private Collection of Christy Bennett, Cecilia, KY.

${ }^{52}$ Wallace Diary, 1 May 1864, Wallace-Starling Family Diaries-KHS.
} 
Never abandoning antebellum defenses of slavery, Kentucky slaveholders argued that they were concerned for the wellbeing of blacks.

Historian Joel Williamson has described paternalism as a mechanism for white southerners to improve their own self-image. ${ }^{53}$ By imagining blacks to be subordinate, child-like heathens, whites legitimized their role as masters and also saw themselves as a kind and Christianizing influence. In June 1864, Representative Robert Mallory proclaimed, " $[T]$ he condition of slavery existing in my State and the other slave States is the best condition in which the African has ever been placed on the continent of America." ${ }^{54}$ Describing the views of her uncle, Bevie Cain of Breckinridge County emphasized the idea that "the poor Africans ... are best off with some one to look after them." ${ }^{55}$ This self-perception convinced southerners that their slaves were happier than northern free laborers. In January 1863, Louisville Journal editor George D. Prentice wrote, "The slaves as a body would not leave their masters if they could and could not if they would." ${ }^{56}$ Prentice believed that many blacks would remain enslaved because of their "attachment" to their owners. In January 1864, Ellen Wallace wrote that before the war "the negroes were cheerful and contented, adored their master and worked well." Even into the summer of 1864, she thought that her slaves were loyal to her and that they only left because abolitionist officers pressured them. ${ }^{58}$

\footnotetext{
${ }^{53}$ Joel Williamson, The Crucible of Race: Black-White Relations in the American South Since Emancipation (New York: Oxford University Press, 1984), 22-24. See also Eugene D. Genovese, The World the Slaveholders Made: Two Essays in Interpretation (New York: Pantheon Books, 1969), 30-31.

${ }^{54}$ Congressional Globe, $38^{\text {th }}$ Congress, $1^{\text {st }}$ session, 2983.

${ }^{55}$ Bevie Cain to "Esteemed Friend," 10 February 1863, Bevie Cain Papers, Manuscripts, Kentucky Building, Western Kentucky University, Bowling Green, KY.

${ }^{56}$ Louisville Weekly Journal, 6 January 1863.

${ }^{57}$ Wallace Diary, 14 February 1864, Wallace-Starling Family Diaries-KHS.

${ }^{58}$ Ibid., 3 July 1864.
} 
When Kentuckians argued that emancipation policy led to racial equality, they often pointed out that the northerners pushing for such measures were not any more willing to treat blacks as equals than southerners. Likewise, many Kentuckians proclaimed to care more for the well-being of African Americans than the northern abolitionists. In Congress in 1861, Aaron Harding stated, "[T]he abolitionist is the worst enemy of the slaves, and the humane master his truest and best friend." ${ }^{.59}$ In March 1864, Edward H. Taylor of Frankfort wrote to Lincoln discouraging the president from continuing his emancipation policy, noting, "I am a Slave holder individually care nothing except for their own sakes." Recalling that he had kept his son's slaves from being separated to pay debts, Taylor concluded, "Now who cared more for the Negro the abolitionist or myself." ${ }^{, 60}$ After the passage of the Thirteenth Amendment, John W. Jones of Bourbon County predicted that the abolitionists would betray the freedmen, who would soon "look back to the old fires of the master with tears \& mourn the disposition of by gone days. ${ }^{, 61}$ Kentucky slaveholders saw themselves as providers for a class of people who needed care that the abolitionists were unwilling to give. For that reason, they condemned northerners for wanting to end slavery while giving no thought to the condition of those freed.

Their paternalistic view of slavery led Kentuckians to warn northerners of the negative repercussions emancipation for freedmen. In December 1862, Representative George H. Yeaman predicted that colonization outside of the United States was impractical and that blacks would find life difficult in the country as well. Yeaman stated

\footnotetext{
${ }^{59}$ Speech of Hon. A. Harding, of Kentucky, in the House of Representative, December 17, 1861 ([Washington, DC]: Scammell \& Co.), 14.

${ }^{60}$ Edward H. Taylor to Abraham Lincoln, 16 March 1864, Lincoln Papers-LC.

${ }^{61}$ John W. Jones Diary, 22 December 1865, John W. Jones Diaries, Margaret I. King Library, University of Kentucky.
} 
that northerners would mistreat freedmen, if they were allowed in the North at all; yet, he saw little hope of southern whites living with their former property. Yeaman could not envision anything but hardship as a result of emancipation. ${ }^{62}$ In January 1863, Hamilton Gray of Maysville wrote to Lincoln complaining that emancipation will have a negative effect on southern blacks. Gray feared that freedmen would flock north and "become a pest to Society." Gray expressed concerns that the federal government would be unable and northerners would be unwilling to care for the refugees. He implied that white Kentuckians would take better care of blacks as slaves than as free persons. ${ }^{63}$ Robert Mallory was more explicit. In a speech before Congress, Mallory stated, "By destroying all interest of the master in the preservation of the health of the slave, you diminish his care and kindness and indulgence to him." ${ }^{, 64}$ For most white Kentuckians, slavery offered the best situation for both whites and blacks.

In voicing their concerns about post-emancipation conditions, Kentuckians at least implied, if they did not explicitly assert, that blacks were incapable of caring for themselves. For example, Mallory argued that after emancipation, "The watchful care of the intelligent and interested master over the young is lost, and they are left to grow up uncared for except by the negro father and mother, whose ignorance and indifference to the welfare of their offspring are matters of common notoriety." ${ }^{65}$ In June 1864, offering a typical analysis of black abilities, Garrett Davis feared that the emancipation of southern slaves would replicate the scene in San Domingo. He argued that blacks in San Domingo believed they were prepared to rule themselves, because they were under the

\footnotetext{
${ }^{62}$ Speech of Hon. Geo. H. Yeaman ... on the President's Emancipation Proclamation, 13-4.

${ }^{63}$ Hamilton Gray to Abraham Lincoln, 7 January 1863, Lincoln Papers-LC.

${ }^{64}$ Congressional Globe, $38^{\text {th }}$ Congress, $1^{\text {st }}$ session, 2983.

${ }^{65}$ Ibid.
} 
tutelage of whites. However, Davis contended, "They soon manifested their incompetence to the great duty, and . . . decaying prosperity and civilization proved how much better the condition of the island was when it was a slave possession of France." Many white Kentuckians believed that if the freedman's descent back into "barbarism" did not result in violence, it would prevent blacks from being anything but a drain on white society.

The paternalism of white Kentuckians became most clear in their descriptions of former slaves in Union camps. Ellen Wallace believed that before the war "confidence and trust" had existed between the master and slave. ${ }^{67}$ The relationship, however, was destroyed by the Union presence in Kentucky and Tennessee. Wallace argued that the Union army coerced slaves into joining them and leave behind their caring masters. In November 1863, she wrote, "The poor Negro is the innocent victim of this war. They are decoyed from their homes ... and then left to starve and die without shelter or any earthly comfort." ${ }^{68}$ In June 1864, Representative Henry Grider commented on the status of blacks who had been freed by the government, noting that before Kentucky accepted emancipation the state's "slaves must be ... cared for better than they are now, have food and raiment, and such advancement as they need and are competent to receive.",69 Wallace and Grider, like many white Kentuckians, believed slaveowners were the proper caregivers for blacks. When freedmen suffered in contraband camps, it convinced them that emancipation was the wrong course.

\footnotetext{
${ }^{66}$ Congressional Globe, $38^{\text {th }}$ Congress, $1^{\text {st }}$ session, Appendix, 132.

${ }^{67}$ Wallace Diary, 18 November 1863, Wallace-Starling Family Diaries-KHS.

${ }^{68}$ Ibid., 12 November 1863.

${ }^{69}$ Congressional Globe, $38^{\text {th }}$ Congress, $1^{\text {st }}$ session, Appendix, 123.
} 
Some Union military commanders did in fact refuse to provide for refugees. One of the more well known cases of federal negligence occurred at Camp Nelson, located in Madison County. By mid-1864, Camp Nelson was Kentucky’s largest black recruiting station. $^{70}$ The camp also attracted hundreds of women and children related to the soldiers who enlisted there. Legally, these blacks were not contraband or freedmen; they were runaways. Yet, many found themselves caught between the army, which could not accept them, and their masters, who often refused to care for them once their husbands and fathers joined the military. ${ }^{71}$ In July 1864, Adjutant General Lorenzo Thomas forbade camps to admit any additional dependants of USCT soldiers. ${ }^{72}$ At Camp Nelson, slaveholders who were aware of the order traveled to the camp to reclaim their property. The War Department, however, forced Thomas to rescind his order and directed him neither to encourage nor dissuade refugees from entering the camps. This change in policy, however, failed to prevent one of the most egregious examples of federal mistreatment of soldiers' families. In late November 1864, General Speed S. Fry, commander of Camp Nelson, expelled approximately four hundred women and children. Although the order was not the first of its kind, no previous expulsion had taken place in severe weather conditions. In rain and temperatures below freezing, many black dependants died from exposure as well as from starvation. Numerous stories tell of cold,

\footnotetext{
${ }^{70}$ Unless cited otherwise, the following account of Camp Nelson is compiled from Richard D. Sears, Camp Nelson, Kentucky: A Civil War History (Lexington: University Press of Kentucky, 2002), especially 1-li, 134-81; Berlin, et al., The Wartime Genesis of Free Labor, 671-73, 680-90; Ira Berlin, et al., "The Wartime Genesis of Free Labor, 1861-1865," in Slaves No More: Three Essays on Emancipation and the Civil War (Cambridge: Cambridge University Press, 1992), 160-61; Berlin, et al., The Black Military Experience, 194-96.

${ }^{71}$ For examples, see Affidavit of Joseph Miller, 26 November 1864, in Berlin, et al., The Black Military Experience, 269-71; Affidavit of John Higgins, in Berlin, et al., The Wartime Genesis of Free Labor, 68687.

${ }^{72}$ Lorenzo Thomas, Orders No. 24, 6 July 1864, in OR, Series 3, vol. 4, 474.
} 
hungry refugees along the road leading away from Camp Nelson. ${ }^{73}$ Conditions became so awful that one woman reportedly attempted to sell her baby for food. ${ }^{74}$ In June 1865 , Captain Theron E. Hall, a quartermaster officer at Camp Nelson, wrote of the expulsion, "Many died; and many contracted diseases from which, but few ever entirely recovered."75 Public outcry over the eviction forced officials to provide better care for the families of enlisted men, but it was too late to convince Kentuckians that the Union army would care for their former slaves.

Conditions in refugee camps were often dire even when those in charge had the best of intentions. The Union military did not have the infrastructure to care for the influx of thousands of freedpeople, and as a result, they endured hunger, unsanitary living conditions, and inadequate housing. ${ }^{76}$ Refugees suffered at Louisa, Louisville, Munfordville, Owensboro, and other Kentucky towns. At Paducah, Colonel W. H. Barry refused to return to slavery the women and children at Fort Anderson, but he also lacked the means to provide for them. ${ }^{77}$ In July 1865, three Union officers stationed in Bowling Green, Kentucky, reported that although some freedmen were doing well the "larger portion" were destitute, "having no means of subsistence ..., living in the building known as 'the old school house,' or in sheds, or deserted buildings . .., without beds or bedding, or any utensils for cooking." $" 78$ Even after public outrage led to improved treatment of the refugees at Camp Nelson, the humanitarians who took charge of the

\footnotetext{
${ }^{73}$ For examples, see documents in Sears, Camp Nelson, 134-160.

${ }^{74}$ Affidavit of John Vetter, 16 December 1864, in Berlin, et al, The Wartime Genesis of Free Labor, 68990 .

${ }^{75}$ T. E. Hall to O.O. Howard, 22 June 1865, in Berlin, et al., The Black Military Experience, 717.

${ }^{76}$ Lucas, A History of Blacks in Kentucky, 160.

${ }^{77}$ Victor B. Howard, Black Liberation in Kentucky: Emancipation and Freedom, 1862-1884 (Lexington: University Press of Kentucky, 1983), 114.

${ }^{78}$ L.B. Power, Paul R. Baldy, and E.C. Stevens to D.S. Bosworth, 3 July 1865, in Berlin, et al., The Wartime Genesis of Free Labor, 704-5.
} 
contraband camp could not alleviate all of its problems. In shelter similar to army barracks, women and children suffered from inadequate clothing, food, and medical care, and between April and July 1865, over one hundred women and four hundred children died at Camp Nelson. ${ }^{79}$ Through the last two years of the war, Kentucky blacks found themselves caught between slavery and freedom, between masters who would not and a military that could not care for them. Not recognizing their own role in the suffering, many Kentuckians used the circumstances of black refugees to condemn the actions of the Lincoln administration.

White Kentuckians feared that emancipation and black enlistment threatened southern society. Whites opposed the disintegration of slavery because it endangered white supremacy. Kentuckians became concerned that emancipation and especially the arming of freedmen encouraged African Americans to use violence against them. Building upon antebellum paranoia of slave revolts, whites believed that the removal of restrictions on blacks would result in uprisings. If the former slaves did not attack whites with guns and swords, Kentuckians believed that with the help of northern abolitionists blacks would undermine the status quo and achieve racial equality. Yet, Kentuckians also thought that blacks needed white supervision to avoid returning to savagery. Using paternalistic arguments that followed the same logic as antebellum defenses of slavery, many white Kentuckians considered blacks incapable of succeeding on their own. These three aspects made up Kentucky's racially based attack on emancipation and the use of African American troops.

\footnotetext{
${ }^{79}$ Lucas, A History of Blacks in Kentucky, 163; Sears, Camp Nelson, lii-liii.
} 


\section{CHAPTER IV}

\section{THE ECONOMIC RESPONSE TO EMANCIPATION}

While Kentuckians used constitutional and racial arguments to oppose emancipation, they began to discuss the economic ramifications of emancipation soon after black freedom became a reality. In the last years of the war, emancipation was a major blow to the southern economy. Southerners were renowned for being land and slave rich and money poor. With emancipation, Kentuckians lost millions of dollars in investment capital. Moreover, their farms and plantations also lost value as their ability to produce crops declined. Agricultural production dropped across the South, and Kentucky did not escape the general downturn. Tobacco production dropped by more than half in the state, the wheat crop decreased by almost two-thirds, and the hemp yield plummeted 80 percent. ${ }^{1}$ While the military presence in the state hampered agricultural production, the loss of a large portion of the workforce proved more significant. $^{2}$ Summing up Kentucky's situation, nineteen Kentucky slaveholders requested, on behalf of their counties, "the return of their Negroes . . . at least long enough to enable them to

\footnotetext{
${ }^{1}$ Marion B. Lucas, A History of Blacks in Kentucky, volume 1, From Slavery to Segregation, 1760-1891 (Frankfort: Kentucky Historical Society, 1992), 160.

${ }^{2}$ Lowell H. Harrison and James C. Klotter, A New History of Kentucky (Lexington: University Press of Kentucky, 1997), 207. Coulter overemphasizes the importance of military occupation on the economy and only briefly considers the effect of emancipation; Coulter, The Civil War and Readjustment in Kentucky, $245-48$.
} 
prepare their crops for market, which they cannot do without them." ${ }^{3}$ This chapter analyzes the ways in which the state's declining economy shaped Kentuckians' views of emancipation.

Slavery in Kentucky was different than the institution in most of the South. Slavery shaped the Border South's economy and culture. ${ }^{4}$ Unlike in the Deep South where agriculture depended on large quantities of laborers who grew cotton, sugar, and rice, the Border States' agricultural staples, increasingly grains, did not require extensive year-round labor like those produced in the Deep South. ${ }^{5}$ Although some areas of the state, particularly the Jackson Purchase and the counties surrounding Lexington, bore more resemblance to the staple economies of the Lower South, the average slaveholder in the state owned five slaves and almost one-fourth only owned one. ${ }^{6}$ By 1860 , despite the scarcity of traditional plantations in Kentucky, more slaveholders lived in Kentucky than in any state other than Virginia or Georgia. ${ }^{7}$ As a result, most white Kentuckian were connected in some way to the institution, although their ties usually came from owning one or two slaves rather than fifteen or twenty. Even more Kentuckians came to rely on

\footnotetext{
${ }^{3}$ Southern Kentucky Slaveholders to Abraham Lincoln, January 1864, in Ira Berlin, et al., eds., Freedom: A Documentary History of Emancipation, 1861-1867, Series II, The Black Military Experience (Cambridge: Cambridge University Press, 1982), 252.

${ }^{4}$ Historian Ira Berlin has noted that Delaware, Maryland, western Virginia, Kentucky, and Missouri were "societies with slaves" rather than "slave societies." Civil War era Kentucky does not conform to this distinction. The prevalence of slavery and its importance across society made it more significant in Kentucky than it was in Maryland or Delaware; Ira Berlin, Many Thousands Gone: The First Two Centuries of Slavery in North America (Cambridge, MA: Belknap Press of Harvard University Press, 1998), 8-9.

${ }^{5}$ Jacob F. Lee, “'Between Two Fires': Cassius M. Clay, Slavery and Antislavery in the Kentucky Borderlands," Ohio Valley History 6 (Fall 2006): 52.

${ }^{6}$ William W. Freehling, The South vs. the South: How Anti-Confederate Southerners Shaped the Course of the Civil War (New York: Oxford University Press, 2001), 23; Lucas, A History of Blacks in Kentucky, 2.

${ }^{7}$ E. Merton Coulter, The Civil War and Readjustment in Kentucky (Chapel Hill: University of North Carolina Press, 1926; reprint, Gloucester, MA: Peter Smith, 1966), 7
} 
slave labor as a result of the practice known as "hiring out." ${ }^{\prime 8}$ Slaves could be rented to accomplish specific tasks, to work during a particular agricultural season like planting or harvesting, or for an entire year. The flexibility of the system enabled Kentuckians who were either unable or unwilling to purchase slaves to benefit from their labor. Between slave ownership and slave hiring, a majority of Kentucky's population relied on bonded labor.

Emancipation's effect on the economy seems not to have entered the debate over black liberation until near the end of 1862. An increase in the number of runaway slaves served as the catalyst for Kentuckians to complain about the economic impact of black freedom. When Abraham Lincoln issued his Emancipation Proclamation, Kentucky's slaves gained confidence that they would not be turned away from Union camps. Although Kentucky blacks began fleeing their masters for Federal camps in 1861, Lincoln's proclamation standardized Union treatment of runaways. Slaves in the southwestern part of the Kentucky were especially susceptible to flight. Many slaves in the counties along the Kentucky-Tennessee border found refuge at recruiting stations a few miles across the state line. Ellen Wallace often complained about Christian County slaves who ran away, often in groups as large as sixty, to Fort Donelson, where they were protected by the "abolitionist," Colonel Abner C. Harding of the $83^{\text {rd }}$ Illinois Infantry. ${ }^{9}$ Harding, who took control of Fort Donelson in early 1863, refused to return runaways to their masters. By March, the refugee camp at Donelson housed approximately three

\footnotetext{
${ }^{8}$ On antebellum slave hiring in the Upper South, see Jonathan D. Martin, Divided Mastery: Slave Hiring in the American South (Cambridge, MA: Harvard University Press, 2004). For Kentucky in particular, see Lucas, A History of Blacks in Kentucky, 101-7.

${ }^{9}$ Ellen Wallace Diary, 28 May 1864, Wallace-Starling Family Diaries, Kentucky Historical Society, Frankfort, KY. Hereafter cited as Wallace Diary, [date], Wallace-Starling Family Diaries-KHS.
} 
hundred freedmen, and that number only increased. ${ }^{10}$ By November 1863 , the Union fort also operated as a recruiting center for African American soldiers. Also, slaves began to flee more frequently and in family groups, especially after March 1865 when Congress freed the families of soldiers. Because of its proximity to the state line, Fort Donelson was a convenient destination for slaves in southwestern Kentucky. By 1864, the presence of the Union military in Clarksville and at Fort Donelson encouraged almost nightly "stampedes" of runaway slaves. ${ }^{11}$

As the number of fugitives grew, Kentuckians began to complain to military and government officials. In December 1863, Benjamin H. Bristow wrote, with the endorsement of U. S. Representative George H. Yeaman and Unconditional Unionist politician C. F. Burnam, to Secretary of War Edwin M. Stanton presenting the case of those living in southern Kentucky. ${ }^{12}$ Bristow stated that the civilians in that area wished the recruiting stations along the border to be moved farther south and hoped that the camps could be made to refuse Kentucky blacks. The following month, Bristow wrote to Governor Thomas E. Bramlette that the citizens of Christian County had pleaded with him to help them maintain their slave property. According to Bristow, local civilians believed the Union army in Tennessee met runaway slaves at the border and "escorted [them] to the recruiting camp at Clarksville." 13 The flight of slaves from Christian

\footnotetext{
${ }^{10}$ Susan Hawkins, "The African American Experience at Forts Henry, Heiman, and Donelson, 1862-1867," Tennessee Historical Quarterly 61 (Winter 2002): 234.

${ }^{11}$ Wallace Diary, 20 January, 21 January, 22 January, 1864, Wallace-Starling Family Diaries-KHS; Harvey L. Eades Journal, 1 August 1863, Shaker South Union Collection, Manuscripts, Kentucky Building, Western Kentucky University, Bowling Green, KY. Hereafter cited as Shaker South Union CollectionWKU.

${ }^{12}$ Benjamin H. Bristow to Edward M. Stanton, 19 December 1863, in War of the Rebellion: A Compilation of the Official Records of the Union and Confederate Armies (Washington, DC: Government Printing Office, 1900), Series III, vol. 3, 1174-5. Hereafter cited as OR.

${ }^{13}$ Benjamin H. Bristow to Thomas E. Bramlette, January 1864, Thomas E. Bramlette Papers, Kentucky Department for Libraries and Archives, Frankfort, KY. Hereafter cites as Bramlette Papers-KDLA.
} 
County to Tennessee became so pervasive that slaveowners in the county petitioned both President Lincoln and Bramlette to help curb the runaways. Nineteen Hopkinsville-area slaveowners wrote Lincoln asking for "the relief of our suffering, but still Loyal people, by ordering the return of their Negroes." ${ }^{, 14}$ Specifically, the petition complained about the recruiting office in Clarksville, Tennessee, only about twenty-five miles from Hopkinsville and less than ten miles from the Christian County line. Slaves in and around Hopkinsville fled to Clarksville, and the petitioners reported that no owners had been able to retrieve their chattel regardless of loyalty.

Around the same time, twenty-four Christian County residents petitioned to Bramlette pleading that he help stop the runaways. ${ }^{15}$ The signers stressed that, "Some of our largest farmers \& best Citizens (loyal men) are losing all [their slaves] except the helpless ones." Feeling that the government should assist loyal Kentuckians in retaining their slave property, the petitioners asked Bramlette for help, writing, "We feel that loyalty \& protection should be inseperable [sic], and \& hope his [Bramlette's] authority will be used for our relief.” Benjamin H. Bristow corroborated their claims, writing, "Utter ruin is impending indeed I may say is already upon them."16 An August 1864 petition from seven "loyal Citizens of Todd County" to Adjutant General Lorenzo Thomas reported similar circumstances. ${ }^{17}$ The petitioners stated that in the twelve months prior "several hundred slaves" had fled to Clarksville.

\footnotetext{
${ }^{14}$ Southern Kentucky Slaveholders to Abraham Lincoln, January 1864, in Berlin, et al, eds., The Black Military Experience, 252.

${ }^{15}$ Petition from Loyal Citizens of Christian County to Thomas E. Bramlette, 23 January 1864, Bramlette Papers-KDLA.

${ }^{16}$ Benjamin Helm Bristow to Thomas E. Bramlette, January 1864, Bramlette Papers-KDLA.

${ }^{17}$ Loyal Citizens of Todd County to Lorenzo Thomas, August 1864, in Ira Berlin, et al., eds., Freedom: A Documentary History of Emancipation, 1861-1867, Series I, vol. 1, The Destruction of Slavery (Cambridge: Cambridge University Press, 1985), 601.
} 
White Kentuckians were concerned that the example of runaways would interfere with their ability to control their remaining slaves. In November 1862, when a "large Federal force" entered Hopkinsville, Ellen Wallace complained, "There was quite a large number of negroes following the army. I fear the effect on the slaves will be injurious."18 The following day Wallace described the $3^{\text {rd }}$ Kentucky Cavalry entering town. Among the Union cavalrymen was a group of "contraband negroes in a body with a banner." 19 Moreover, two of them were armed. Wallace wrote that the sight was "very offensive to all loyal citizens, however enthusiastick." She continued, "We cannot guess what the result of this thing will be, but we anticipate great trouble in the management of our servants to say the least." Within two days, Wallace's fears were confirmed: "The slaves in large number are constantly making their escape to different divisions of the Federal army." 20 The issue of black flight persisted and even expanded throughout the rest of the war.

While the presence of Union soldiers encouraged slaves to seek freedom within federal lines from the war's outset, slaveholders found black flight a greater problem when United States Colored Troops (USCT) units were stationed in the state. Indeed, Union officials used troops, black and white, to encourage Kentucky's black men to enlist in the army. Writing from Louisville, Adjutant General Lorenzo Thomas wrote to Secretary of War Stanton, "[R]ecruiting, to be fully successful, must be done with strong armed parties passing through the counties containing the most negroes." "The negroes," he continued, "seeing that protection will be offered them, will rapidly join the troops." 21

\footnotetext{
${ }^{18}$ Wallace Diary, 5 November 1862, Wallace-Starling Family Diaries -KHS.

${ }^{19}$ Ibid., 6 November 1862.

${ }^{20}$ Ibid., 8 November 1862.

${ }^{21}$ OR, Series III, vol. 4, 501.
} 
Thomas was correct. From the summer of 1864 until the end of the war, over 23,000 black Kentuckians enlisted in the military. ${ }^{22}$ Describing the extensive effect of black recruitment, James S. Brisbin wrote, "Negro enlistments have bankrupted slavery here, over 22,000 of the most valuable slaves having already gone into serve while the few thousands left are being rapidly gathered up by recruiting officers and put into the army." ${ }^{23}$ The enlistments extended beyond men suitable for military service, as Brisbin noted, "Even old men and boys are found to be fit for duty in Invalid Regiments and are taken. From ten to a hundred enlist daily, freeing ... an average of five women and children per man, thus from 300 to 500 black people are daily made free through the instrumentality of the army." As numerous historians have argued, black enlistment, for all practical purposes, ended slavery in Kentucky. ${ }^{24}$

Emancipation hurt Kentucky's economy in a variety of ways, beginning with the loss of capital investment. When developing his plan for compensated emancipation in Delaware, Lincoln proposed paying $\$ 400$ per slave. ${ }^{25}$ At that price, Kentuckians stood to lose over $\$ 90$ million if their slaves ran away or were freed without compensation, and Lincoln's offering was not even close to prevailing market values before the war. ${ }^{26}$ Although, by mid-1862, prices for slaves had plunged from a pre-war value of $\$ 500$ to $\$ 1200$ per slave to $\$ 200$ to $\$ 400$, Kentuckians could not justify accepting what they

\footnotetext{
${ }^{22}$ Marion B. Lucas, "Camp Nelson, Kentucky, During the Civil War: Cradle of Liberty or Refugee Death Camp?" Filson Club History Quarterly 63 (October 1989): 441.

${ }_{23}^{23}$ James S. Brisbin to Thomas E. Bramlette, 14 April 1865, Bramlette Papers-KDLA.

${ }^{24}$ Coulter, The Civil War and Readjustment in Kentucky, 247; Lucas, A History of Blacks in Kentucky, 15259 .

${ }^{25}$ Basler, ed., Collected Works, vol. 5, 160.

${ }^{26}$ This amount is calculated on Kentuckians owning 225,483 slaves; Kenneth H. Williams and James Russell Harris, eds., "Kentucky in 1860: A Statistical Overview," Register of the Kentucky Historical Society 103 (Autumn 2005): 751. On prices of slaves, see Table A.3.3 in Roger L. Ransom, Conflict and Compromise: The Political Economy of Slavery, Emancipation, and the American Civil War (Cambridge: Cambridge University Press, 1989), 75.
} 
believed to be an unfair price for their human property. ${ }^{27}$ The effect of emancipation on individual slaveholders cannot be underestimated. Over the course of the war, the value of slave property in Kentucky declined from $\$ 107,494,527$ in 1860 to $\$ 7,224,851$ five years later. ${ }^{28}$ As early as March 1862, the economic impact of emancipation worried Kentuckians like William C. Bullitt who predicted that emancipation would "take off four-fifths of my Estate. ${ }^{, 29}$ While few Kentuckians owned as large a number of slaves as Bullitt and his family, many had some investment in slave property. Kentucky's congressional delegation also recognized the impact emancipation would have on the slaveholders and argued against black liberation on economic terms. While debating the conscription of black soldiers, Representative Brutus J. Clay informed his colleagues that in 1860 Kentuckians had invested \$107 million, more than a fifth of the state's whole property value, in slaves. ${ }^{30}$

In addition to the loss of capital due to runaways, doubt regarding the longevity of the institution hurt the value of slave property in Kentucky. By mid-1863, the impending demise of slavery caused an insecurity that lowered the value of land and enslaved labor. In late 1863 , after months of watching numerous slaves flee from their owners in Hopkinsville, Ellen Wallace confessed, "I have no idea that we can hold our Negroes."”1 In October, she commented that "Negro property in Kentucky" was losing its value, and by December, she noted that a drop in land prices was the result of "the great uncertainty of slave labour." ${ }^{\prime 32}$ The following January, U. S. Representative Aaron Harding warned

\footnotetext{
${ }^{27}$ Coulter, The Civil War and Readjustment in Kentucky, 247.

${ }^{28}$ Lucas, A History of Blacks in Kentucky, 160.

${ }^{29}$ William C. Bullitt to Thomas W. Bullitt, 7 March 1862, Bullitt Family Papers-Oxmoor Collection, The Filson Historical Society, Louisville, KY.

${ }^{30}$ Congressional Globe, $38^{\text {th }}$ Congress, $1^{\text {st }}$ session, 599-600.

${ }^{31}$ Wallace Diary, 21 December, 23 December 1863, Wallace-Starling Family Diaries-KHS.

${ }^{32}$ Ibid., 20 October, 9 December 1863.
} 
his son of the "strong probability that all our negro property may be worthless or nearly so, in a few years. ${ }^{, 33}$ In Lexington, Frances Peter provided a good analysis of the situation. In February 1864, she reported that the "value of negroes is greatly depreciated. The hire of a servant for one year, being nearly, or quite equal to his fee simple value." Peter continued, "People do not care to risk the buying a species of property which if it does not 'take wings and fly away,' ... often makes good use of its legs and runs off." "So most people," she concluded, "prefer hiring to buying."”34

When slaves fled their owners, they often also took items required for agricultural production. As early as 1862 , Kentuckians worried about the loss of wagons and especially horses and mules. That December, Lieutenant Lewis Dunn of the Third Kentucky Cavalry advised his father, "The reason I object to have a negro hired is that he ... might run off or might steal a horse and then you would lose horse and the rest of the servants and a white man can leave when he pleases but without pay." ${ }^{35}$ August 1863 saw Shaker Harvey L. Eades write, "We learn that numbers of Negroes \& some horses are almost daily missing."36 In May 1864, Ellen Wallace reported, “About sixty Negroes left town last night taking rockaways and horses from their owners. ${ }^{, 37}$ In a time when armies on both sides impressed horses as they needed them, Kentucky's farmers could not afford the additional loss of their agricultural animals.

White Kentuckians also lost much of the manpower required to raise crops and perform other tasks. Although some farmers, like Bourbon County's C. F. Clay, worked

\footnotetext{
${ }^{33}$ Aaron Harding to John Harding, 17 January 1864, John Harding Papers, The Filson Historical Society, Louisville, KY.

${ }^{34}$ John David Smith and William Cooper, Jr., eds., A Union Woman in Civil War Kentucky: The Diary of Frances Peter (Lexington: University Press of Kentucky, 2000), 190.

${ }^{35}$ Lewis Dunn to Vincent Dunn, 5 December 1862, Dunn Family Papers, The Filson Historical Society, Louisville, KY.

${ }^{36}$ Harvey L. Eades Journal, 1 August 1863, Shaker South Union Collection-WKU.

${ }^{37}$ Wallace Diary, 28 May 1864, Wallace-Starling Family Diaries-KHS.
} 
their slaves especially hard knowing that they were to be freed, post-emancipation agriculture proved to be difficult for many Kentuckians. ${ }^{38}$ As early as June 1863, Kentucky farmers began to feel the effects of emancipation. Writing to Brigadier General Stephen A. Hurlbut, A. Bradshaw of Paducah complained of "the almost daily departure of slaves from their owners." Bradshaw continued that the flight of slaves had resulted in "the most ruinous consequences," particularly "the total loss of their crops, now in cultivation." Moreover, slaveholders suffered from "apprehension of the loss of the labor necessary to complete and secure their crops." 39 Ellen Wallace reported that several Christian County slaveholders were left with no laborers except those too "helpless" to flee or work. ${ }^{40}$

As the war progressed, slaves became fewer and it became more difficult for farmers to raise their crops. By March 1865, an estimated 71 percent of Kentucky's prewar slave population was legally free. ${ }^{41}$ In April 1865, General James S. Brisbin informed Governor Bramlette, "The Master can no longer hold his slaves or depend on their labor for a single day, so that producers cannot calculate their crops or pursue agriculture with any degree of certainty." ${ }^{42}$ In July, John M. Lee complained that General John M. Palmer's pass system was “producing a bad state of things here.” Lee went on to write, "[F]armers cannot obtain help to save their Crop.",43

\footnotetext{
${ }^{38}$ C. F. Clay to Brutus J. Clay, 19 March 1864, Clay Family Papers-UK.

39 A. Bradshaw to Stephen A. Hurlbut, June 1863, in Berlin, et al, The Destruction of Slavery, 584. Berlin and his co-editors misspell Hurlbut's name "Hurlbutt."

${ }^{40}$ Wallace Diary, 21 December 1863 ,

${ }^{41}$ Lucas, A History of Blacks in Kentucky, 160.

42 James S. Brisbin to Thomas E. Bramlette, 14 April 1865, Bramlette Papers-KDLA.

${ }^{43}$ John M. Lee to George H. Thomas, 26 July 1865, in Ira Berlin, et al, eds., Freedom: A Documentary History of Emancipation, 1861-1867, Series I, vol. 2, The Wartime Genesis of Free Labor: The Upper South (Cambridge: Cambridge University Press, 1993), 708.
} 
Because black enlistment increased the number of runaways, it intensified the labor shortage in Kentucky. Describing the situation of many of his fellow Kentucky farmers, W. Hamilton Stockwell of Boyle County wrote, "In view of this enrolment and also of the uncertainty in regard to the construction of the Bill we hardly know whether to make a commencement of farming or not." Stockwell continued, "Its efforts will I fear be almost ruinous on the central and southern parts of the states. What between enrolment \& draft volunteering \& stealing, and impressments ... I am afraid we shall soon have no negroes to work on our farms and no possibility of substituting any other labor." Stockwell wondered if Kentucky's congressional delegation could not "induce the Prest. by any sort of influence to postpone these measures until fall. How are we to live \& pay the heavy taxes imposed on us if no hands are left to us to till the ground." 44 In the end, Kentuckians found that they would have to do the best they could without a captive labor force.

The economic effects of emancipation were also felt outside the realm of agriculture. Daniel Hillman, owner of the Empire City Iron Works in Trigg County, was unable to continue operations after his slaves fled to army bases in Tennessee. Hillman reported that as many as thirty of his slaves had run away to Clarksville, Fort Donelson, and Fort Heiman, all just across the state line. As a result, Hillman had "stopped making iron for over 18 months owing to the uncertain tenure of my hands." Instead, he began to grow wheat and tobacco only to "doubt whether I shall be able to Save my Crop" due to the continued flight of his slaves. ${ }^{45}$ In Louisville, Ellen Bodley found it difficult to find a

\footnotetext{
${ }^{44}$ W. Hamilton Stockwell to Brutus J. Clay, 8 March 1864, Clay Family Papers, Margaret I. King Library, University of Kentucky, Lexington, KY.

${ }^{45}$ Daniel Hillman to Jeremiah T. Boyle, 29 June 1863, in Ira Berlin, et al., eds., The Wartime Genesis of Free Labor, 650-1.
} 
domestic servant. Writing to her husband, she complained, "I am told that it is almost impossible to get a good servant the demand is so great, in consequence of the coloured servants running off in such numbers. ${ }^{, 46}$ Because slavery touched so many sectors of the southern economy, few Kentucky industries were unaffected by emancipation.

Kentuckians also worried about the economic repercussions of the United States army hiring slaves. Although antebellum slave hiring had been a successful part of the slave system in Kentucky and the rest of the Upper South, the military proved less reliable than local businessmen. While slave hiring before the war had in some ways undermined the controls of slavery, wartime hiring placed the institution in a precarious state. As the Union adopted emancipation as a war goal, soldiers in Kentucky began to treat hired slaves as freedmen. An early problem was that the military sometimes paid wages directly to the slaves. In his August 1863 order impressing six thousand black laborers, Brigadier General Jeremiah T. Boyle specified that all wages should go to the slaves' owners, but this often did not happen. ${ }^{47}$ The previous month, Brigadier General Speed S. Fry at Camp Nelson reported that the clerk in charge of payroll had been paying slaves money that should have gone to their owners. ${ }^{48}$ In April 1864, Capt. W. W. Woodward, Provost Marshal General of the First Division of the District of Kentucky, reported that despite Boyle's order, "Many of the Counties have never received pay for this labor or [been] remunerated in any way.",49

\footnotetext{
${ }^{46}$ Ellen Bodley to "My dear husband," 20 July 1864, Bodley Family Papers, The Filson Historical Society, Louisville, KY.

${ }^{47}$ General Orders, No. 41, Department of Kentucky, in Berlin, et al., eds., The Destruction of Slavery, 586. ${ }^{48}$ Speed S. Fry to J. M. Wright, 13 July 1863, in Richard D. Sears, Camp Nelson, Kentucky: A Civil War History (Lexington: University Press of Kentucky, 2002), 6.

${ }^{49}$ W. W. Woodward to R. Morrow, 14 April 1864, in Berlin, et al., eds., The Destruction of Slavery, 599.
} 
The difficulty with recovering wages paid to slaves only increased after the war. In July 1865 , the owners of the Louisville Hotel hired Wilson, a slave owned by an $\mathrm{H}$. Hale of Simpson County. ${ }^{50}$ The hotel proprietors were unaware that Hale still owned their new employee and for the first month he worked at the hotel, they paid Wilson the wages he earned. By August, however, Hale had learned that his slave was working in Louisville and demanded the money earned be given to him. The hotel owners agreed, but Wilson complained to the Freedmen's Bureau, who in turn insisted that Wilson be paid. The bureau argued that slavery in Kentucky was "merely a nominal institution" and that Wilson, like all slaves in the state, was no longer property but a refugee, falling under the jurisdiction of the Freedmen's Bureau. In the end, Wilson collected his wages, and Hale received nothing. ${ }^{51}$

Once the military employed slaves, it became difficult for their owners to retain control of them. In February 1864, four slaveholders from Marion County complained to Governor Bramlette that in December 1863 they had hired out several slaves to work as teamsters for the military. ${ }^{52}$ At the end of January, however, the army relocated their slaves to Nashville. Once there, the slaves began to receive their own wages, and the quartermaster in Nashville ignored the slaveholders' claim to the pay. The petitioners were concerned that the army would not return their slaves when the hiring period was over. Bramlette forwarded their concerns to the War Department, which seems to have taken no action regarding their case. ${ }^{53}$

\footnotetext{
${ }^{50}$ H. A. McCaleb to Kean, Steele, \& Co., 11 September 1865; Kean, Steele, \& Co. to H. A. McCaleb, 11 September 1865, in Berlin, et al., eds., The Wartime Genesis of Free Labor, 715-6.

${ }^{51}$ Berlin, et al, The Wartime Genesis of Free Labor, 716.

${ }^{52}$ Hervey McElrey, John Lancaster, Sam Spalding, and R. M. Spalding to Thomas E. Bramlette, 24 February 1864, in Ira Berlin, et al, eds., The Destruction of Slavery, 595-6.

${ }^{53}$ A notation on Bramlette's letter to Edwin M. Stanton reads "No action at present"; Thomas E. Bramlette to Edward M. Stanton, 12 April 1864, in Berlin, et al., eds., The Destruction of Slavery, 598.
} 
Black Kentuckians soon realized that they should be the proper recipients of their wages. Writing in January 1865, T. A. Frazer of Russellville complained, "The negroes are generally of the opinion that the hire for this year will be ordered by the military authorities to be paid to them." ${ }^{, 54}$ Once owners realized that they would be unable to retain their slaves without compensation, some attempted to hire them as free laborers. One slaveholder in Lexington offered his slaves fifteen dollars a month and was able to maintain his entire workforce. ${ }^{55}$ Others proposed to share the products of the labor. ${ }^{56}$ While some of these efforts were successful, the exodus of slaves from the countryside to towns and cities created such a labor shortage that most farmers could not find enough workers even when pay was offered.

The absence of slaves was not the only difficulty for white Kentuckians. The promise of emancipation altered the behavior of many blacks still held by their owners. Some enslaved people became disaffected simply by the idea of impending liberation. Others witnessed freedom first hand. Numerous slaves worked alongside freedmen as laborers for the Union army in Kentucky. Their employment separated them from their masters, and they enjoyed increased liberty while working for the military. ${ }^{57}$ When these slaves returned to their owners, they often exhibited newfound independence. Many whites complained about the behavior of freedmen, finding them to be insolent and insubordinate, though such terms included any sign of independence or disobedience. ${ }^{58}$ Kentuckians often described the laziness of slaves who expected their freedom, in the

\footnotetext{
${ }^{54}$ T. A. Frazer to John B. Bibb, 12 January 1865, Bibb Family Papers, The Filson Historical Society, Louisville, KY.

${ }^{55}$ Howard, Black Liberation in Kentucky, 91

${ }^{56}$ Berlin, et al., eds., The Wartime Genesis of Free Labor, 636; Lucas, A History of Blacks in Kentucky, 159-60.

${ }^{57}$ Berlin, et al., eds., The Destruction of Slavery, 509.

${ }^{58}$ Eric Foner, Reconstruction: America's Unfinished Revolution, 1863-1877 (New York: Harper \& Row, 1988), 79.
} 
words of Congressman George H. Yeaman, "without either work or fight."59 In January 1864, Frances Peter reported, "They [the slaves] are restless, impertinent, discontented, neglect their work, and run off in great numbers. ${ }^{, 60}$ In April 1865, I. N. Steele, a slaveholder from Lexington, wrote to James S. Brisbin complaining that one of his slaves "has refused to serve me any longer, and affirms that he is as free as I am." Steele continued, "Said Boy has done me only one days work since Christmas." legally bound to their masters, slaves had an option which was not available to them before the war. If they grew tired of their masters, they could find work and shelter with the Union army.

Kentuckians realized the effect of emancipation on their economy. The flight of slaves from their owners to federal forces created a loss of both assets and labor. Hiring out slaves to the military further damaged Kentucky slaveholders' control of their slaves. Losing the millions of dollars they had invested in slaves and their captive workforce, Kentucky's economy suffered from a loss of capital and a decline in production. From the Emancipation Proclamation through the Thirteenth Amendment, slaveholders attempted to retain slavery. Despite their efforts, Kentucky's antebellum economic system disappeared during the war and they deeply resented their losses. Needing a scapegoat, they turned against the Lincoln administration and the Union cause.

\footnotetext{
${ }^{59}$ George H. Yeaman endorsement to Edwin M. Stanton on John S. McFarland to George H. Yeaman, 6 December 1864, in Berlin, et al., eds., The Destruction of Slavery, 609.

${ }^{60}$ Smith and Cooper, eds., A Union Woman in Kentucky, 187.

${ }^{61}$ Steele then requested that his "Boy," who was forty-nine years old, be enlisted in the army; I. N. Steele to James S. Brisbin, 1 April 1865, in Berlin, et al., eds., The Destruction of Slavery, 616.
} 


\section{CONCLUSION}

In July 1865, Brigadier General Clinton B. Fisk, Freedmen’s Bureau Assistant Commissioner in Kentucky and Tennessee, wrote to the head of the bureau discussing Kentucky's inability to let go of slavery. ${ }^{1}$ Fisk stated, “The devotees of the barbarism cling to its putrid carcass with astonishing tenacity - Kentucky I fear will refuse to become one of the twenty seven (27) pall bearers required to put the great abomination to its final resting place.” ${ }^{2}$ Fisk was correct. Kentucky, along with Delaware, refused to pass the Thirteenth Amendment. While the rest of the Union states embraced emancipation, many Kentuckians refused to accept the demise of slavery. From General John C. Frémont's 1861 proclamation emancipating the slaves of Missouri rebels to the ratification of the Thirteenth Amendment in December 1865, white Kentuckians continued to oppose emancipation. The arguments they used to resist black liberation came in three forms: legal and constitutional, racial, and economic. Stemming from the constitutionalism of the early-nineteenth century, many Kentuckians believed that presidential and congressional efforts at emancipation were unconstitutional. Moreover, Kentucky Unionists believed that federal emancipation policy violated state constitutions and laws and infringed upon the right to property. Kentuckians also based their opposition to emancipation on white nineteenth century perceptions of race. They

\footnotetext{
${ }^{1}$ Clinton B. Fisk to O. O. Howard, 20 July 1865, in Ira Berlin, et al., Freedom: A Documentary History of Emancipation, 1861-1867, Series I, vol. 2, The Wartime Genesis of Free Labor: The Upper South (Cambridge: Cambridge University Press, 1993), 705-7.

${ }^{2}$ Ibid., 706.
} 
believed that black freedom would result in either race war, racial equality, or a class of destitute freedmen. Finally, Kentuckians resisted emancipation because of its effects on the state's economy. From the first sign that slavery might not survive the war, they dreaded the loss of capital and the labor shortage that accompanied emancipation. In Kentucky, as in much of the rest of the South, emancipation exacerbated political and social anxieties in the postbellum era.

The social upheaval of Kentucky in the late 1860s and early 1870s grew from the state's opposition to wartime emancipation. In The Civil War and Readjustment in Kentucky, E. Merton Coulter blamed the federal government, especially the Freedmen's Bureau, for problems in the state. ${ }^{3}$ In Coulter's analysis, the Radicals in the state and their Republican allies in Washington unfairly persecuted the Democrats, Conservatives, and former Confederates, who had Kentucky's best interest in mind. Coulter failed to recognize, or willfully ignored, that conservative Kentuckians created much of the postwar unrest. Even more so than with the studies of Civil War Kentucky, scholarship on Reconstruction era Kentucky remains mired in interpretations voiced in the 1920 s. $^{4}$ As long as the Reconstruction era in Kentucky remains understudied and misunderstood, historians will be unable to grasp fully the effects of emancipation. Yet, some conclusions can be drawn. Most important, the abolition of slavery provided the catalyst

\footnotetext{
${ }^{3}$ E. Merton Coulter, The Civil War and Readjustment in Kentucky (Chapel Hill: University of North Carolina Press, 1966; reprint, Gloucester, MA: Peter Smith, 1966), especially 340-65, 411-39.

${ }^{4}$ Other than Coulter, the primary study of Kentucky during Reconstruction is Ross A. Webb, Kentucky in the Reconstruction Era (Lexington: University Press of Kentucky, 1979). While Webb's analysis was a significant improvement over Coulter, the work cannot be considered authoritative or even completely successful because of its brevity. Hambleton Tapp and James C. Klotter also wrote on the postbellum era, and like Webb, they improved the historiography, but the Reconstruction period only was only a small part of their focus; Hambleton Tapp and James C. Klotter, Kentucky: Decades of Discord, 1865-1900 (Frankfort: Kentucky Historical Society, 1977). Most general histories of Reconstruction, like most Civil War scholarship, only deal with Kentucky in passing, if at all. On the United States during Reconstruction, see Eric Foner, Reconstruction: America's Unfinished Revolution, 1863-1877 (New York: Harper \& Row, Publishers, 1988).
} 
for Kentucky's recoil from its northern allegiance. While the process was not complete until years after Appomattox, the groundwork was laid during the war. In addition, the difficulties Kentuckians had in adjusting to the end of slavery aggravated the problems of adapting to a post-war world. White Kentuckians' responses to emancipation and black enlistment during the war shaped their reaction to black freedom into the Reconstruction era and spawned violence and political power to subjugate blacks.

The cause of much of Kentucky's post-war anxiety was what historian Harold M. Hyman would have deemed a "failure of vision." The state's politicians could not envision Kentucky without slavery, and as a result, they resisted all efforts to end slavery, even once the institution had, for all practical purposes, become a dead letter. By the end of fighting, only 30 percent of Kentucky's pre-war slaves remained in bondage, but many Kentuckians would not accept a future without slaves. ${ }^{6}$ The perpetuation of slavery in the state remained an issue until it was abolished by constitutional amendment. Moreover, as historian Eric Foner argued, Kentucky lacked capable leaders who were willing to usher the state into a post-emancipation world. ${ }^{7}$ Governor Thomas E. Bramlette encouraged the General Assembly to ratify the Thirteenth Amendment, but that was a small gesture after fighting all previous emancipation policies tooth and claw. The legislature opposed any effort at abolition as did most of the state's delegation to Congress. The few Kentucky politicians who supported emancipation lacked support or and power to take the measures necessary to ease the state's transition. Likewise, few of Kentucky's newspapers made successful attempts to guide the state, despite the efforts of

\footnotetext{
${ }^{5}$ The quote comes from the title of Harold M. Hyman, Lincoln's Reconstruction: Neither Failure of Vision nor Vision of Failure (Fort Wayne, IN: Louis A. Warren Lincoln Library and Museum, 1980).

${ }^{6}$ Marion B. Lucas, A History of Blacks in Kentucky, vol. 1, From Slavery to Segregation, 1760-1891 (Frankfort: Kentucky Historical Society, 1992), 160.

${ }^{7}$ Foner, Reconstruction, 38.
} 
George D. Prentice and Henry Watterson to alleviate social difficulties in the post war era. Prentice, editor of the Louisville Journal, opposed emancipation throughout the war, but realizing that slavery was doomed, urged the state to accept the Thirteenth Amendment. ${ }^{8}$ By the end of the decade, Watterson, a Confederate veteran turned editor of the Louisville Courier-Journal, proposed a "New Departure" for the South. ${ }^{9}$ Rather than wallow in post-war misery over Confederate defeat and emancipation, Watterson urged Kentucky and the South to recognize the social and political rights of blacks as a step toward economic prosperity. Neither Prentice nor Watterson was able to direct Kentucky's postwar policy, however, and the state remained attached to the corpse of slavery. Many of the political and social leaders who could have assisted Kentuckians' adjustment to the post-war period failed the state and contributed to the continuing problems of the Reconstruction era. However, the blame also falls on common Kentuckians who would not listen to the appeals of more forward thinkers.

Emancipation and the difficulties of post-war life caused many white Kentuckians to adopt a pro-southern perspective. Parts of Kentucky remained loyal to their Union heritage longer than others. As they did during the secession crisis, Louisville and the towns across the Ohio River from Cincinnati resisted the state's pro-southern shift. Scholar Robert B. Symon, Jr., argued that Louisville's pro-southern shift came in the early 1880 s. $^{10}$ Appalachian Kentucky remained faithful to its Union past throughout the

\footnotetext{
${ }^{8}$ Tapp and Klotter, Decades of Discord, 13.

${ }^{9}$ For a description of the "New Departure" contrasted with the conservative Bourbon ideology, see ibid., 29-36. On Watterson, see Joseph Frazier Wall, Henry Watterson: Reconstructed Rebel (New York: Oxford University Press, 1956).

${ }^{10}$ Robert Bruce Symon, Jr., “'Child of the North': Louisville's Transition to a Southern City, 1879-1885” (M.A. thesis, University of Louisville, 2005). See also Anne Elizabeth Marshall, "Louisville and the Lost Cause: Memory, Identity, and the Creation of a Confederate City" (M.A. thesis, University of Georgia, 2000).
} 
postbellum era. ${ }^{11}$ However, by the end of the war, much of the rest of the state was already on the path toward embracing their Confederate veterans. However, even in those regions that praised returned Confederates, Kentuckians were pro-southern rather than pro-Confederate in sentiment. Throughout the 1860s, Kentucky retained its Unionism, even while opposing the actions of the federal government.

Kentuckians first demonstrated their allegiance to the South in the realm of politics. The major issues debated in the state elections of 1865 were the ratification of the Thirteenth Amendment and the restoration of rights to Confederate veterans. ${ }^{12}$ As a whole, Kentucky showed where its allegiance lay, electing sixty Conservatives and Democrats to the state house compared to forty Republican-sympathizing Unionists. The Conservatives also carried the state senate. Once seated, the legislators repealed the Act of Expatriation, a wartime measure that had stripped rebels of their political rights, and passed legislation guaranteeing rights to all white Kentuckians. Governor Bramlette and Colonel Frank L. Wolford were among the Unionists who supported the legislation. The reinstatement of political rights to Confederate veterans enabled them to run for office, which many soon did. In July 1867, Robert Winn, a Union veteran in Hancock County, predicted a "Confederate" victory in the upcoming elections. "To be one of the returned grays," he concluded, "is the next best thing to have been a partisan ranger during the war at home." ${ }^{\prime 3}$ Winn's forecast was correct. The 1868 Kentucky legislature was so filled with former rebels that Coulter described it as "scarcely more than the meeting of a

\footnotetext{
${ }^{11}$ Anne Elizabeth Marshall, “'A Strange Conclusion to a Triumphant War': Memory, Identity, and the Creation of a Confederate Kentucky, 1865-1925" (Ph.D. dissertation, University of Georgia, 2004), 174208.

${ }^{12}$ Tapp and Klotter, Decades of Discord, 12-3; Webb, Kentucky in the Reconstruction Era, 13-5.

${ }^{13}$ Robert Winn to Martha Cook, 25 July 1867, Winn-Cook Family Papers, The Filson Historical Society, Louisville, KY.
} 
Confederate regiment." ${ }^{14}$ However, as Ross Webb argued, these actions were more indicative of a pro-southern than a pro-Confederate stance. ${ }^{15}$ In the late 1860 s, Kentuckians believed it necessary to form a solid front in order to resist what they perceived as federal interference in state affairs.

Showing their sympathies with the South, Kentucky's congressional delegation opposed federal Reconstruction in the former Confederacy. In April 1866, Representative Burwell C. Ritter argued that since the South had surrendered, submitted to the Constitution, and accepted the provisions required for readmittance into the Union, continued Reconstruction was unnecessary. Ritter concluded, "a Government kept together by military power" would never become "a restored Union." Representative Aaron Harding echoed Ritter's opinion, arguing that the South had "returned to their allegiance, yield[ed] obedience to the Constitution and laws, and anxiously desire[d] the restoration of the Union.” As part of the reunified nation, Harding believed, the former Confederate states did not deserve to be the subject of a "political and congressional war" led by radical northerners. Harding charged that the Republicans were subverting the Constitution by denying elected southern officials seats in Congress. What resulted, Harding proclaimed, was "an oligarchy [built] on the ruins of republican government." ${ }^{, 17}$ The Kentuckians failed to prevent the passage of further Reconstruction legislation, and their sympathy with the South became so offensive to

\footnotetext{
${ }^{14}$ Coulter, The Civil War and Readjustment in Kentucky, 419.

${ }^{15}$ Webb, Kentucky in the Reconstruction Era, 15.

${ }^{16}$ Burwell C. Ritter, Free and Slave Labor, Etc.: Speech of Hon. Burwell C. Ritter, of Kentucky, In the House of Representatives, April 21, 1866 (Washington, DC: Congressional Globe Office, 1866), 1, 7.

${ }^{17}$ Aaron Harding, Restoration of the Union: Speech of Hon Aaron Harding, of Kentucky, In the House of Representatives, April 28, 1866 (Washington, DC: Congressional Globe Office, 1866), 1, 6.
} 
northern Congressmen that Massachusetts Senator Charles Sumner famously suggested that Kentucky needed to be reconstructed. ${ }^{18}$

Kentucky's resistance to emancipation during the war evolved into post-war opposition of the Freedmen's Bureau and equal rights for blacks. Many Kentuckians viewed the presence of the Freedmen's Bureau as evidence that the federal government perceived the state as part of the conquered Confederacy. ${ }^{19}$ As a result, Kentuckians felt particularly aggrieved that the bureau operated within the state. In 1866, a group of leading Unionists, including future Supreme Court Justice John Marshall Harlan, Lieutenant Governor Richard T. Jacob, and newspaper editor George D. Prentice, joined to oppose the Freedmen's Bureau in Kentucky. ${ }^{20}$ In Congress, Kentucky’s representatives and senators opposed legislation that reinforced the bureau. ${ }^{21}$ Bureau officials met with such levels of hostility and violence that some questioned whether it was worthwhile to continue operations in the state. ${ }^{22}$ Despite white resistance, the Freedmen's Bureau persevered until January 1, 1869, when all bureau branches in Kentucky, except the office in Louisville, closed.

Kentuckians also resisted the expansion of political and civil rights to blacks. In 1866, a state Democratic convention adopted resolutions condemning emancipation and

\footnotetext{
${ }^{18}$ Congressional Globe, $40^{\text {th }}$ Congress, $1^{\text {st }}$ session, Appendix, 482.

${ }^{19}$ Ross A. Webb, “"The Past is Never Dead, It's Not Even Past': Benjamin P. Runkle and the Freedmen's Bureau in Kentucky, 1866-1870," Register of the Kentucky Historical Society 84 (Autumn 1986): 346.

${ }^{20}$ Webb, "Kentucky: 'Pariah Among the Elect'," in Richard O. Curry, ed., Radicalism, Racism and Party Realignment: The Border States during Reconstruction (Baltimore: Johns Hopkins Press, 1969), 119-20. These Unionists believed, however, that Kentucky would support the rights of blacks without federal intervention.

${ }^{21}$ Congressional Globe, $39^{\text {th }}$ Congress, $1^{\text {st }}$ session, 370-72, 743-44; Congressional Globe, $39^{\text {th }}$ Congress, $1^{\text {st }}$ session, Appendix, 69-74.

${ }^{22}$ W. A. Low, "The Freedmen's Bureau in the Border States," in Richard O. Curry, ed., Radicalism, Racism and Party Realignment: The Border States during Reconstruction (Baltimore: Johns Hopkins Press, 1969), 255.
} 
equal rights for freedmen. ${ }^{23}$ While the convention accepted the end of slavery, they insisted that suffrage fell under the jurisdiction of the states as did the power to determine the rights of blacks, which, given the conservative nature of Kentucky's Democrats, meant that African Americans would receive few civil and political rights. The legislature that rejected the Thirteenth Amendment in 1865 refused to ratify the Fourteenth and Fifteenth Amendments in 1867 and 1869, respectively. ${ }^{24}$ In the U. S. Senate debate over black voting rights, Garrett Davis voiced his constituents' opinion on the matter, proclaiming "Negro suffrage is political arsenic." ${ }^{25}$ Davis argued that while the body politic could stomach a few black voters, widespread suffrage would be poisonous to the democratic system. Opposition to black rights was so widespread that in Kentucky's 1865-1866 legislative session that the state's few Republicans endorsed resolutions condemning black suffrage and supporting the removal of the army and the Freedmen's Bureau from the state. ${ }^{26}$

The violent reaction against emancipation and black enlistment also carried over into the post-war period. Throughout the state, whites, former Unionists and Confederates alike, attacked blacks in an effort to maintain political, racial, and economic superiority. ${ }^{27}$ In his 1867 annual report, O. O. Howard, head of the Freedmen's Bureau, reported that since October 1866, black Kentuckians had suffered "20 murders, 18

\footnotetext{
${ }^{23}$ Tapp and Klotter, Decades of Discord, 15.

${ }^{24}$ Webb, "Kentucky," 123-5.

${ }^{25}$ Congressional Globe, $39^{\text {th }}$ Congress, $1^{\text {st }}$ session, 246.

${ }^{26}$ Tapp and Klotter, Decades of Discord, 14.

${ }^{27}$ On Regulator violence in Kentucky, see J. Michael Crane, “"The Rebels Are Bold, Defiant, and Unscrupulous in Their Dementions of All Men': Social Violence in Daviess County, Kentucky, 18611868," Ohio Valley History 2 (Spring 2002): 17-29; J. Michael Rhyne, “We Are Mobed \& Beat': Regulator Violence Against Free Black Households in Kentucky's Bluegrass Region, 1865-1867," Ohio Valley History 2 (Spring 2002): 30-42. Ross A. Webb also discusses violence toward blacks in his article on the Freedmen's Bureau in Kentucky; Webb, “'The Past is Never Dead, It's Not Even Past'," 343-60.
} 
shootings, 11 rapes, and 270 other cases of maltreatment. ${ }^{.28}$ Additionally, in a two-year period in the late 1860s, vigilantes also burned ten freedmen's schools and blew up another. ${ }^{29}$ In October 1869, James D. Ballance, a member of the Shaker community at Pleasant Hill in Mercer County, reported that the Elders and Deacons gathered to discuss threats they had received for hiring black laborers instead of whites. At the end of the year, he wrote of one of the men hired by the Shakers being intimidated by local whites. ${ }^{30}$ In a petition to the U. S. Senate in March 1871, six men representing "the colored citizens of Frankfort and vicinity" reported 116 attacks on freedmen in the area. The committee complained that the legislature had adjourned without passing "any laws to suppress $\mathrm{Ku}$ Klux disorder." They appeal continued, "We would state that we have been law-abiding citizens, pay our taxes, and in many parts of the State our people have been driven from the polls, refused the right to vote; many have been slaughtered while attempting to vote. ${ }^{״ 1}$ The numerous incidents described by the Frankfort committee were only a fraction of similar incidents from around the state. Historian George C. Wright has argued that although less notorious, the levels of violence in Reconstruction era Kentucky reached levels similar to the Deep South. ${ }^{32}$

\footnotetext{
${ }^{28}$ Low, "The Freedmen's Bureau in the Border States," 254.

${ }^{29}$ Ibid.

${ }^{30}$ James D. Ballance Journal, 3 October 1869, 25 December 1869, Pleasant Hill Shakers Records, The Filson Historical Society, Louisville, KY.

${ }^{31}$ Memorial of a Committee Appointed at a Meeting of Colored Citizens of Frankfort, Ky., and Vicinity, Praying the Enactment of Laws for the Better Protection of Life (Washington, DC: Government Printing Office, 1871), 1. The list of attacks begins in 1867 and concludes just prior to the committee writing to the United States Senate asking for help. Coulter blamed much of the violence on the presence of the Freedman's Bureau; Coulter, The Civil War and Readjustment in Kentucky, 340-65.

${ }^{32}$ George C. Wright, Racial Violence in Kentucky, 1865-1940: Lynchings, Mob Rule, and "Legal Lynchings" (Baton Rouge: Louisiana State University Press, 1990), 19-60. On the Reconstruction era Ku Klux Klan, see Allen W. Trelease, White Terror: The Ku Klux Klan Conspiracy and Southern Reconstruction (New York: Harper \& Row, Publishers, 1971).
} 
In his study of Reconstruction, historian Eric Foner described the effect of the Civil War and emancipation as akin to a "massive earthquake."33 The conversion of millions of slaves into free people rattled white southern society to its core, and Kentucky was not exempt from the upheaval. The events of the 1860s reverberated in Kentucky well beyond the Reconstruction era. Federal emancipation policy contributed to the foundation of the pro-southern ideology that defined postbellum Kentucky. Resenting abolition as an affront to the United States Constitution, racial hierarchy, and economic security, many Kentuckians saw themselves as having more in common with the defeated South than with their wartime allies in the North. In the late-nineteenth century as the Civil War became more distant, the image of a Confederate Kentucky grew stronger. ${ }^{34}$ Erecting Confederate monuments, electing Confederate veterans, and hosting Confederate reunions were all commonplace. By the turn of the twentieth century, Kentuckians chose to ignore the state's wartime loyalty to the Union. For white Kentuckians, the legacy of emancipation meant a retreat from the Union.

\footnotetext{
${ }^{33}$ Foner, Reconstruction, 11.

${ }^{34}$ For an in-depth analysis of the Lost Cause in Kentucky, see Marshall, “"A Strange Conclusion to a Triumphant War'." For the Lost Cause in general, see Gaines M. Foster, Ghosts of the Confederacy: Defeat, the Lost Cause, and the Emergence of the New South, 1865 to 1913 (New York: Oxford University Press, 1987); David W. Blight, Race and Reunion: The Civil War in American Memory (Cambridge: Belknap Press of Harvard University Press, 2001).
} 


\section{REFERENCES}

Manuscript Collections:

Abraham Lincoln Presidential Library, Springfield, IL

Dumas Jones Papers

The Filson Historical Society, Louisville, KY

Bibb Family Papers

Blackburn Family Papers

Bodley Family Papers

Samuel J. Boldrick Papers

Orlando Brown Papers

John B. Bruner Papers

Bullitt Family Papers-Oxmoor Collection

Bush-Beauchamp Family Papers

Corps d'Afrique Papers

Dunn Family Papers

Reuben T. Durrett Papers

Fenley-Williams Family Papers

Thomas G. Gooch Papers

Jesse Root Grant Papers

Norvin Green Papers

Guthrie-Caperton Family Papers

John Henry Hammond Papers

Citizens of Hawesville Papers

Samuel Haycraft Journal

John Harding Papers

Joseph Holt Papers

Betty Howard Diary

Alexander Jeffrey Papers

Absalom Y. Johnson Diaries

Joyes Family Papers

Joyes Family Additional Papers

Kincheloe-Eskridge Family Papers

Charles Lee Emancipation Certificate

Lillard Family Papers

William Thomas McElroy Papers

Howard Miller Papers

Moxley-Offutt Family Papers

Robert A. Nelson Papers

John M. Palmer Letters 
Pettus-Speiden Family Papers

Alfred Pirtle Papers

Pleasant Hill Shakers Records

Pope-Humphrey Family Papers

Lemuel C. Porter Diary

Frank A. and Mary Savage Papers

Carl Theodore Schwartz Journal

E. Hubbard Smith Papers

E. Hubbard Smith Added Papers

E. Hubbard Smith Miscellaneous Papers

Green Clay Smith Papers

Snead Family Papers

James Speed Papers

Jacob J. Stipe Papers

Philip Tomppert Papers

Union Soldier Letters

Davy Walker Emancipation Certificate

Ward Family Papers

Watters-Curtis Family Papers

Webber-Lewis Family Papers

Lewis White Emancipation Certificate

Winn-Cook Family Papers

Winston-Jones Family Papers

Nathaniel Wolfe Papers

Kentucky Department for Libraries and Archives, Frankfort, KY

Thomas E. Bramlette Papers

James F. Robinson Papers

Kentucky Historical Society, Frankfort, KY

$55^{\text {th }}$ Kentucky Mounted Infantry Records

Coburn Family Letters

Robert H. Earnest Papers

Aaron Harding Letters

John T. Harrington Letters

Hiram Hogg Letters

Thomas F. Leech Letters

A. L. Moore Letter

Thomas Metcalfe Collection

D. C. Phillips Reconstruction Letter

Edmund A. Starling Letter

John W. Tuttle Civil War Diary

Joseph L. Verdin Letter

Wallace-Starling Family Diaries

Joseph F. Ward Slave Compensation Papers

Alfred West Papers 
Library of Congress, Washington, DC

Abraham Lincoln Papers. Available online at http://memory.loc.gov.

Manuscripts, Kentucky Library, Western Kentucky University, Bowling Green, KY

E. M. Angel Papers

Bevie Cain Letters

Calvert-Obenchain-Younglove Collection

Downing-Eubank Collection

John G. Durham Collection

Ward Bolivar Duncan Collection

W. S. Hays Collection

Knott Collection

Lewis-Starling Collection

Northcott Collection

Perkins Collection

Prentis Collection

Shaker South Union Collection

Howard and Frances Young Collection

Margaret I. King Library, University of Kentucky, Lexington, KY.

Theophilus Allen Letter

Edwin Green Bedford Papers

Benjamin F. Buckner Papers

Clay Family Papers

A. H. Colby Letters

Collins Family Papers

Cooper-Phillips Family Papers

William M. Crowley Papers

Garrett Davis Letter

Catherine and Howard Evans Papers

Gunn Family Papers

John W. Jones Papers

Moore Family Papers

H. G. Rich Letter

Starling Family letters

Slave Compensation forms

Smith Family Papers

U. S. Army General Orders, No. 26

National Archives and Records Administration, Washington, DC

American Freedman's Inquiry, Testimony taken in Kentucky, Tennessee, and

Missouri, Letters Received by the Office of the Adjutant General (Main Series), 1861-1870, Record Group 94 (microfilm) 
Perkins Library, Duke University, Durham, NC Stephen Gano Burbridge Papers

Private Collection of Christy Bennett, Cecilia, KY

Hardy U. Jaggers Papers

Newspapers:

Covington Journal, 1861-1862

Louisville Daily Union Press, 1864

Louisville Democrat, 1865

Louisville Evening Bulletin, 1862

Louisville Weekly Journal, 1861-1865

Paris (Ky.) Western Citizen, 1861

Government documents:

The Acts of the General Assembly of the Commonwealth of Kentucky, 1861-1865

Congressional Globe, 1861-1867

Eighth Census of the United States, 1860

The Journal of the House of Representatives of the Commonwealth of Kentucky, 18611865

The Journal of the Senate of the Commonwealth of Kentucky, 1861-1865

War of the Rebellion: A Compilation of the Official Records of the Union and Confederate Armies. 128 volumes. Washington, D.C.: Government Printing Office, 1880-1901.

Pamphlets:

Grider, Henry. Speech of Hon. Henry Grider, of Kentucky, on the Bills to Confiscate the Property and Free from Servitude the Slaves of Rebels; Delivered in the House of Representatives, May 22, 1862. Washington, DC: Congressional Globe Office, 1862.

- - -. Speech of Hon. Henry Grider, of Kentucky, on Reconstruction; Delivered in the House of Representatives, March 24, 1866. Washington, DC: Congressional Globe Office, 1866.

Harding, Aaron. Speech of Hon. A. Harding, of Kentucky, In the House of Representatives, December 17, 1861. Washington, DC: Scammell \& Co. Printers, [1861].

- - -. Restoration of the Union: Speech of Hon Aaron Harding, of Kentucky, In the House of Representatives, April 28, 1866. Washington, DC: Congressional Globe Office, 1866. 
Memorial of a Committee Appointed at a Meeting of Colored Citizens of Frankfort, Ky., and Vicinity, Praying the Enactment of Laws for the Better Protection of Life. Washington, DC: Government Printing Office, 1871.

Ritter, Burwell C. Free and Slave Labor, Etc.: Speech of Hon. Burwell C. Ritter, of Kentucky, In the House of Representatives, April 21, 1866. Washington, DC: Congressional Globe Office, 1866.

Wickliffe, Charles A. Speech of Hon C. A. Wickliffe, of Kentucky, on the Following Resolution: Resolved, That the United States ought to co-operate with any State which may adopt gradual abolishment of slavery, giving to such State pecuniary aid, to be used by such State in its discretion, to compensate for the inconvenience, public and private, produced by such change of system, Delivered in the House of Representatives, March 11, 1862. Washington, DC: L. Towers \& Co., 1862.

Wolford, Frank L. Col. Wolford's Letter to President Lincoln. [Liberty, KY]: Casey County News, 1966.

Yeaman, George H. Speech of Hon. Geo. H. Yeaman, of Kentucky, on the President's Emancipation Proclamation, Delivered in the House of Representatives, December 18, 1862. Baltimore: J. Murphy, 1863.

Books:

Abbott, Richard H. The Republican Party and the South, 1855-1877: The First Southern Strategy. Chapel Hill: University of North Carolina Press, 1986.

Aron, Stephen. How the West Was Lost: The Transformation of Kentucky from Daniel Boone to Henry Clay. Baltimore: Johns Hopkins Press, 1996.

Ash, Stephen V. Middle Tennessee Society Transformed, 1860-1870: War and Peace in the Upper South. Baton Rouge: Louisiana State University Press, 1988.

- - - When the Yankees Came: Chaos and Conflict in the Occupied South, 1861-1865. Chapel Hill: University of North Carolina Press, 1995.

Bailey, Anne J. Invisible Southerners: Ethnicity in the Civil War. Athens: University of Georgia Press, 2006.

Baker, Jean H. Affairs of Party: The Political Culture of Northern Democrats in the MidNineteenth Century. Ithaca, NY: Cornell University Press, 1983.

Basler, Roy P., ed. The Collected Works of Abraham Lincoln. 8 volumes. New Brunswick, NJ: Rutgers University Press, 1953. 
Belz, Herman. Reconstructing the Union: Theory and Policy during the Civil War. Ithaca, NY: Cornell University Press for the American Historical Association, 1969.

- - -. Emancipation and Equal Rights: Politics and Constitutionalism in the Civil War Era. New York: W. W. Norton \& Company, 1978.

- - -. Abraham Lincoln, Constitutionalism, and Equal Rights in the Civil War Era. New York: Fordham University Press, 1998.

Berlin, Ira. Many Thousands Gone: The First Two Centuries of Slavery in North America. Cambridge, MA: Belknap Press of Harvard University Press, 1998.

Berlin, Ira, Barbara J. Fields, Steven F. Miller, Joseph P. Reidy, and Leslie S. Rowland. Slaves No More: Three Essays on Emancipation and the Civil War. Cambridge: Cambridge University Press, 1992.

Berlin, Ira, Barbara J. Fields, Thavolia Glymph, Joseph P. Reidy, and Leslie S. Rowland, eds. Freedom: A Documentary History of Emancipation, 1861-1867. Series I, vol. 1. The Destruction of Slavery. Cambridge: Cambridge University Press, 1985.

Berlin, Ira, Steven F. Miller, Joseph P. Reidy, and Leslie S. Rowland, eds. Freedom: A Documentary History of Emancipation, 1861-1867. Series I, vol. 2. The Wartime Genesis of Free Labor: The Upper South. Cambridge: Cambridge University Press, 1993.

Berlin, Ira, Joseph P. Reidy, and Leslie S. Rowland, eds. Freedom: A Documentary History of Emancipation, 1861-1867. Series II. The Black Military Experience. Cambridge: Cambridge University Press, 1982.

Bigham, Darrel E. On Jordan's Banks: Emancipation and Its Aftermath in the Ohio River Valley (Lexington: University Press of Kentucky, 2006).

Blight, David W. Race and Reunion: The Civil War in American Memory. Cambridge: Belknap Press of Harvard University Press, 2001.

Blight, David W. and Brooks D. Simpson. Union \& Emancipation: Essays on Politics and Race in the Civil War Era. Kent, OH: Kent State University Press, 1997.

Burgess, John W. The Civil War and the Constitution, 1859-1865. 2 vols. New York: Charles Scribner's Sons, 1901.

Burlingame, Michael and John R. Turner Ettlinger, eds. Inside Lincoln's White House: The Complete Civil War Diary of John Hay. Carbondale: Southern Illinois University Press, 1997. 
Carwardine, Richard. Lincoln: A Life of Purpose and Power. New York: Alfred A. Knopf, 2006.

Cimbala, Paul A. and Randall M. Miller, eds. An Uncommon Time: The Civil War and the Northern Home Front. New York: Fordham University Press, 2002.

Cimprich, John. Slavery's End in Tennessee, 1861-1865. University, AL: University of Alabama Press, 1985.

Clark, Thomas D. A History of Kentucky. New York: Prentice-Hall, 1937

- - -. Agrarian Kentucky. Lexington: University Press of Kentucky, 1977.

Coleman, J. Winston, Jr., Slavery Times in Kentucky. Chapel Hill: University of North Carolina Press, 1940.

Collins, Lewis and Richard H. Collins' Historical Sketches of Kentucky. 2 vols. Covington, KY: Collins \& Co., 1874. Reprint, Louisville: John P. Morton \& Co., 1924.

Cooling, Benjamin Franklin. Fort Donelson's Legacy: War and Society in Kentucky and Tennessee, 1861-1865. Knoxville: University of Tennessee Press, 1997.

Cornish, Dudley Taylor. The Sable Arm: Negro Troops in the Union Army, 1861-1865. New York: Longmans, Green, \& Co., 1956.

Coulter, E. Merton. The Civil War and Readjustment in Kentucky. Chapel Hill: University of North Carolina Press, 1926. Reprint, Gloucester, MA: Peter Smith, 1966.

Cox, LaWanda. Lincoln and Black Freedom: A Study in Presidential Leadership. Columbia: University of South Carolina Press, 1981.

Curry, Richard O., ed. Radicalism, Racism, and Party Realignment: The Border States during Reconstruction. Baltimore: Johns Hopkins Press, 1969.

Crofts, Daniel W. Reluctant Confederates: Upper South Unionists in the Secession Crisis. Chapel Hill: University of North Carolina Press, 1989.

Davis, David Brion. Inhuman Bondage: The Rise and Fall of Slavery in the New World. New York: Oxford University Press, 2006.

Donald, David Hebert. Lincoln. New York: Simon \& Schuster, 1995. 
Du Bois, W. E. Burghardt. Black Reconstruction: An Essay Toward a History of the Part which Black Folk Played in the Attempt to Reconstruct Democracy in America, 1860-1880. New York: Russell \& Russell, 1935.

Ely, James W., Jr. The Guardian of Every Other Right: A Constitutional History of Property Rights. $2^{\text {nd }}$ ed. New York: Oxford University Press, 1998.

Essah, Patience. A House Divided: Slavery and Emancipation in Delaware, 1638-1865. Charlottesville: University of Virginia Press, 1996.

Federalism as a Democratic Process: Essays by Roscoe Pound, Charles H. McIlwain, Roy F. Nichols. New Brunswick, NJ: Rutgers University Press, 1942.

Fehrenbacher, Don E. The Slaveholding Republic: An Account of the United States Government's Relations to Slavery. Edited by Ward M. McAfee. New York: Oxford University Press, 2001.

Fields, Barbara Jeanne. Slavery and Freedom on the Middle Ground: Maryland During the Nineteenth Century. New Haven: Yale University Press, 1985.

Fisher, Noel C. War at Every Door: Partisan Politics and Guerrilla Violence in East Tennessee, 1860-1869. Chapel Hill: University of North Carolina Press, 1997.

Foner, Eric. Nothing but Freedom: Emancipation and Its Legacy. Baton Rouge: Louisiana State University Press, 1983.

- - . Reconstruction: America's Unfinished Revolution, 1863-1877. New York: Harper \& Row, Publishers, 1988.

Foster, Gaines M. Ghosts of the Confederacy: Defeat, the Lost Cause, and the Emergence of the New South, 1865 to 1913. New York: Oxford University Press, 1987.

Fredrickson, George M. The Black Image in the White Mind: The Debate on AfroAmerican Character and Destiny, 1817-1914. New York: Harper \& Row, Publishers, 1971. Reprint, Middletown, CT: Wesleyan University Press, 1987.

Freehling, William W. The Road to Disunion. Volume 1. Secessionists at Bay, 17761854. New York: Oxford University Press, 1990.

- - -. The South vs. the South: How Anti-Confederate Southerners Changed the Course of the Civil War. New York: Oxford University Press, 2001.

Gates, Paul W. Agriculture and the Civil War. New York: Alfred A. Knopf, 1965. 
Genovese, Eugene D. The World the Slaveholders Made: Two Essays in Interpretation. New York: Pantheon Books, 1969.

Glatthaar, Joseph T. Forged in Battle: The Civil War Alliance of Black Soldiers and White Officers. New York: Free Press, 1990.

Goodwin, Doris Kearns. Team of Rivals: The Political Genius of Abraham Lincoln. New York: Simon \& Schuster, 2005.

Gray, Lewis Cecil. History of Agriculture in the Southern United States to 1860. 2 volumes. Washington, DC: Carnegie Institution of Washington, 1933. Reprint, New York: Peter Smith, 1941.

Guelzo, Allen C. Lincoln's Emancipation Proclamation: The End of Slavery in America. New York: Simon \& Schuster, 2004.

Harrison, Lowell H. The Civil War in Kentucky. Lexington: University Press of Kentucky, 1975.

- - -. The Antislavery Movement in Kentucky. Lexington: University Press of Kentucky, 1978.

- - -. Lincoln of Kentucky. Lexington: University Press of Kentucky, 2001.

Harrison, Lowell and James C. Klotter. A New History of Kentucky. Lexington: University Press of Kentucky, 1997.

Harrold, Stanley. The Abolitionists and the South, 1831-1861. Lexington: University Press of Kentucky, 1995.

Howard, Victor B. Black Liberation in Kentucky: Emancipation and Freedom, 18621884. Lexington: University Press of Kentucky, 1983.

Hunt, Alfred N. Haiti's Influence on Antebellum America: Slumbering Volcano in the Caribbean. Baton Rouge: Louisiana State University Press, 1988.

Hurt, R. Douglas. Agriculture and Slavery in Missouri's Little Dixie. Columbia: University of Missouri Press, 1992.

Huston, James L. Calculating the Value of the Union: Slavery, Property Rights, and the Economic Origins of the Civil War. Chapel Hill: University of North Carolina Press, 2003.

Hyman, Harold M. A More Perfect Union: The Impact of the Civil War and Reconstruction on the Constitution. New York: Alfred A. Knopf, 1973. 
- - -. Lincoln's Reconstruction: Neither Failure of Vision nor Vision of Failure. Fort Wayne, IN: Louis A. Warren Lincoln Library and Museum, 1980.

Hyman, Harold M. and William M. Wiecek. Equal Justice Under Law: Constitutional Development, 1833-1875. New York: Harper \& Row, Publishers, 1982.

Jordan, Winthrop D. White Over Black: American Attitudes Toward the Negro, 15501812. Chapel Hill: University of North Carolina Press for the Institute of Early American History and Culture, 1968.

Kammen, Michael. A Machine that Would Go of Itself: The Constitution in American Culture. New York: Alfred A. Knopf, 1986.

Klotter, James C. The Breckinridges of Kentucky, 1760-1981. Lexington: University Press of Kentucky, 1986.

Litwack, Leon F. North of Slavery: The Negro in the Free States, 1790-1860. Chicago: University of Chicago Press, 1961.

- - -. Been in the Storm So Long: The Aftermath of Slavery. New York: Vintage Books, 1980.

Lucas, Marion B. A History of Blacks in Kentucky. Volume 1. From Slavery to Segregation, 1760-1891. Frankfort: Kentucky Historical Society, 1992.

Martin, Jonathan D. Divided Mastery: Slave Hiring in the American South. Cambridge, MA: Harvard University Press, 2004.

McDowell, Robert Emmett. City of Conflict: Louisville in the Civil War, 1861-1865. Louisville: Louisville Civil War Round Table Publishers, 1962.

McGlynn, Frank and Seymour Drescher, eds. The Meaning of Freedom: Economics, Politics, and Culture After Slavery. Pittsburgh: University of Pittsburgh Press, 1992.

McKnight, Brian D. Contested Borderland: The Civil War in Appalachian Kentucky and Virginia. Lexington: University Press of Kentucky, 2006.

McPherson, James M. The Battle Cry of Freedom: The Civil War Era. New York: Oxford University Press, 1988. Paperback, New York: Ballantine Books, 1989.

- - -. Abraham Lincoln and the Second American Revolution. New York: Oxford University Press, 1991.

- -. For Cause and Comrades: Why Men Fought the Civil War. New York: Oxford University Press, 1997. 
Neal, Mary Julia, ed. The Journal of Eldress Nancy: Kept at the South Union, Kentucky, Shaker Colony, August 15, 1861-September 4, 1864. Nashville, TN: Parthenon Press, 1963.

Nedelsky, Jennifer. Private Property and the Limits of American Constitutionalism: The Madisonian Framework and Its Legacy. Chicago: University of Chicago Press, 1990.

Neely, Mark E., Jr. The Fate of Liberty: Abraham Lincoln and Civil Liberties. New York: Oxford University Press, 1991.

- - -. The Union Divided: Party Conflict in the Civil War North. Cambridge: Harvard University Press, 2002.

Oates, Stephen B. To Purge this Land with Blood: A Biography of John Brown. $2^{\text {nd }}$ edition. Amherst: University of Massachusetts Press, 1984.

- - -. With Malice Toward None: A Life of Abraham Lincoln. New York: Harper \& Row, 1977. Paperback, HarperPerennial, 1994.

Palmer, George Thomas. A Conscientious Turncoat: The Story of John M. Palmer, 18171900. New Haven: Yale University Press, 1941.

Paludan, Phillip Shaw. A Covenant with Death: The Constitution, Law and Equality in the Civil War Era. Urbana: University of Illinois Press, 1975.

- - -. “A People's Contest”: The Union and Civil War, 1861-1865. New York: Harper \& Row, Publishers, 1988.

Perman, Michael. Emancipation and Reconstruction. $2^{\text {nd }}$ ed. Wheeling, IL: Harlan Davidson, 2003.

Potter, David M. The Impending Crisis, 1848-1861. Edited by Don E. Fehrenbacher. New York: Harper \& Row, 1976. Paperback, HarperPerennial, 1976.

Przybyszewski, Linda. The Republic According to John Marshall Harlan. Chapel Hill: University of North Carolina Press, 1999.

Quarles, Benjamin. Lincoln and the Negro. New York: Oxford University Press, 1962.

Randall, J. G. Constitutional Problems Under Lincoln. Revised edition. Urbana: University of Illinois Press, 1951. Reprint, Gloucester, MA: Peter Smith, 1963.

Ransom, Roger L. Conflict and Compromise: The Political Economy of Slavery, Emancipation, and the American Civil War. Cambridge: Cambridge University Press, 1989. 
Sears, Richard D., ed. Camp Nelson, Kentucky: A Civil War History. Lexington: University Press of Kentucky, 2002.

Shaler, N. S. Kentucky: A Pioneer Commonwealth. Boston: Houghton Mifflin Co., 1884.

Silbey, Joel H. A Respectable Minority: The Democratic Party in the Civil War Era, 1860-1868. New York: Norton, 1977.

Smith, Edward Conrad. The Borderland in the Civil War. New York: The Macmillan Company, 1927.

Smith, John David, ed. Black Soldiers in Blue: African American Troops in the Civil War Era. Chapel Hill: University of North Carolina Press, 2002.

Smith, John David and William Cooper, Jr., eds. A Union Woman in Civil War Kentucky: The Diary of Frances Peter. Lexington: University Press of Kentucky, 2000.

Smith, Z. F. The History of Kentucky: From Its Earliest Discovery and Settlement, to the Present Date. Louisville: Courier-Journal Job Printing Co., 1886.

Siddali, Silvana R. From Property to Person: Slavery and the Confiscation Acts, 18611862. Baton Rouge: Louisiana State University Press, 2005.

Speed, Thomas. The Union Cause in Kentucky, 1860-1865. New York: G.B. Putnam's Sons, 1907.

Syrett, John. The Civil War Reconstruction Acts: Failing to Reconstruct the South. New York: Fordham University Press, 2005.

Tallant, Harold D. Evil Necessity: Slavery and Political Culture in Antebellum Kentucky. Lexington: University Press of Kentucky, 2003.

Tapp, Hambleton and James C. Klotter. Kentucky: Decades of Discord, 1865-1900. Frankfort: Kentucky Historical Society, 1977.

Taylor, Amy Murrell. The Divided Family in Civil War America. Chapel Hill: University of North Carolina Press, 2005.

Trelease, Allen W. White Terror: The Ku Klux Klan Conspiracy and Southern Reconstruction. New York: Harper \& Row, Publishers, 1971.

Voegeli, V. Jacque. Free but Not Equal: The Midwest and the Negro During the Civil War. Chicago: University of Chicago Press, 1967. 
Vorenberg, Michael. Final Freedom: The Civil War, the Abolition of Slavery, and the Thirteenth Amendment. Cambridge: Cambridge University Press, 2001.

Wagant, Charles Lewis. The Mighty Revolution: Negro Emancipation in Maryland, 1862-1864. Baltimore: The Johns Hopkins Press, 1964.

Wall, Joseph Frazier. Henry Watterson: Reconstructed Rebel. New York: Oxford University Press, 1956.

Webb, Ross A. Benjamin Helm Bristow: Border State Politician. Lexington: University Press of Kentucky, 1969.

- - -. Kentucky in the Reconstruction Era. Lexington: University Press of Kentucky, 1978.

Williamson, Joel. The Crucible of Race: Black-White Relations in the American South Since Emancipation. New York: Oxford University Press, 1984.

Wilson, Henry. History of the Antislavery Measures of the Thirty-Seventh and ThirtyEighth United-States Congresses, 1861-1864. Boston: Walker, Wise, and Company, 1864.

Wood, Forrest G. Black Scare: The Racist Response to Emancipation and Reconstruction. Berkeley: University of California Press, 1969.

Wright, Gavin. Slavery and American Economic Development. Baton Rouge: Louisiana State University Press, 2006.

Wright, George C. Racial Violence in Kentucky, 1865-1940: Lynchings, Mob Rule, and “Legal Lynchings”. Baton Rouge: Louisiana State University Press, 1990.

Wyatt-Brown, Bertram. Southern Honor: Ethics and Behavior in the Old South. New York: Oxford University Press, 1982.

Articles:

Bartman, Roger J. "Joseph Holt and Kentucky in the Civil War." Filson Club History Quarterly 40 (April 1966): 105-22.

Bearman, Alan. "“The South Carolina of Kentucky': Religion and Secession in the Jackson Purchase.” Filson History Quarterly 76 (Fall 2002): 495-521.

Blassingame, John W. "The Recruitment of Colored Troops in Kentucky, Maryland, and Missouri, 1863-1865." The Historian 29 (August 1967): 533-45. 
Crane, J. Michael. “"The Rebels Are Bold, Defiant, and Unscrupulous in Their Dementions of All Men': Social Violence in Daviess County, Kentucky, 18611868." Ohio Valley History 2 (Spring 2002): 17-29.

De Falaise, Louis. "General Stephen Gano Burbridge's Command in Kentucky," Register of the Kentucky Historical Society 69 (April 1971): 101-27.

Flannery, Michael A. "Kentucky History Revisited: The Role of the Civil War in Shaping Kentucky's Collective Consciousness." Filson Club History Quarterly 71 (January 1997): 27-51.

Fliss, William M. 'Wisconsin's 'Abolition Regiment': The Twenty-Second Volunteer Infantry in Kentucky, 1862-1863." Wisconsin Magazine of History 86 (Winter 2002-2003): 2-17.

Gienapp, William E. "Abraham Lincoln and the Border States." Journal of the Abraham Lincoln Association. 13 (1992): 13-46.

Gilliam, Will D., Jr. "Robert J. Breckinridge: Kentucky Unionist.” Register of the Kentucky Historical Society 69 (October 1971): 362-85.

Harrison, Lowell H. "The Civil War in Kentucky: Some Persistent Questions." Register of the Kentucky Historical Society 76 (January 1978): 1-21.

Hawkins, Susan. "The African American Experience at Forts Henry, Heiman, and Donelson, 1862-1867.” Tennessee Historical Quarterly 61 (Winter 2002): 22241.

Hood, James Larry. "For the Union: Kentucky's Unconditional Unionist Congressmen and the Development of the Republican Party in Kentucky, 1863-1865." Register of the Kentucky Historical Society 76 (July 1978): 197-215.

Howard, Victor B. "Lincoln Slave Policy in Kentucky: A Study of Pragmatic Strategy." Register of the Kentucky Historical Society 80 (Summer 1982): 281-308.

- - -. "The Civil War in Kentucky: The Slave Claims His Freedom." Journal of Negro History 67 (Autumn 1982): 245-56.

Kelly, Jack. "John J. Crittenden and the Constitutional Union Party." Filson Club History Quarterly 48 (July 1974): 265-276.

Lee, Jacob F. “'Between Two Fires': Cassius M. Clay, Slavery and Antislavery in the Kentucky Borderlands." Ohio Valley History 6 (Fall 2006): 50-70. 
Lucas, Marion B. "Camp Nelson, Kentucky, During the Civil War: Cradle of Liberty or Refugee Death Camp?" Filson Club History Quarterly 63 (October 1989): 43952.

- - -. "Kentucky Blacks: The Transition from Slavery to Freedom." Register of the Kentucky Historical Society 91 (Autumn 1993): 403-19.

Murphy, James B. "Slavery and Freedom in Appalachia: Kentucky as a Demographic Case Study." Register of the Kentucky Historical Society 80 (Spring 1982): 15169.

Rhyne, J. Michael. “'We Are Mobed \& Beat': Regulator Violence Against Free Black Households in Kentucky's Bluegrass Region, 1865-1867." Ohio Valley History 2 (Spring 2002): 30-42.

- - -. “A 'Murderous Affair in Lincoln County': Politics, Violence and Memory in a Civil War Era Community." American Nineteenth Century History 7 (September 2006): 337-59.

Sears, Richard. "John G. Fee, Camp Nelson, and Kentucky Blacks, 1864-1865." Register of the Kentucky Historical Society 85 (Spring 1987): 29-45.

Smith, John David. "The Recruitment of Negro Soldiers in Kentucky, 1863-1865." Register of the Kentucky Historical Society 72 (October 1974): 364-90.

- - -. 'E. Merton Coulter, the 'Dunning School,' and The Civil War and Readjustment in Kentucky." Register of the Kentucky Historical Society 86 (Spring 1988): 52-69.

Smith, Krista. "Slaveholders vs. Slaveholders: Divided Kentuckians in the Secession Crisis." Register of the Kentucky Historical Society 97 (Autumn 1999): 375-401.

Tapp, Hambleton. "Incidents in the Life of Frank Wolford, Colonel of the First Kentucky Union Cavalry." Filson Club History Quarterly 10 (April 1936): 8299.

Webb, Ross A. “"The Past is Never Dead, It's Not Even Past': Benjamin P. Runkle and the Freedmen's Bureau in Kentucky, 1866-1870." Register of the Kentucky Historical Society 84 (Autumn 1986): 343-60.

Williams, Gary L. "Lincoln's Neutral Allies: The Case of Kentucky Unionists." South Atlantic Quarterly 73 (Winter 1974): 70-84.

Williams, Kenneth H. and James Russell Harris, eds. "Kentucky in 1860: A Statistical Overview." Register of the Kentucky Historical Society 103 (Autumn 2005): 74364. 
Yonkers, Charles E. "The Civil War Transformation of George W. Smith: How a Western Kentucky Farmer Evolved from Unionist Whig to Pro-Southern Democrat." Register of the Kentucky Historical Society 103 (Autumn 2005): 661690.

Unpublished dissertations and theses:

Alexander, Ronald R. "Central Kentucky During the Civil War, 1861-1865." Ph.D. dissertation, University of Kentucky, 1976.

Cole, Jennifer M. "Semper Eadem: An Interpretation of the Life and Career of James Speed.” M.A. thesis, University of Louisville, 2003.

Manning, John W. "Reconstruction in Kentucky." M.A. thesis, University of Louisville, 1926.

- - -. "Louisville and the Lost Cause: Memory, Identity, and the Creation of a Confederate City." M.A. thesis, University of Georgia, 2000.

Marshall, Anne Elizabeth. "'A Strange Conclusion to a Triumphant War': Memory, Identity, and the Creation of a Confederate Kentucky, 1865-1925." Ph.D. dissertation, University of Georgia, 2005.

Owen, Thomas Louis. “The Pre-Court Career of John Marshall Harlan.” M.A. thesis, University of Louisville, 1970.

Paine, Christopher M. “'Kentucky Will Be the Last to Give Up the Union': Kentucky Politics, 1844-1861." Ph.D. dissertation, University of Kentucky, 1998.

Rockenbach, Stephen I. “'War upon our border': War and Society in Two Ohio Valley Communities, 1861-1865.” Ph.D. dissertation, University of Cincinnati, 2005.

Russell, Timothy McKnight. "Neutrality and Ideological Conflict in Kentucky during the First Year of the American Civil War." Ph.D. dissertation, University of New Mexico, 1989.

Simpson, Patricia Hoskins. “'When Will the Measure of Woe be Complete?': Ellen McGaughey Wallace: Life as a Kentucky Slave Mistress.” M.A. thesis, Eastern Kentucky University, 2001.

Symon, Robert Bruce, Jr. "“Child of the North': Louisville's Transition to a Southern City, 1879-1885.” M.A. Thesis, University of Louisville, 2005.

Volz, Harry August, III. "Party, State, and Nation: Kentucky and the Coming of the American Civil War.” Ph.D. dissertation, University of Virginia, 1982. 


\section{CURRICULUM VITAE}

NAME: Jacob F. Lee

ADDRESS: The Filson Historical Society

1310 S. Third St.

Louisville, KY 40208

DOB: $\quad$ Elizabethtown, Kentucky - December 23, 1982

EDUCATION :

B.A., History, minor in English

University of Louisville

2001-2005

M.A., History

University of Louisville

2005-2007

AWARDS \& PRIZES:

Best Paper on Kentucky History at the $200615^{\text {th }}$ Annual Bluegrass Symposium for “'Between Two Fires': Cassius M. Clay, Slavery, and Antislavery in the Kentucky Borderlands"

Best Graduate Paper at the 2006 Kentucky Regional Phi Alpha Theta Student History Conference for "Colonel Reuben T. Durrett, the Filson Club and Historical Memory in Postbellum Kentucky"

2006-07 Thomas Hamilton Graduate Scholarship in U.S. History, University of Louisville Department of History

2006-07 Jurdem Graduate Scholarship in U.S. History, University of Louisville Department of History

2005-06 Filson Historical Society Internship, University of Louisville Department of History

2001-05 Trustees' Scholarship, University of Louisville

\section{WORK EXPERIENCE:}

Special Collections Assistant, Filson Historical Society

August 2006 - present

Manuscript Cataloger, Filson Historical Society

August 2005 - August 2006 
Filson Intern, Filson Historical Society

August 2005 - May 2006

H. F. Boehl Summer Intern, Filson Historical Society

May 2005 - August 2005

Michael N. Harreld Intern, Filson Historical Society

January 2005 - May 2005

REFEREED PUBLICATIONS:

"'Between Two Fires': Cassius M. Clay, Slavery, and Antislavery in the

Kentucky Borderlands," Ohio Valley History 6 (Fall 2006): 50-70.

OTHER PUBLICATIONS:

Review of Uncivil War: Five New Orleans Street Battles and the Rise and Fall of

Radical Reconstruction by James K. Hogue, Southern Historian

(forthcoming)

"Humphrey Marshall Papers at the Filson Historical Society," Ohio Valley

History 7 (Spring 2007): 63-68.

"Humphrey Marshall in China," The Filson 7 (Spring 2007): 6-7.

"Browsing in Our Archives: John G. Fee and Abolitionism in Kentucky," The

Filson 6 (Fall 2006): 2-3.

"Reuben T. Durrett Papers at the Filson Historical Society," Ohio Valley History

6 (Summer 2006): 54-8.

Review of General Tyree H. Bell, CSA: Forrest's Fighting Lieutenant by

Nathaniel Cheairs Hughes, Jr. with Connie Walton Moretti and James

Michael Brown, Southern Historian 27 (Spring 2006): 87-8.

"American Legion, Jefferson Post \#15 Records," The Filson 6 (Winter 2006): 1214.

“Frances Ingram Papers, 1894-1953,” The Filson 5 (Summer 2005): 8-11.

\section{CONFERENCE PAPERS:}

"Emancipation and Unionism in Civil War Kentucky," presented at the Ohio Valley History Conference, October 20, 2006.

“"Between Two Fires:' Cassius M. Clay, Slavery and Antislavery in the Kentucky Borderlands," presented at the $15^{\text {th }}$ Annual Bluegrass Symposium, April 8, 2006.

"Colonel Reuben T. Durrett, the Filson Club and Historical Memory in Postbellum Kentucky," presented at the Kentucky Regional Phi Alpha Theta Student History Conference, April 1, 2006.

"“And the Knife to the Hilt': Guerrilla Warfare in Missouri, 1854-1876," presented at the Kentucky Regional Phi Alpha Theta Student History Conference, April 2, 2005. 
"'And the Knife to the Hilt': Guerrilla Warfare in Missouri, 1854-1876," presented at the Kentucky Honors Roundtable, February 26, 2005.

"Electrification and the Transformation of Rural America," presented at the Kentucky Regional Phi Alpha Theta Student History Conference, April 3, 2004.

PROFESSIONAL AND HONORS ORGANIZATIONS:

Organization of American Historians

Southern Historical Association

Filson Historical Society

Kentucky Historical Society

Phi Alpha Theta, International History Honors Society

-President, Nu Xi Chapter, 2005-2006

Society for American Baseball Research 